مجلة كلية التربية، جامعة الأزهر ، العدد: (183، الجزء الثاني) يوليو لسنة 2019م

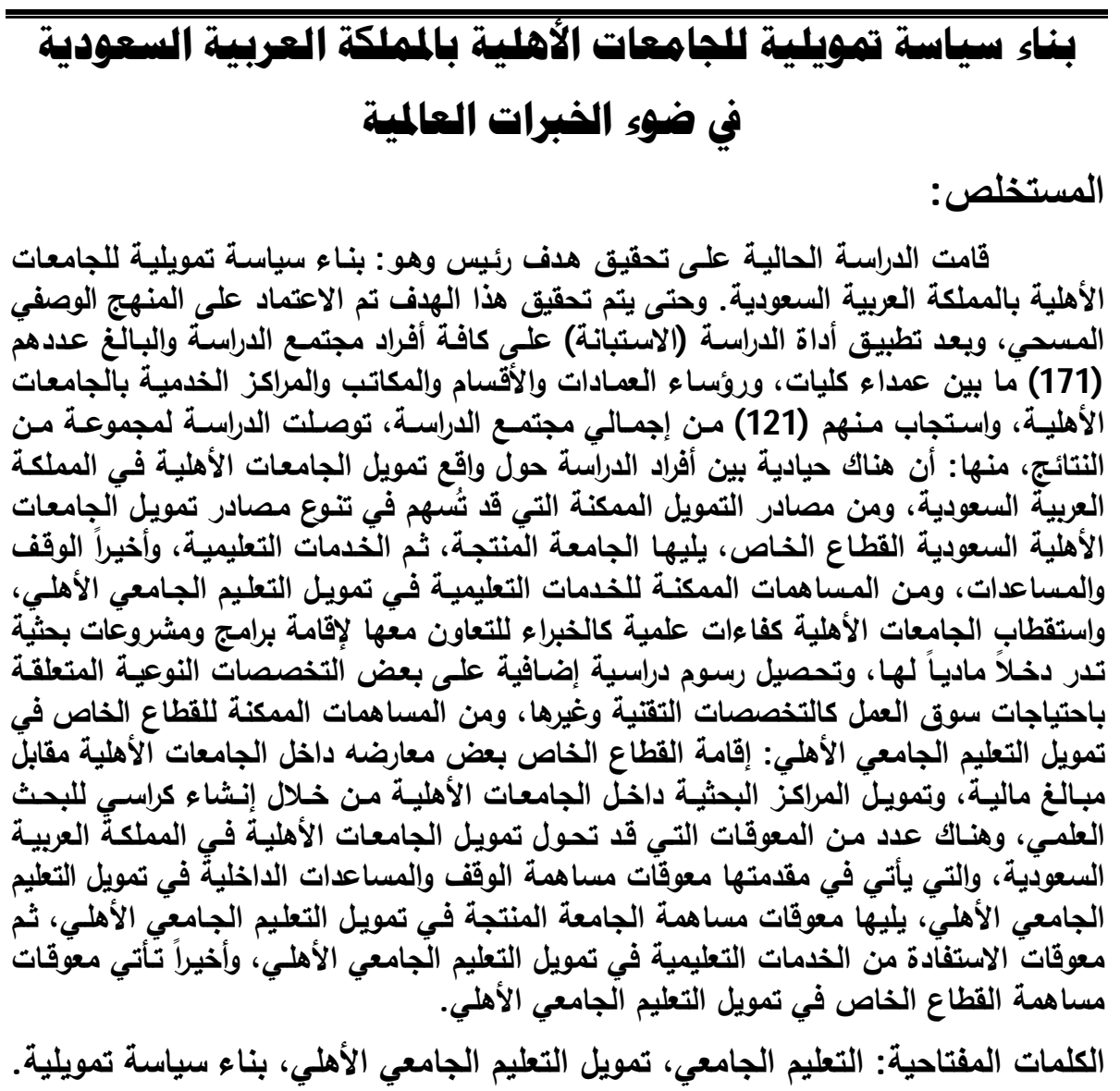

Abstract:

Building A Funding Policy for The Private Universities in The Kingdom of Saudi Arabia in The Light of International Experiences

The current study aimed to achieve the following main objective is: build a financing policy for private universities in the Kingdom of Saudi Arabia based on international experiences. In order to achieve this objective, the descriptive survey method is applied. After applying the tool of the study (Questionnaire) to all members of the study population, who are (171) between Deans of colleges, heads of Deanships, departments, offices, and service centers in the private universities, (121) of the total study population. The study revealed the following main results: That There is neutrality between the members of the study about the reality of financing private universities in the Kingdom of Saudi Arabia. And The private sector is the first possible source of financing that may contribute to the diversification of the 
financing sources of the private universities in the Kingdom of Saudi Arabia, followed by the productive university, the educational services, and finally endowment and assistance. And The possible contributions of educational services to financing the private university education including that the private universities should recruit scientific competencies such as experts to collaborate with them to establish programs and research projects that generate financial income, and to collect additional tuition fees on some specific majors related to the needs of the labor market such as technical and other programs. And The possible contributions of the private sector to finance the private university education that the private sector: should establish some exhibitions within the private universities against amounts, And finance research centers within the national universities through establishing scientific research chairs. There are barriers may prevent financing private universities in the Kingdom of Saudi Arabia. Firstly, the impediments to the contributions of endowment and internal assistance in financing the private university education, followed by the barriers of the contribution of the productive university in financing the private university education, and then obstacles to benefit from educational services in financing the university education, and finally the impediments of the private sector contribution to finance the private university education.

Keywords: University education, Funding for university education, Building a financing policy.

يؤكد الواقع الفعلي أن الجامعات المرموقة والمتفوقة أو الساعية نحو التفوق في

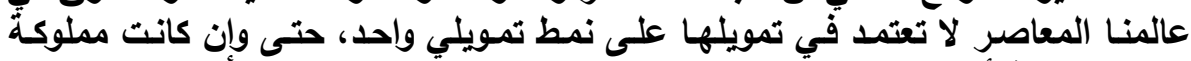

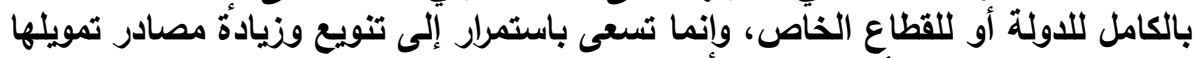

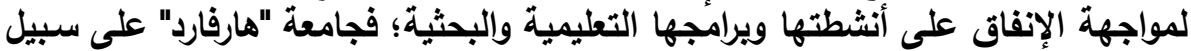

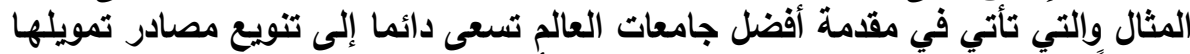

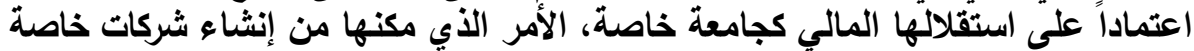

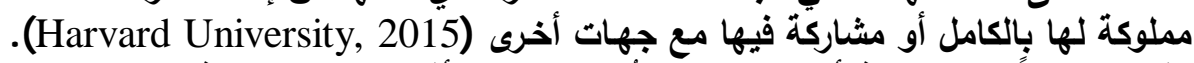

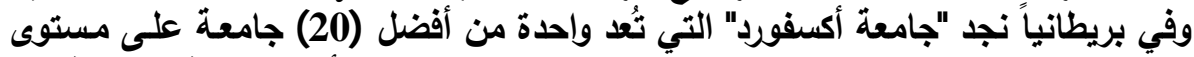

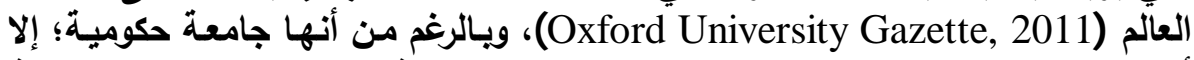

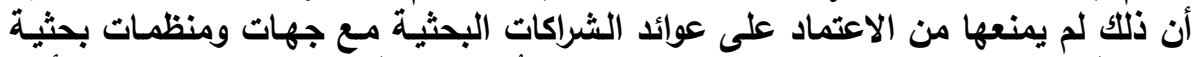

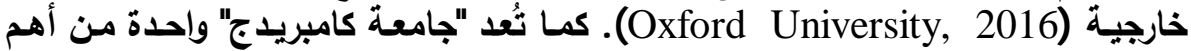

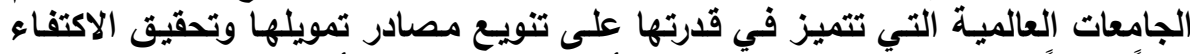

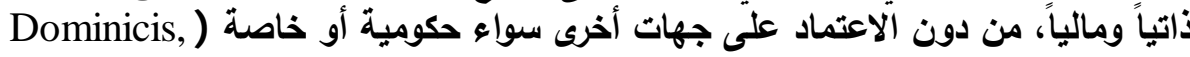


مجلة كلية التربية، جامعة الأزهر ، العدد: (183، الجزء الثاني) يوليو لسنة 2019م

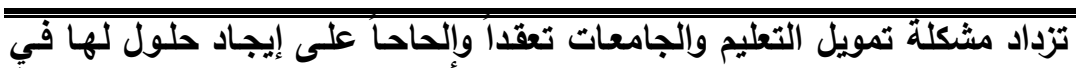

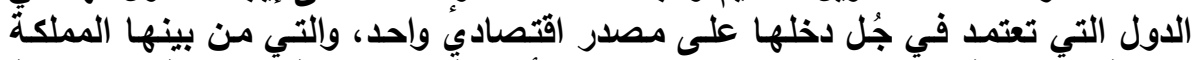

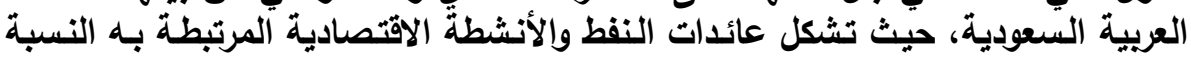

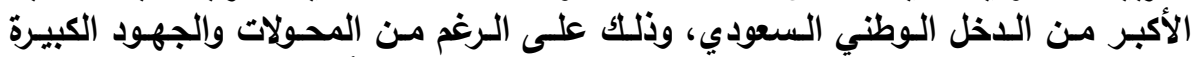

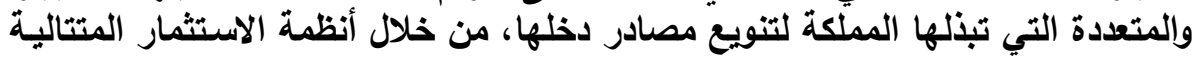

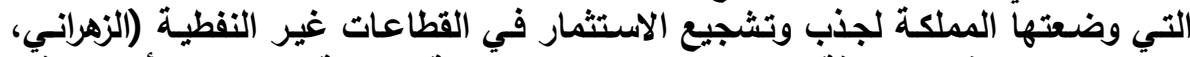

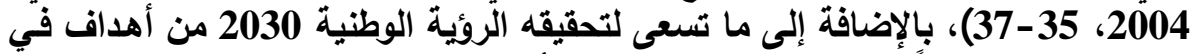

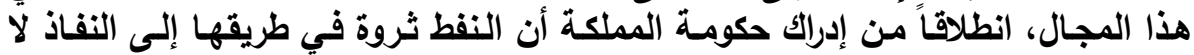

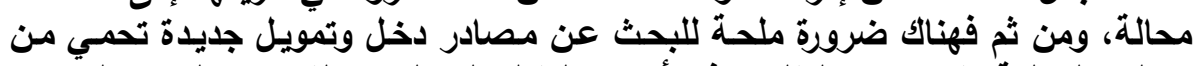

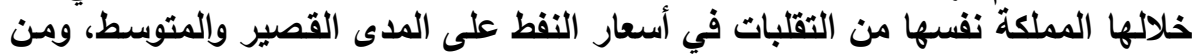
نفاذ النفط على المدى الطويل.

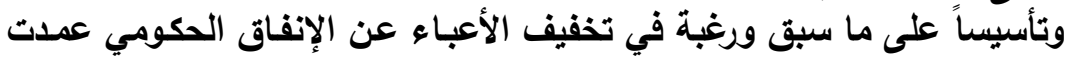

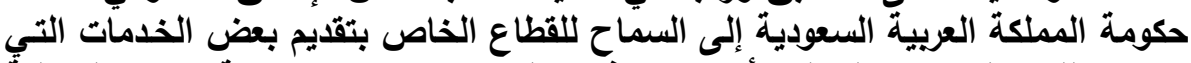

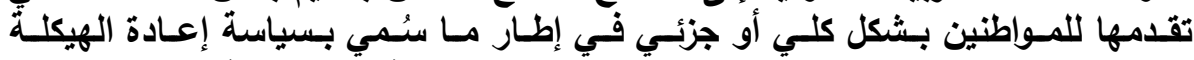

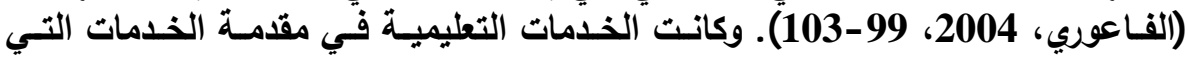

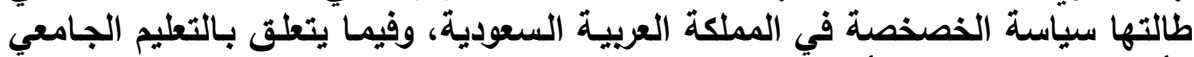

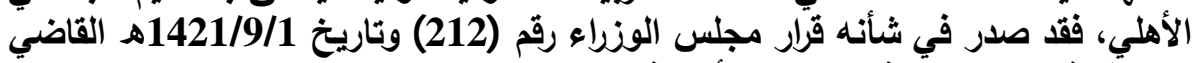

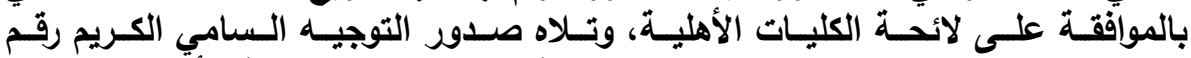

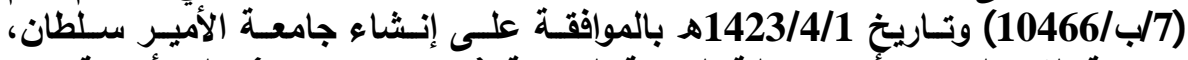

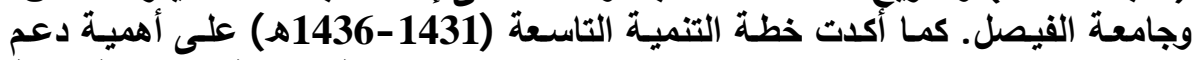

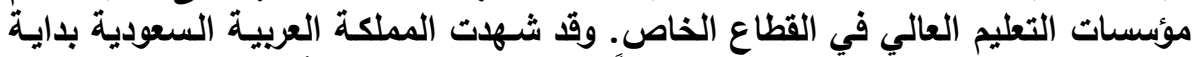

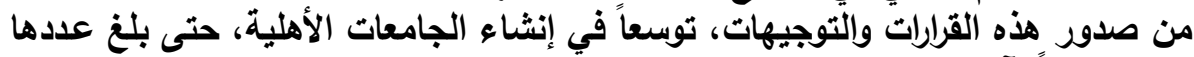

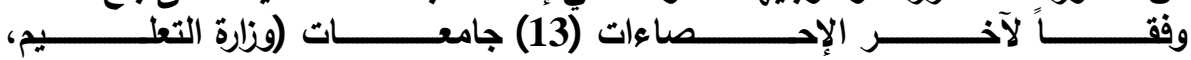

.(https://departments.moe.gov.sa

ومن الجدير بالذكر أن الجامعات الأهليـة السعودية ليست استثناء ممـا تعانيه

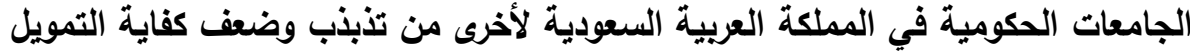

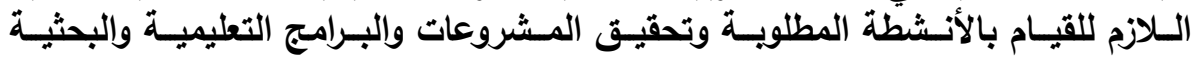

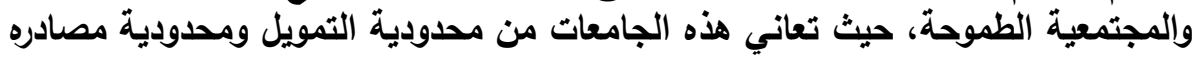

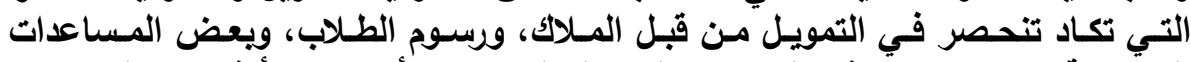

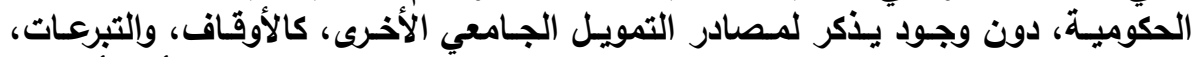

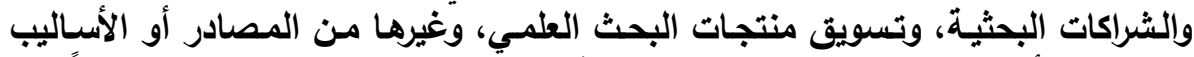

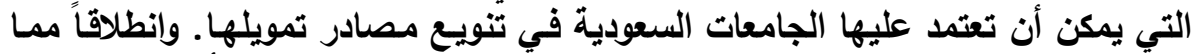

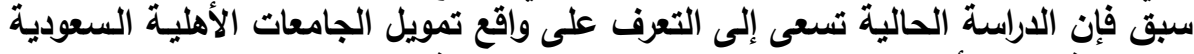

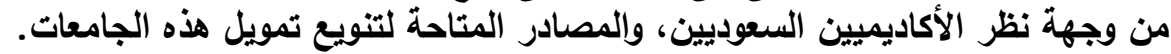


مشكلة الاراسة:

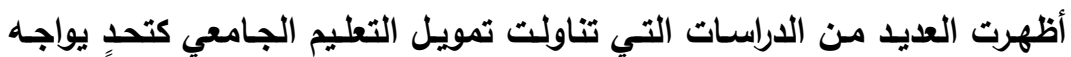

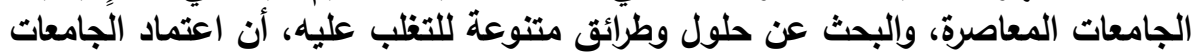

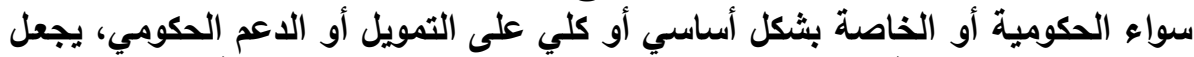

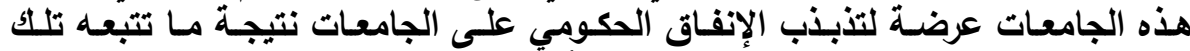

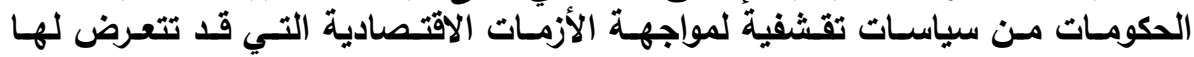

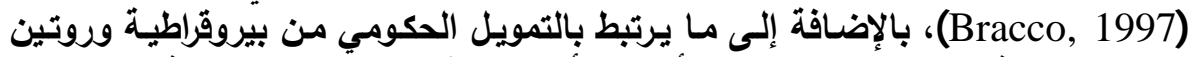

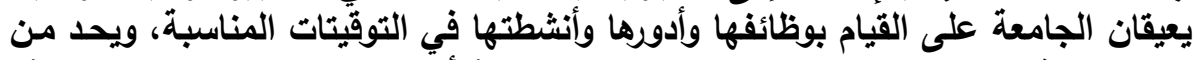

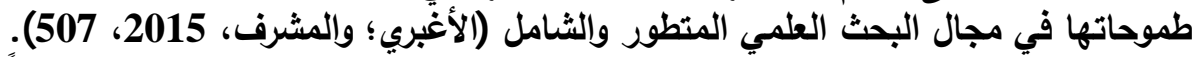

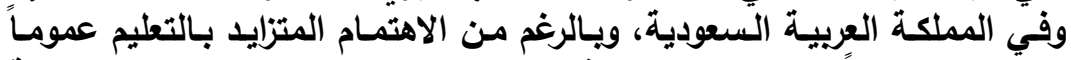

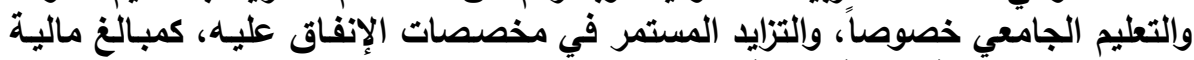

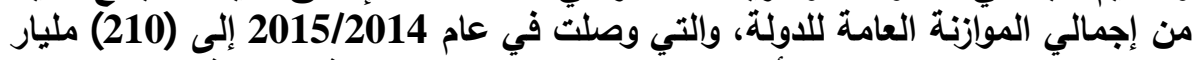

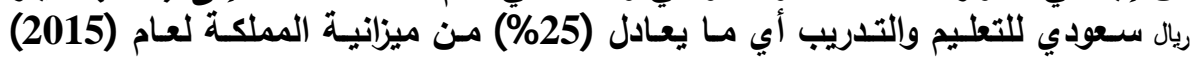

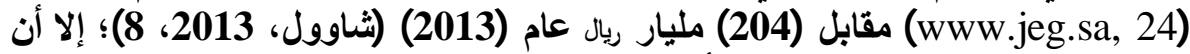

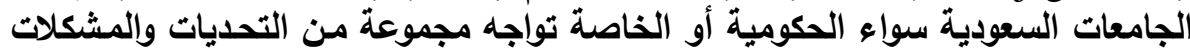

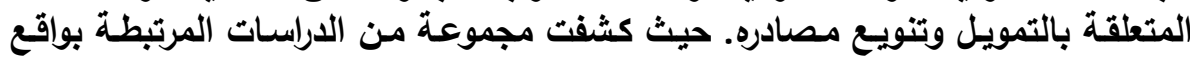

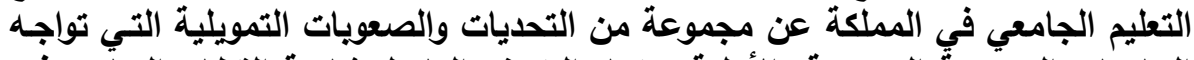

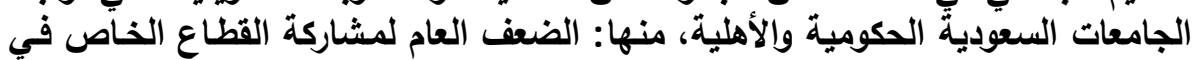

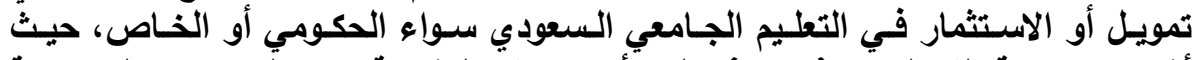

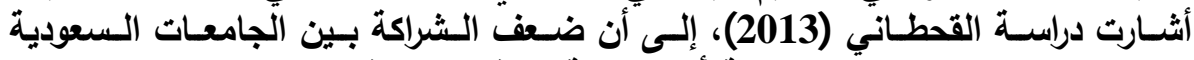

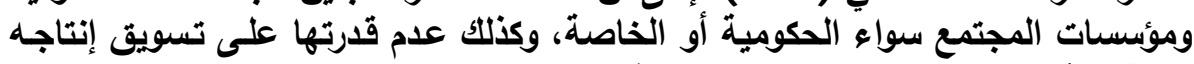

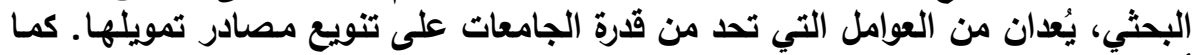

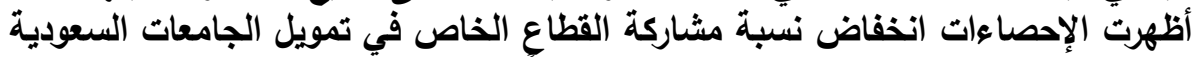

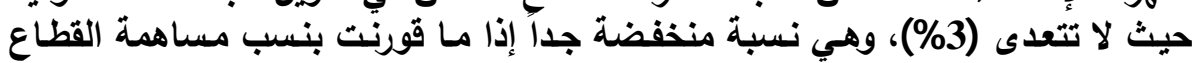

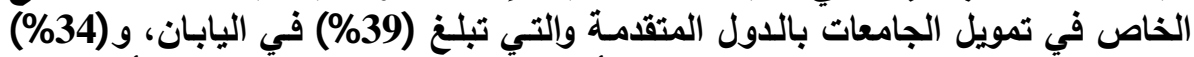

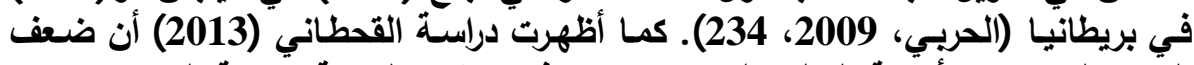

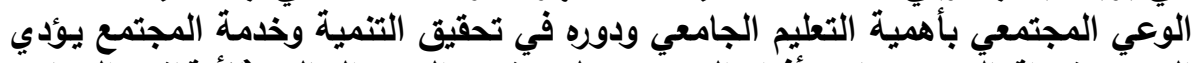

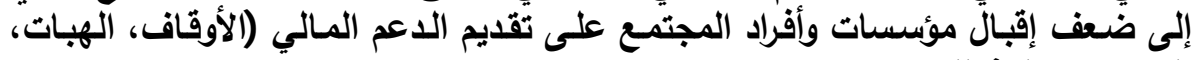

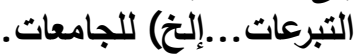

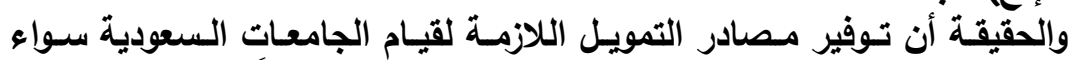

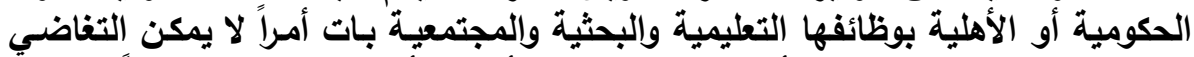

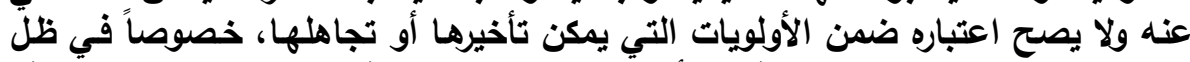

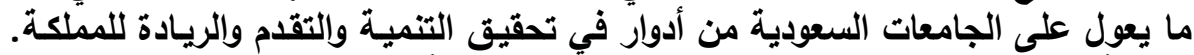

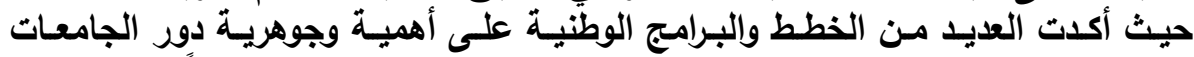

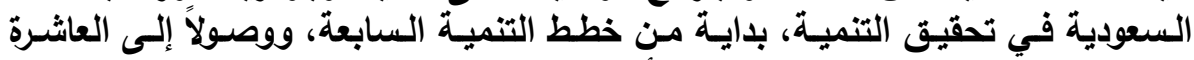

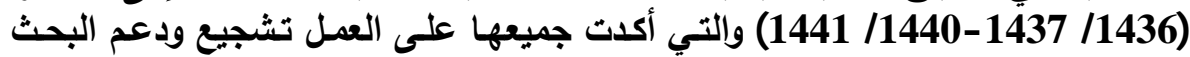

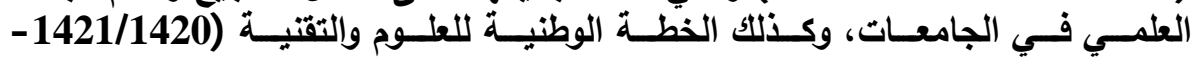


مجلة كلية التربية، جامعة الأزهر ، العدد: (183، الجزء الثاني) يوليو لسنة 2019م

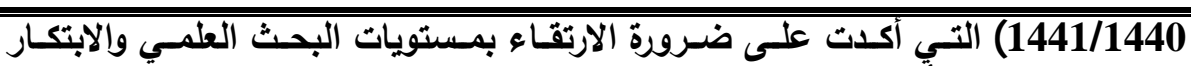

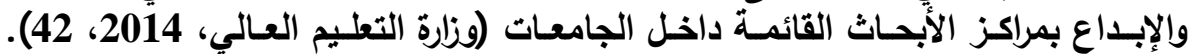

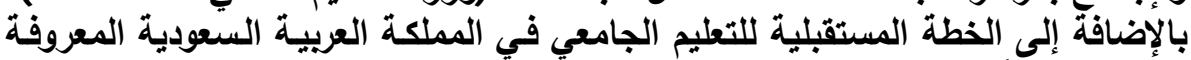

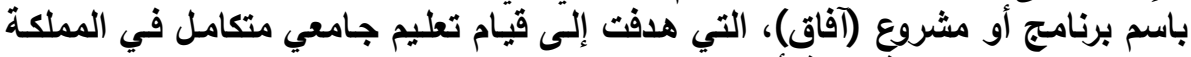

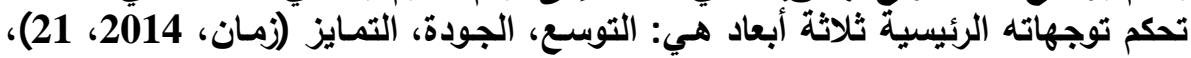

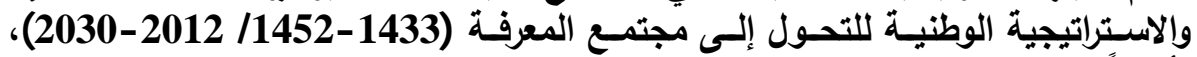

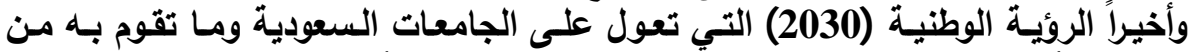

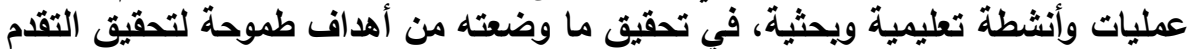

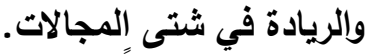

وانطلاثقاً مما سبق تسعى الداراسة الحالية إلى البحث عن أساليب وطرائق جديدة

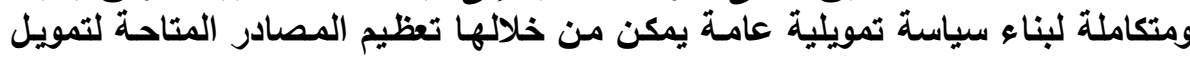

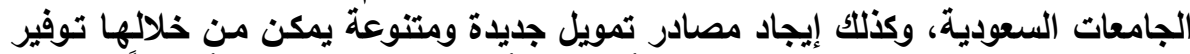

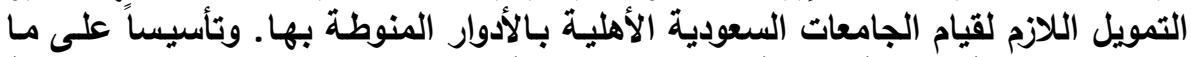

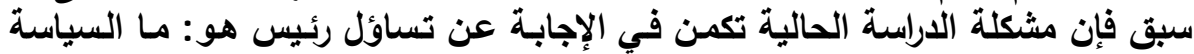
التمويلية المقترحة للجامعات الأهلية بالمملكة العربية السعودية العابة ؟

أسئلة الاراسة:

تسعى الدراسة الحالية للإجابـة على تساؤل رئيس وهو : مـا السياسة التمويلية

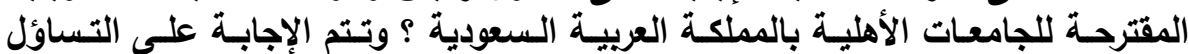

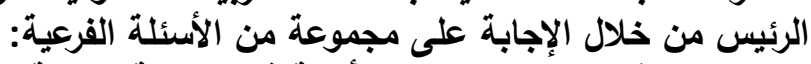

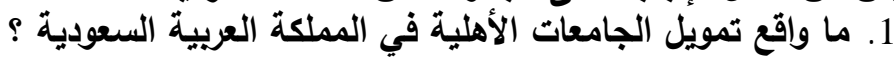

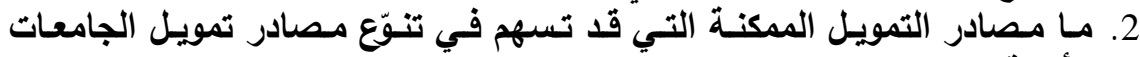

الأهلية؟

3. ما معوقات تمويل الجامعات الأهلية في المملكة العربية السعودية ؟

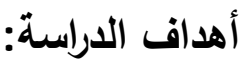

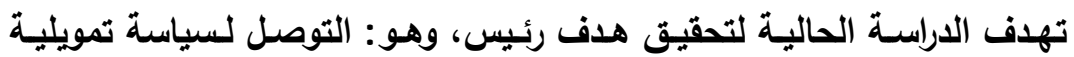

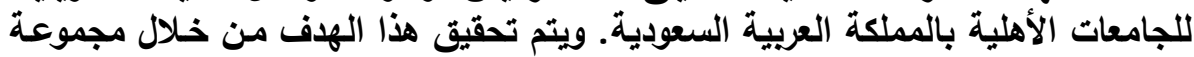

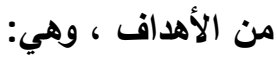

1. التعرف على واقع تمويل الجامعات الأهلية في المملكة العربية السعودية.

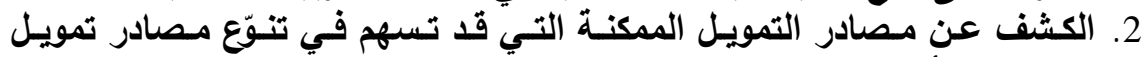

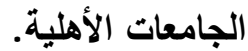

3. تحديد معوقات تمويل الجامعات الأهلية في المملكة العربية السعودية.

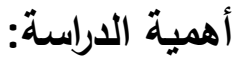

- إلقاء الضوء على مصادر تمويل الجامعات الأهلية في المملكة العربيـة السعودية،

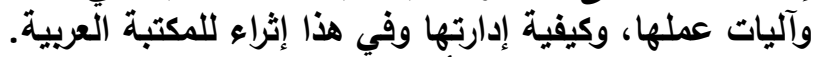

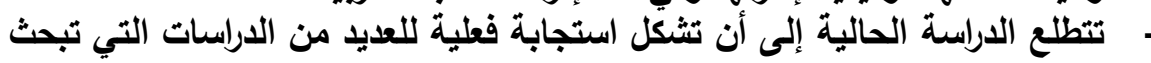


عن إيجاد سبل تمويل مقترحة (غير تقليدية) لتمويل التعليم الجامعي الأهلي، من

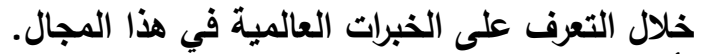

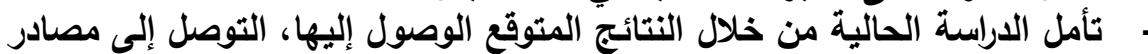

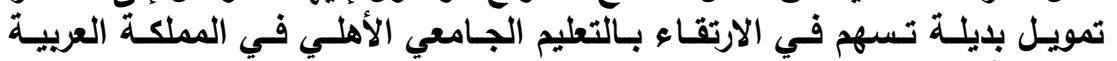
السعودية. - التوصل لنتائج تساعد القائمين على عملية التمويل في الجامعات السعودية بوجهـ

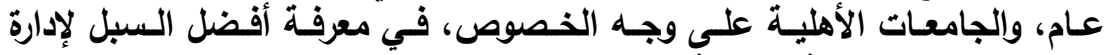
مصادر التمويل الحالية والبديلة.

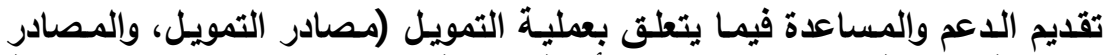

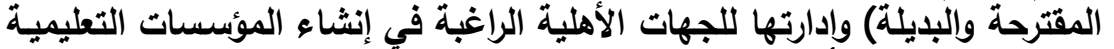
الأهلية سواء أكانت ألجامعات أو المعاهد العليا والكليات الأهلية. حدود الدراسة:

1. الحدود الموضوعية: يقتصر موضوع الدراسة الحالي على وضع (بناء سياسـة تمويلية

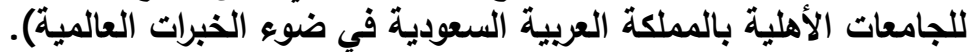

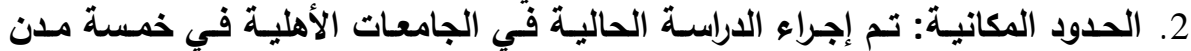

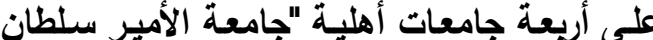

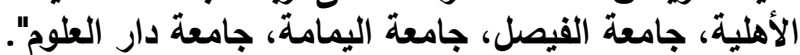

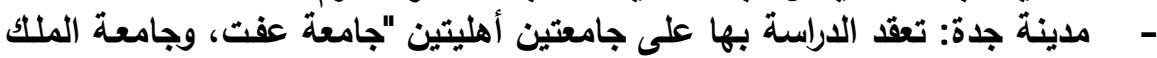

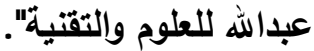

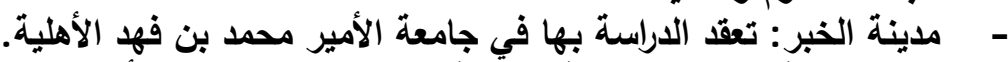

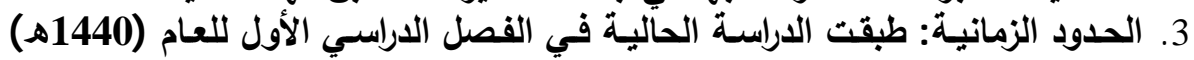
الموافق (2019/2018م).

4. الحدود البشرية: ستشمل الحدود البشرية في الدراسة الحالية كافة العمداء ومديري

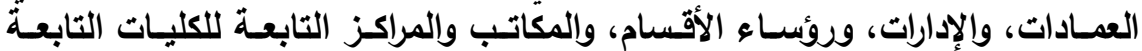

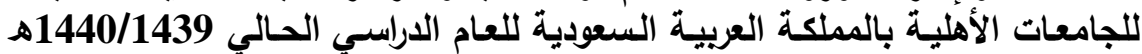

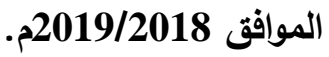




1 مصطلحات الاراسة:

السياسة: الطريقة التي يعيش بها الناس معاً ويحكون أنفسهم للمصلحة

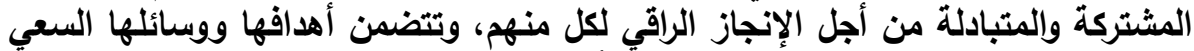

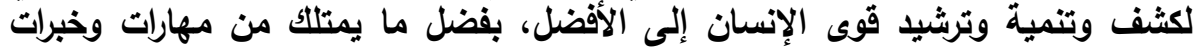

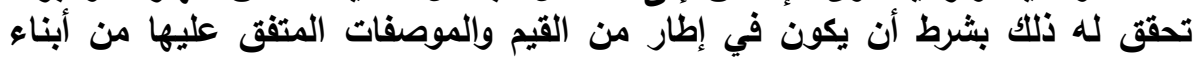

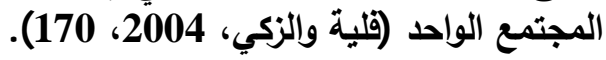

التمويل: مجموعة الموارد المالية المرصودة للمؤسسات التعليمية لتحقيق أهداف

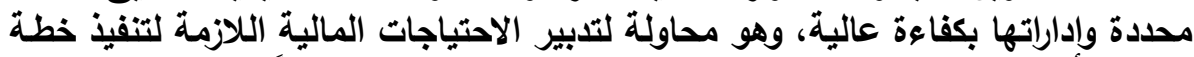

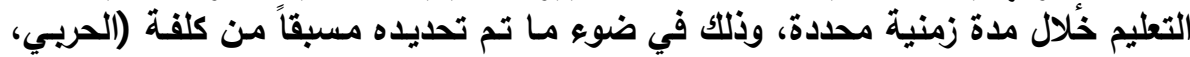

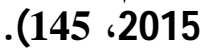

أما بناء السياسة التمويلية فتُعرّف إجرائياً بأنها: حزمـة من الإجراءات والتتدابير

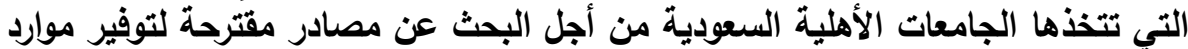

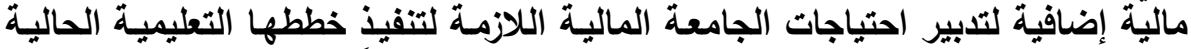
والمستقبلية وذلك في ضوء الخطة المالية التي وضعتها مسبقاً. 2.تمويل التعليم الجامعي الأهلي:

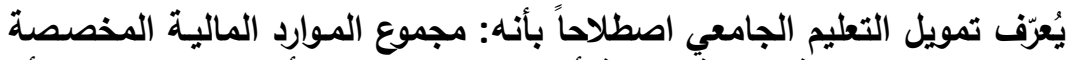

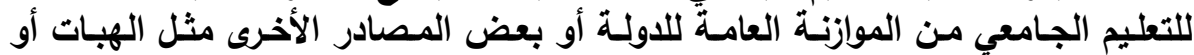

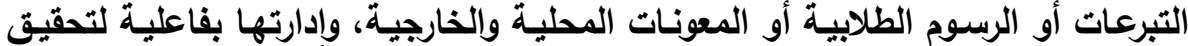
أهداف التعليم الجامعي خلال فترة زمنية محددة (المالكي، 2013، 116).

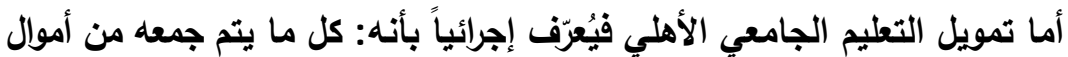

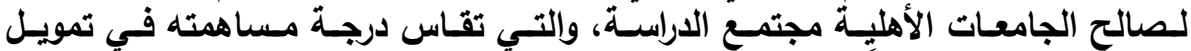

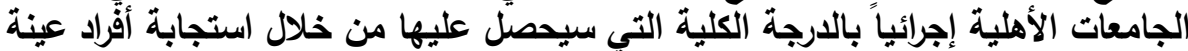

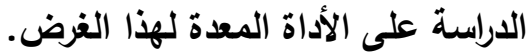

3. الجامعات الأهلية:

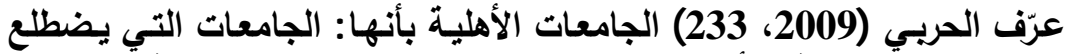

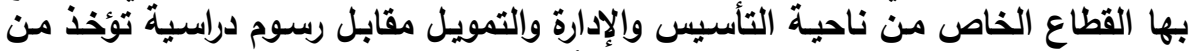

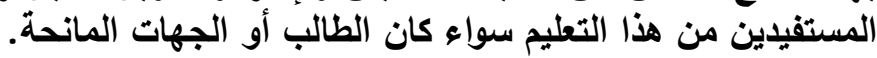

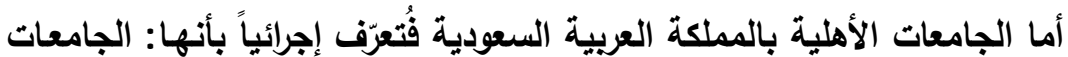

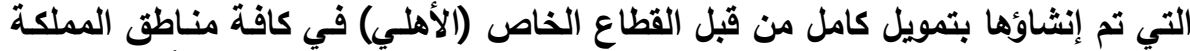

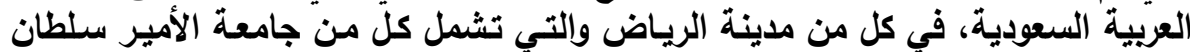

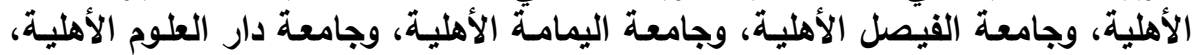
والجامعة العربية المفتوحة الأهلية، ومدينة جدة والتي التئة تثمل كل من جامعة وجلة عفت الأهلية، 


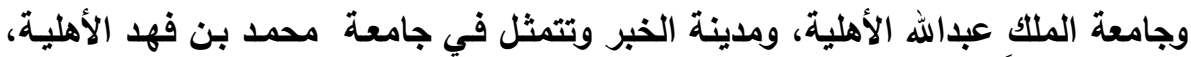

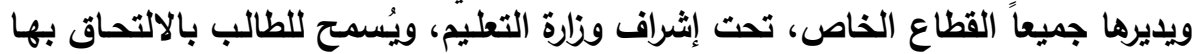

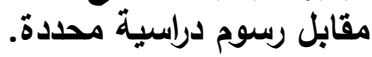

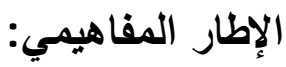
أولاً: مفهوم التعليم العالي الأهلي:

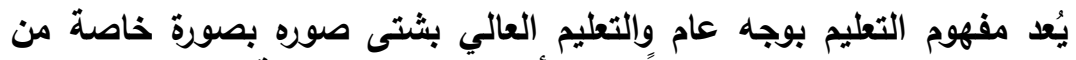

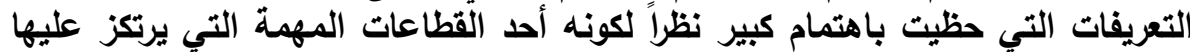

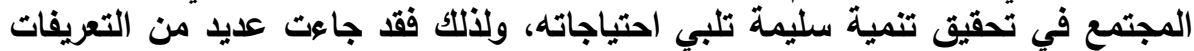

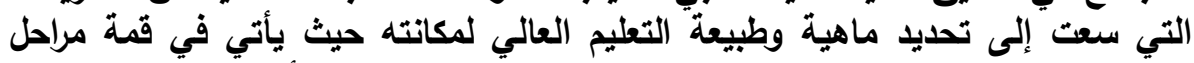
التعليم والتي ينتظر المجتمع بمؤسساته ومنظماته مخرجاته لتحقيق أهدافهُ وتُطلعاته.

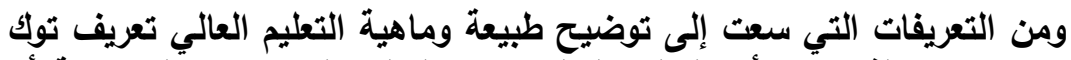

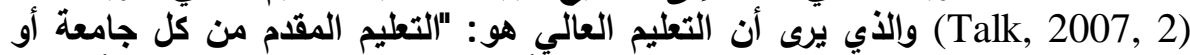

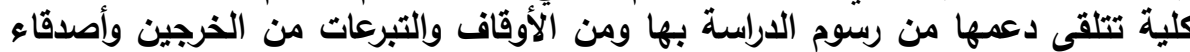

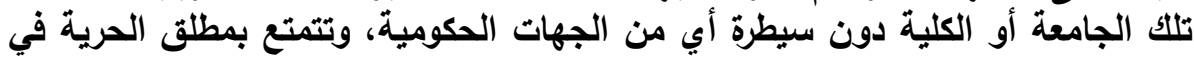

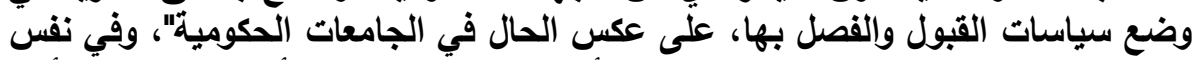

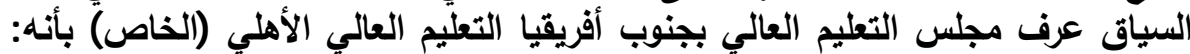

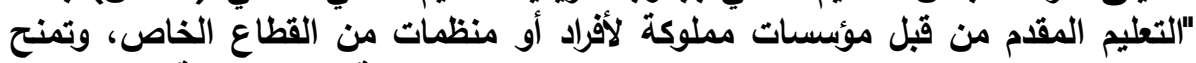

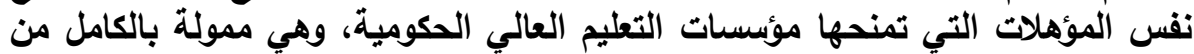
القطاع الخاص، وتثرف عليها الدولة" (Council on Higher Education, 2018).

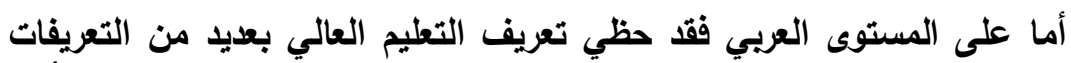

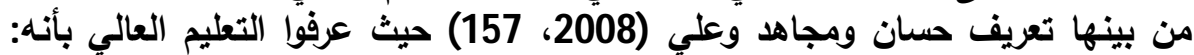

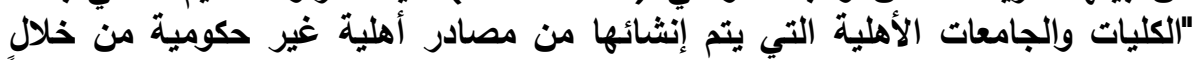

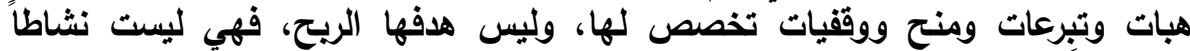

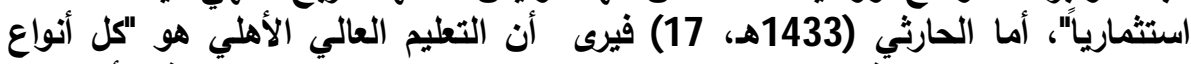

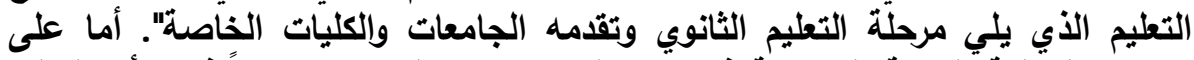

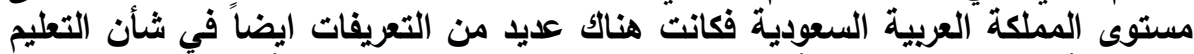

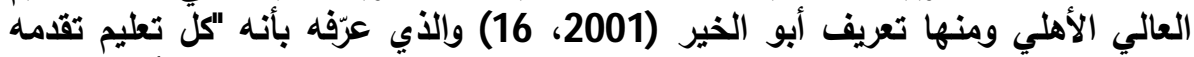

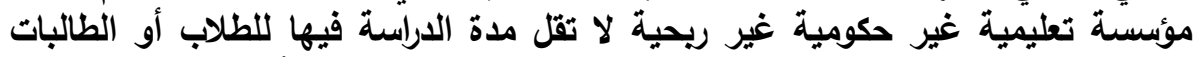

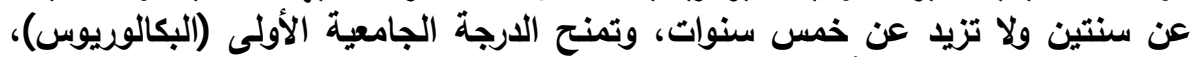

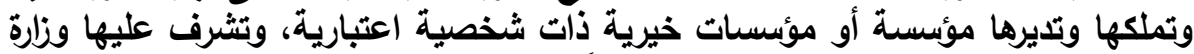

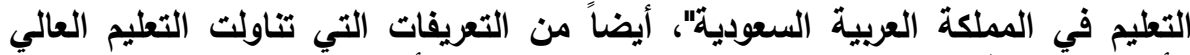

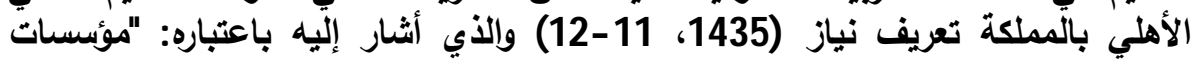

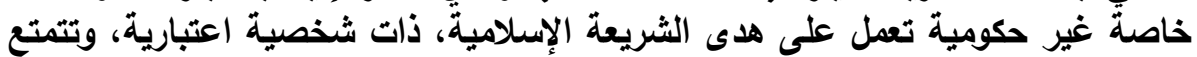

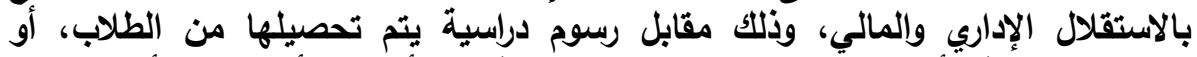

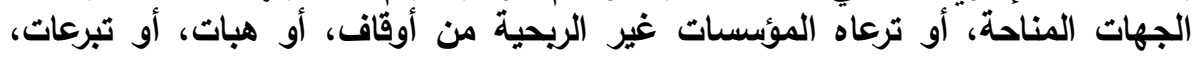


مجلة كلية التربية، جامعة الأزهر ، العدد: (183، الجزع الثاني) يوليو لسنة 2019م

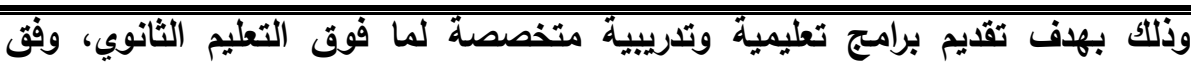

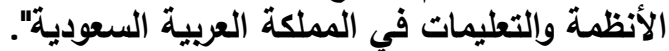

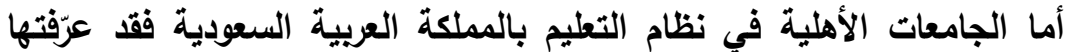

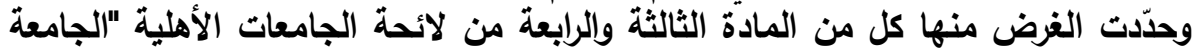

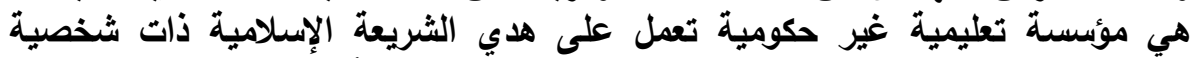

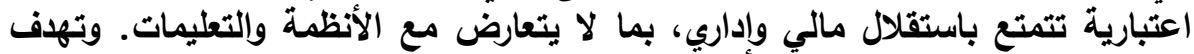

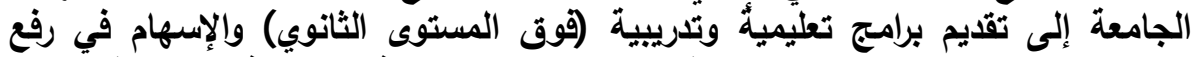

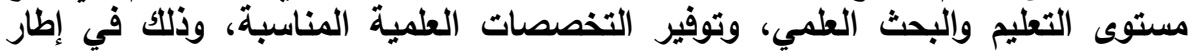

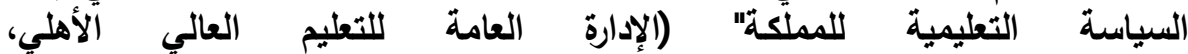
. ، (https://departments.moe.gov.sa 2018

نشأة التعليم العالي الأهلي في المملكة العربية السعودية:

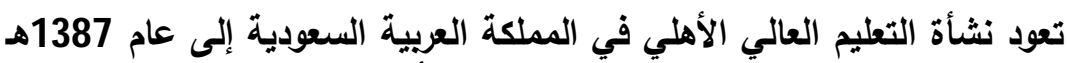

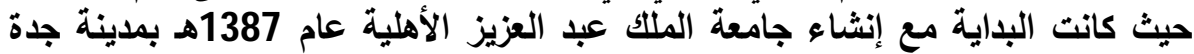

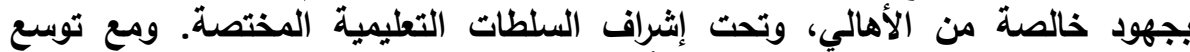

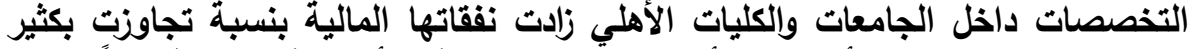

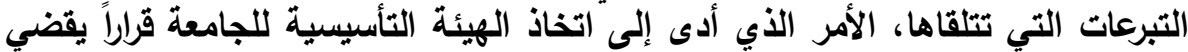

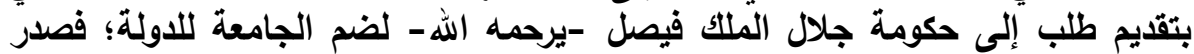

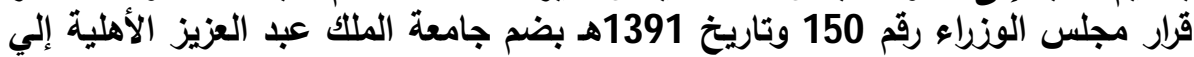

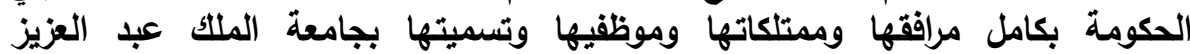

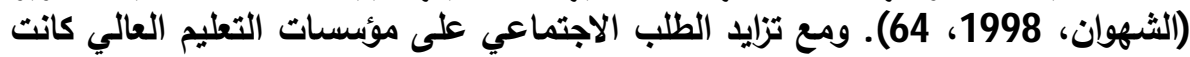

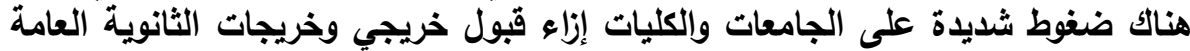

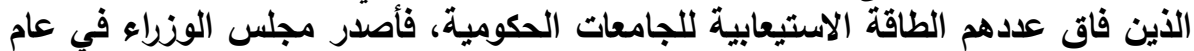

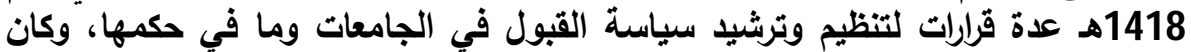

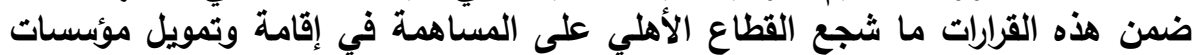

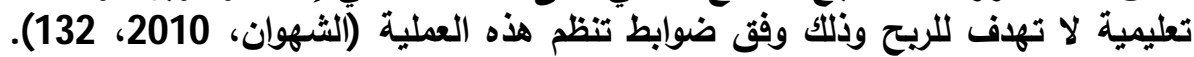

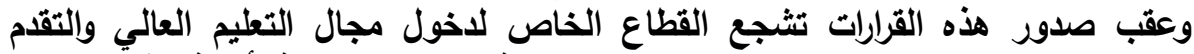

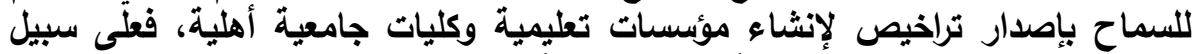

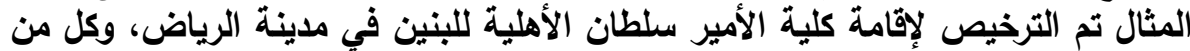

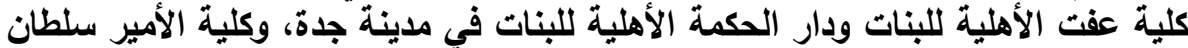

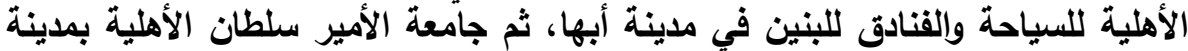

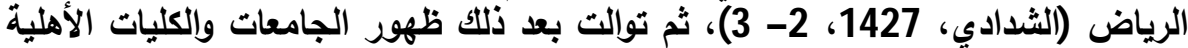
في عديد من مناطق السعودية والتي راعت البُعد الجغرافي والسكاني. 
مصادر تمويل التعليم الجامعي في المملكة العربية السعودية:

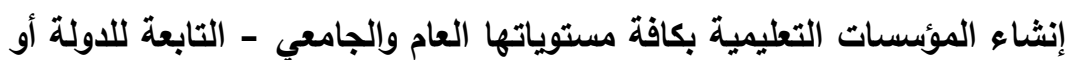

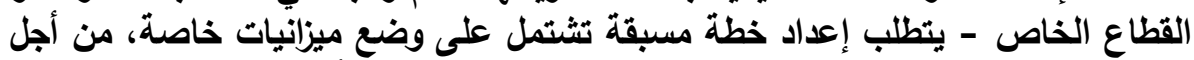

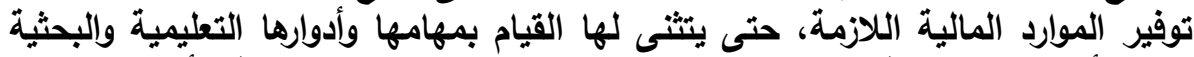

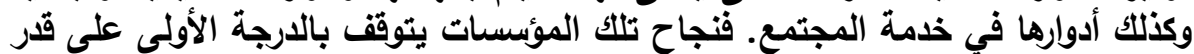

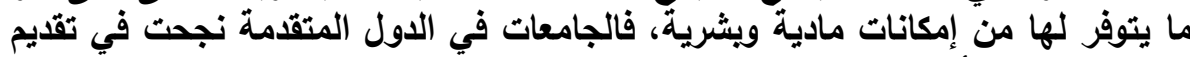

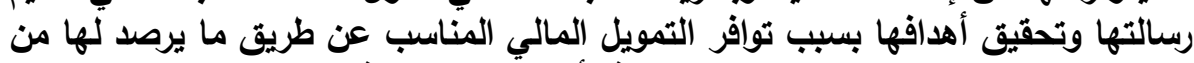

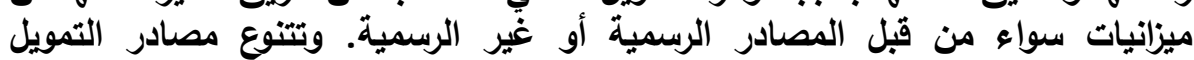

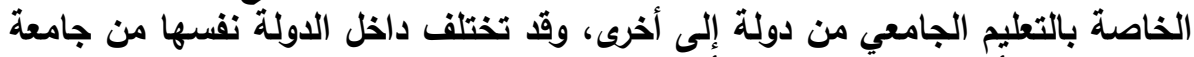

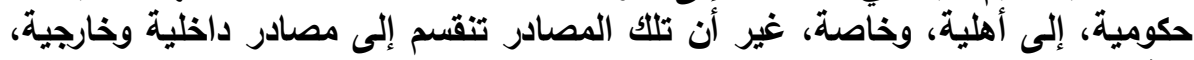

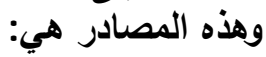

1. المصادر الداخلية: ويقصد بهذه المصادر الموارد المالية التي يمكن توفيرها للجامعة من داخلها ومن بينها:

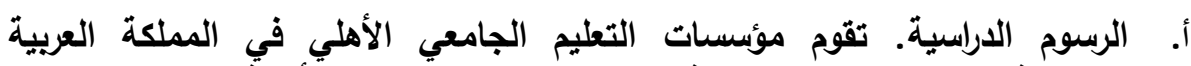

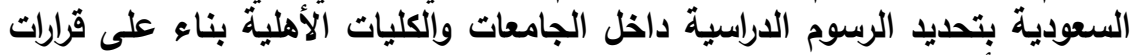

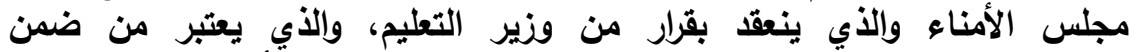

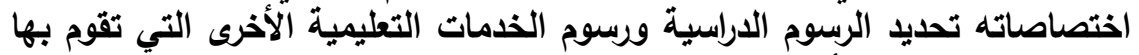

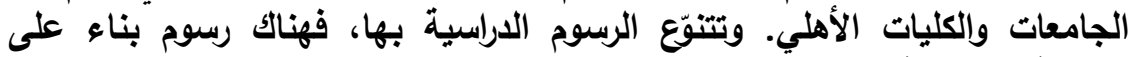

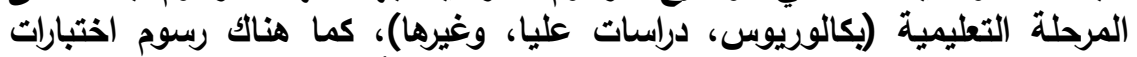

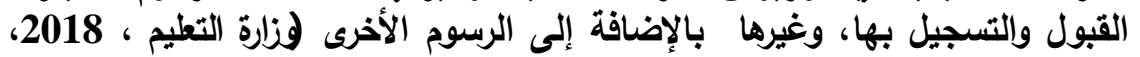
(www.moe.gov.sa ب. الجامعات المنتجة: من بين الجامعات السعودية التي انتهجت نموذج الجامعة المنتجة

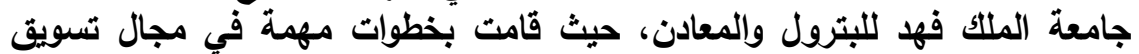

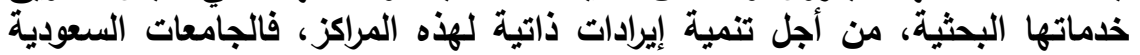

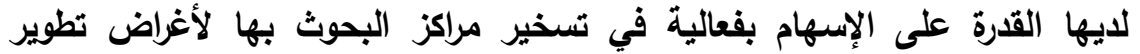

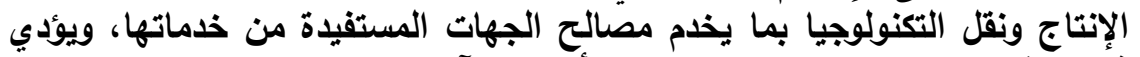

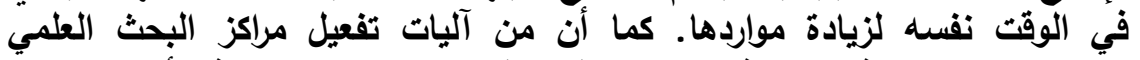

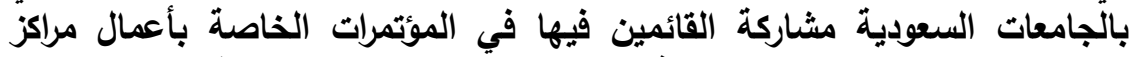

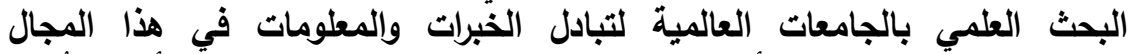

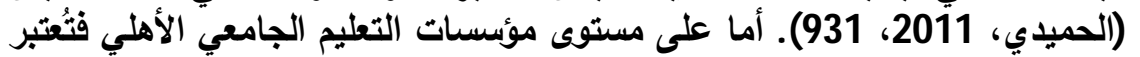

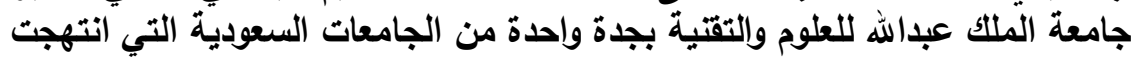

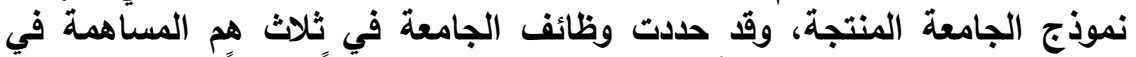

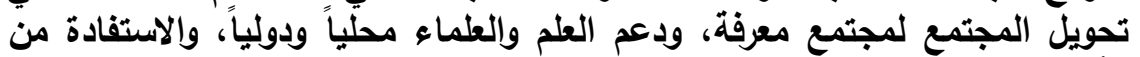
الأبحاث في التنمية الاقتصادية (عماره، 2012، 362). 
مجلة كلية التربية، جامعة الأزهر، العدد: (183، الجزء الثاني) يوليو لسنة 2019م

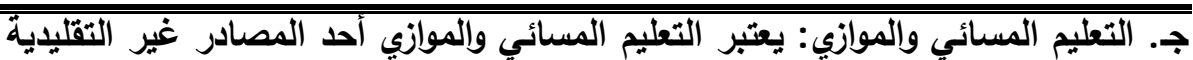

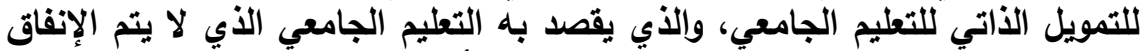

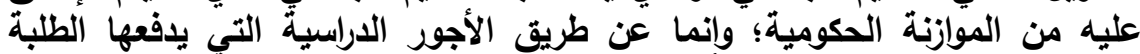

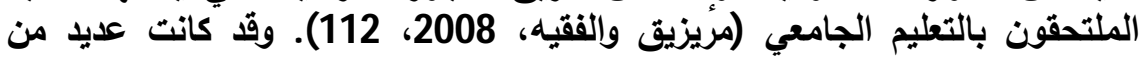

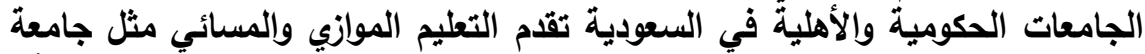

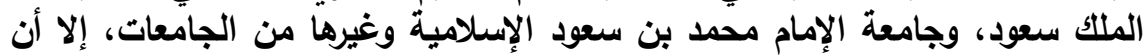

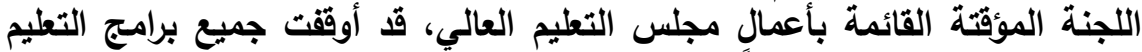

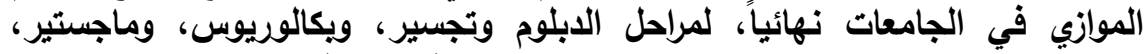

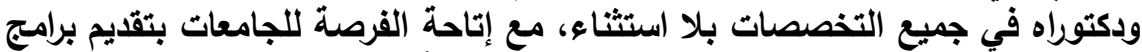

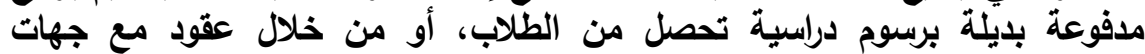

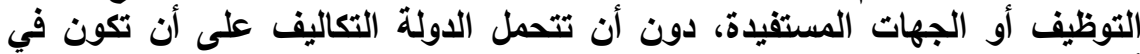
أضيق الحدود، وفي التخصصات المطلوية لسوق التئية العمل الوزارة التطليم، 2018، . (www.moe.gov.sa

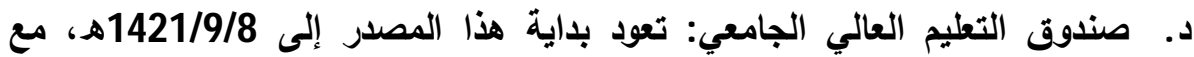

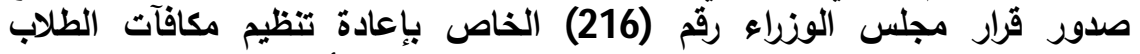

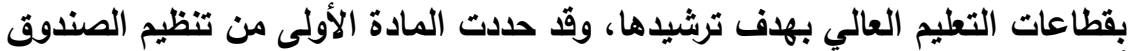

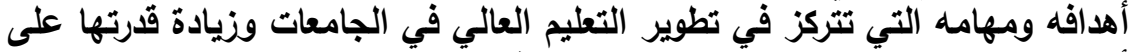

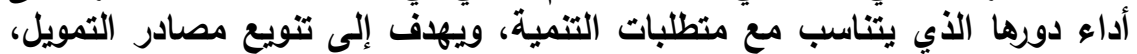

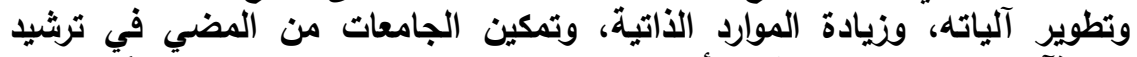

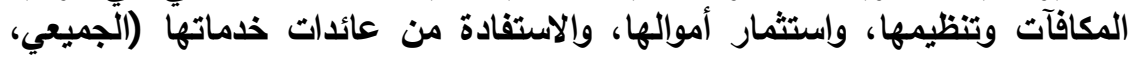

.28 25 2015 25

2. المصادر الخارجية: وهي مصادر تعتمد عليها عديد من الجامعات في توفير

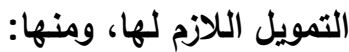

أ. التمويل الحكومي: ويقصد بالتمويل الدكومي "حجم الأموال التي تستقطع من الناتج

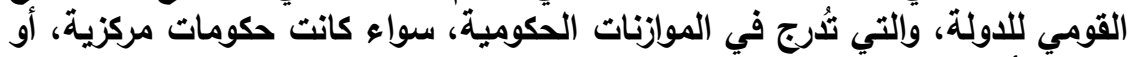

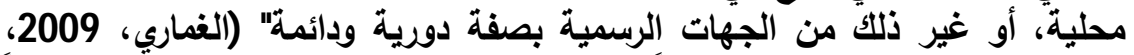

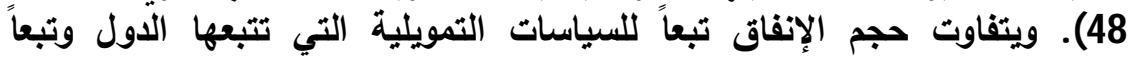

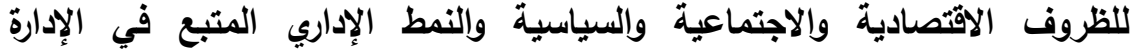

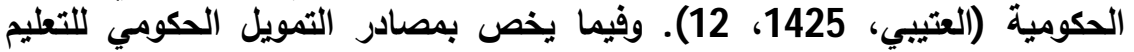
الجامعي في المملكة العربية السعودية فقد نصتية المادة (230) من سياسة التعلية التعليم

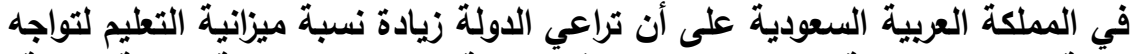

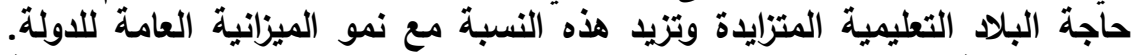

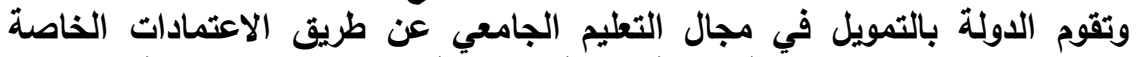

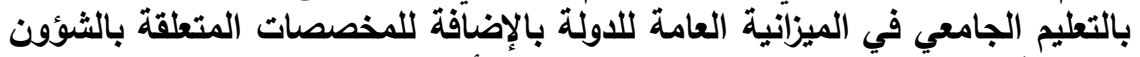

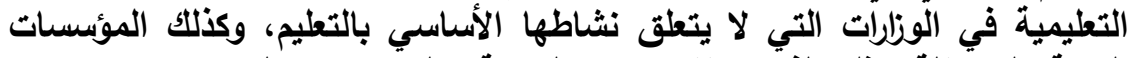
العامة المستقلة مثل الذي تنفقه وزارة الصحة على معاهد التمريض ومساعلي التياتي 


$$
\text { المختبرات (سليم، 1425، } 24 \text {-25). }
$$

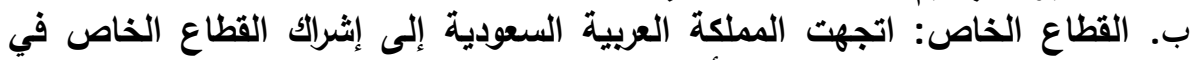

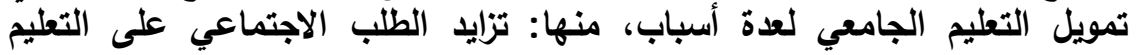

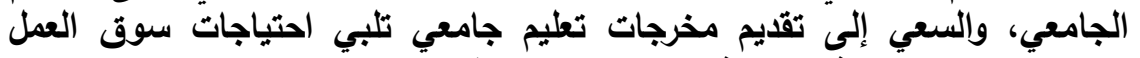

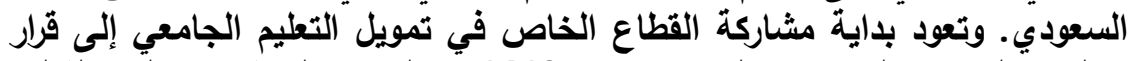

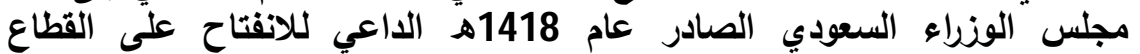

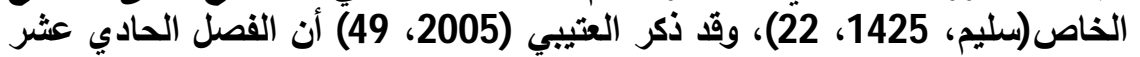

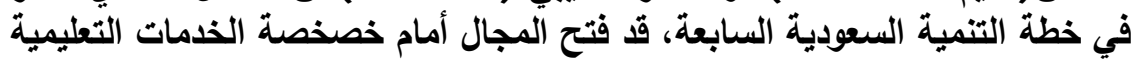

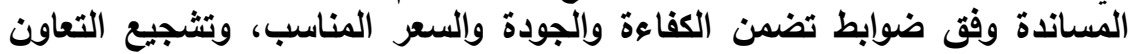

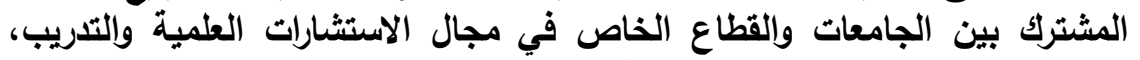

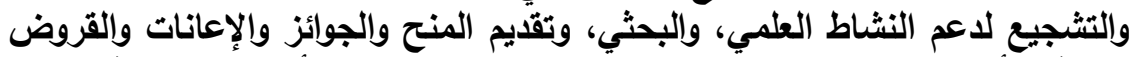

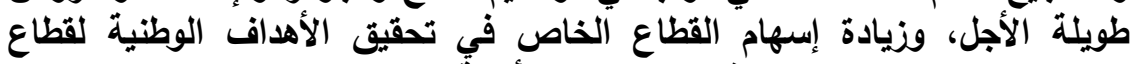

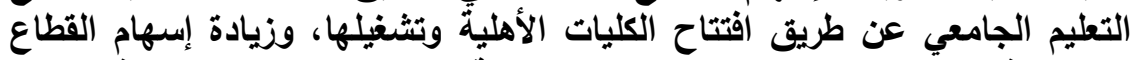

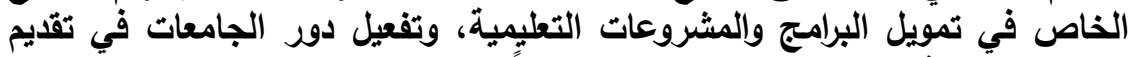

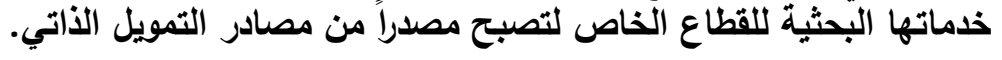

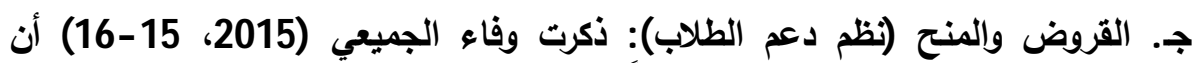

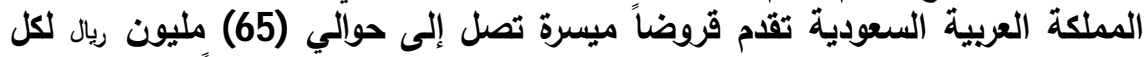

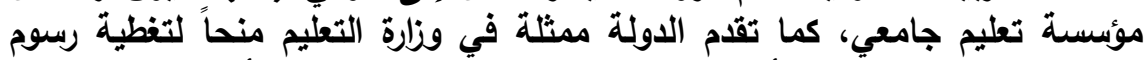

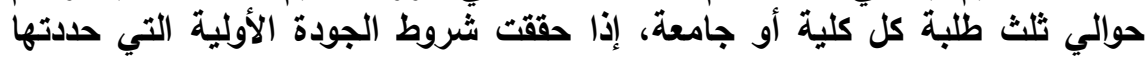
الوزارة.

د. التمويل الأهلي (الثعب): ويشمل هذا المصدر من التمويل في مؤسسات التعليم

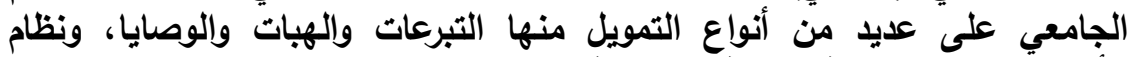

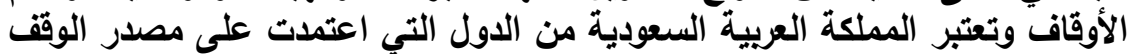

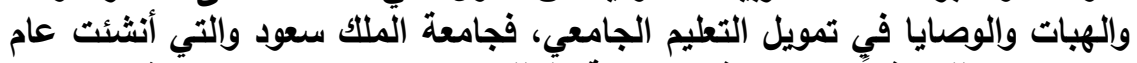

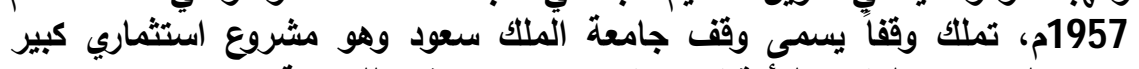

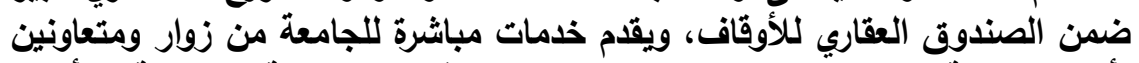

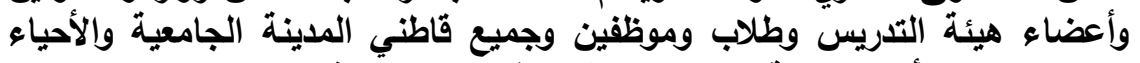

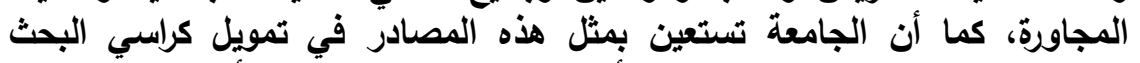

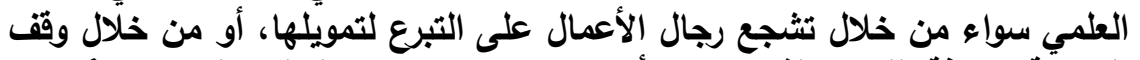

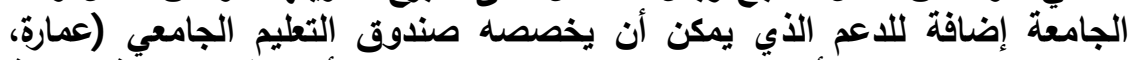

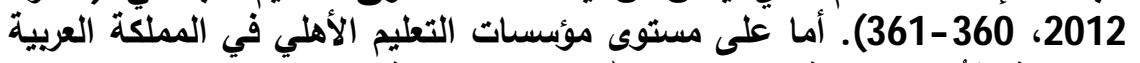

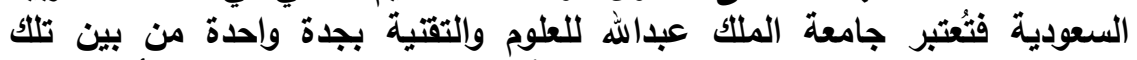

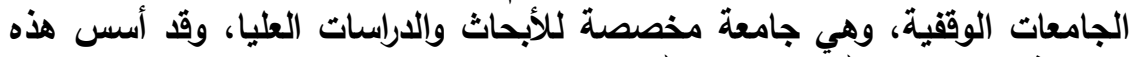

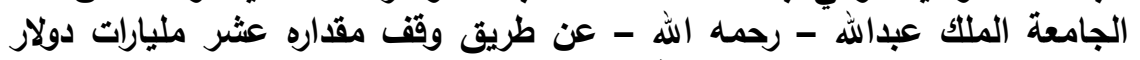

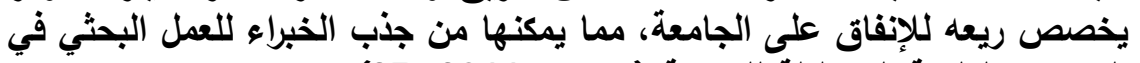

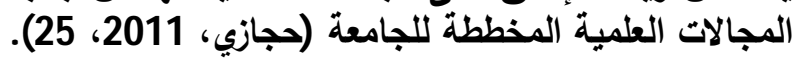


مجلة كلية التربية، جامعة الأزهر ، العدد: (183، الجزء الثاني) يوليو لسنة 2019م

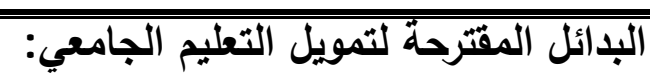

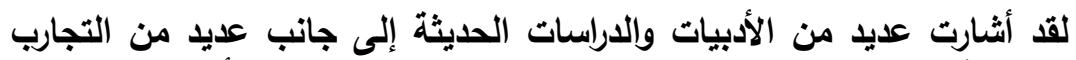

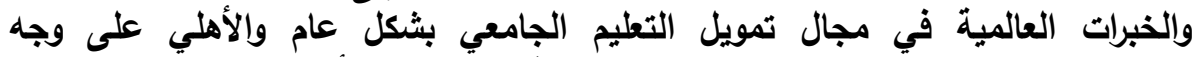

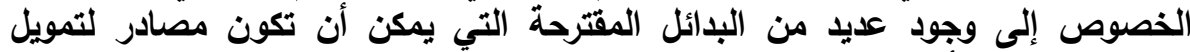
التعليم الجامعي الأهلي ومن بين هذه مذال البدائل ما يلي:

1. أساليب التمويل البليلة لتمويل التعليم الجامعي وسياساتها ومتطلباتها:

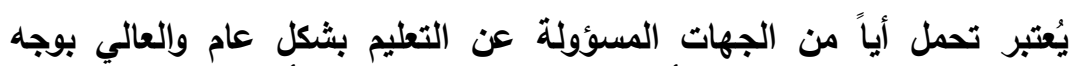

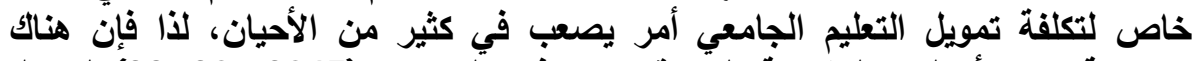
مجموعة من الأساليب المقترحة التي قدمتها وفاء ألجميعي (2015، 20 -23) لتمويل

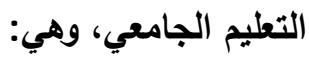

- الأسلوب الأول: استمرار الدولة في تمويل التعليم الجامعي بما يتطلبه من تكلئة

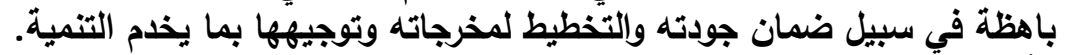

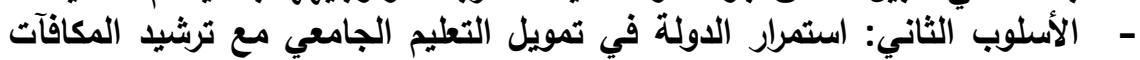

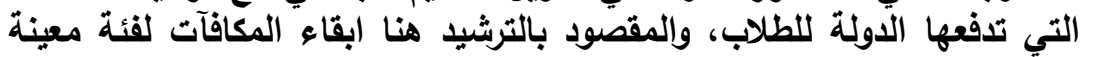

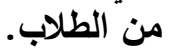
- الأسلوب الثالث: استمرار ترشيد المكافآت وتحمل الطلبة نسبة معينة من تكاليف

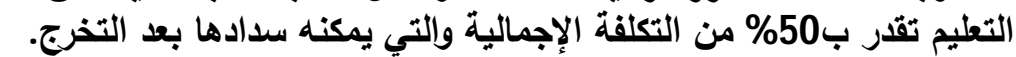

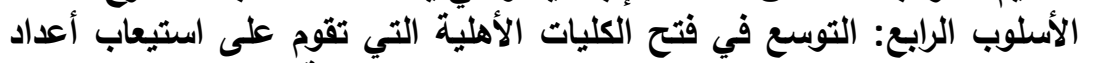

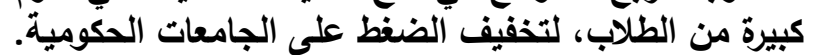

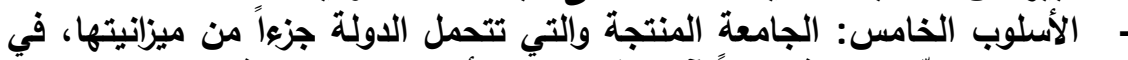

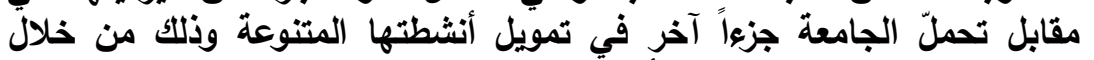

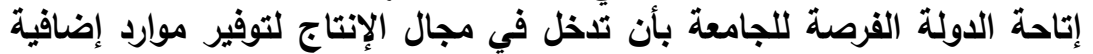

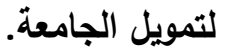

2. مصادر التمويل الذاتي كبدائل لتمويل مؤسسات التعليم الجامعي:

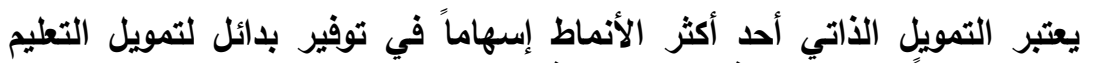

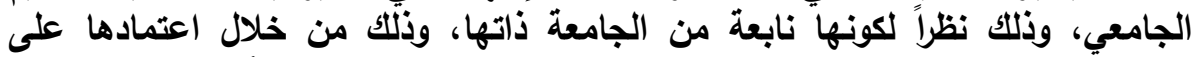

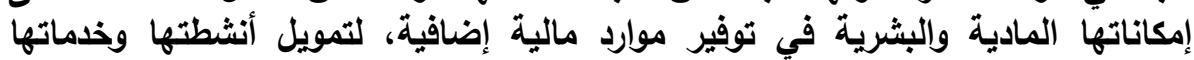

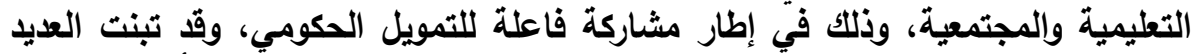

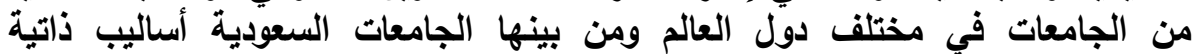
كمصادر إضافية لتمويل الجامعات.

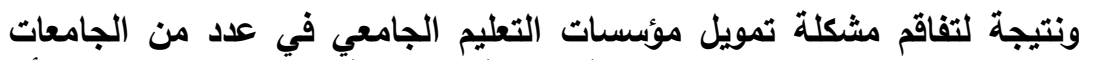

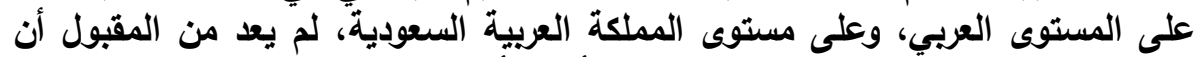

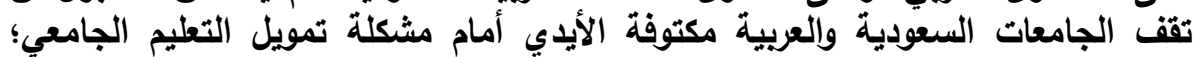

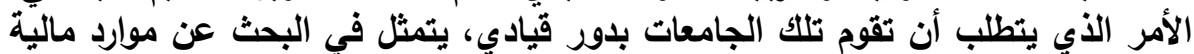

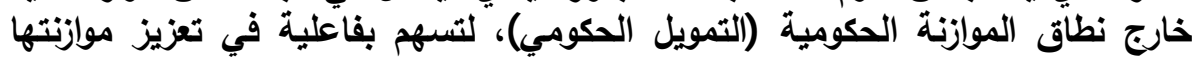


السنوية (الصغير، 2005، 179)، وقث عددّ كل من عبدريه (2013، 85 (90)، ومنال، ومنال

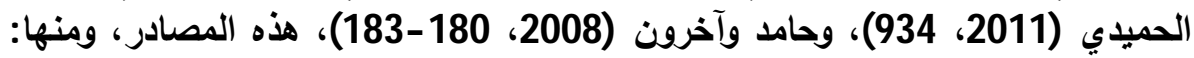

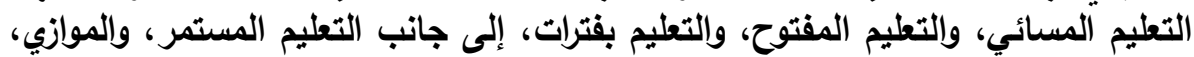
والتعاوني، والتعليم عن بُعد (الجامعة الافتراضية) وغيرها.

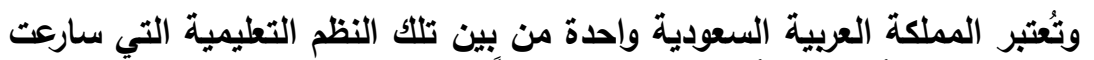

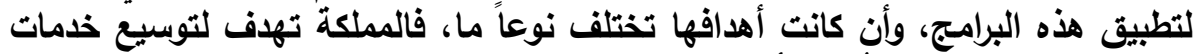

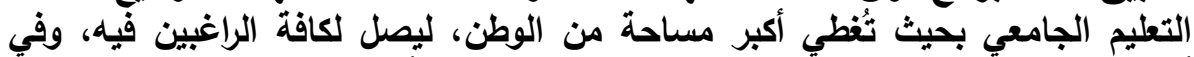

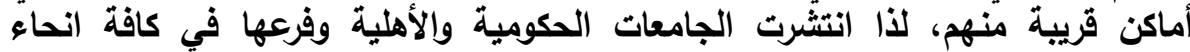

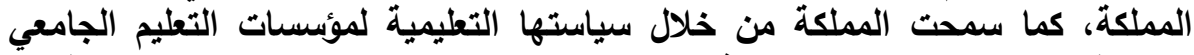

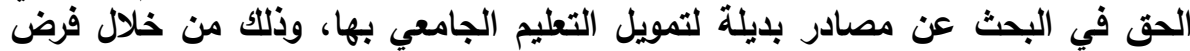

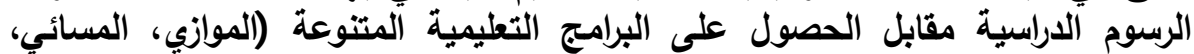

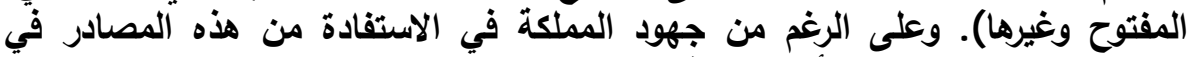

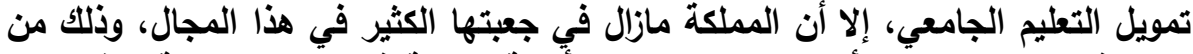

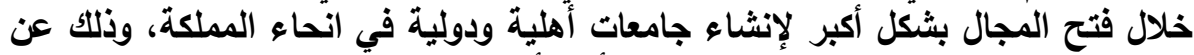

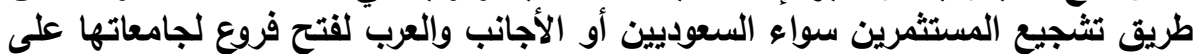

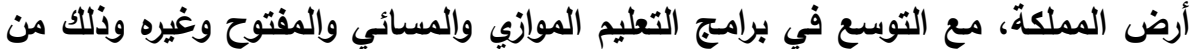
خلال دعم هذه البرامج بشكل واضعت في برائ.

3. ترشيد الإنفاق على التعليم الجامعي وتوفير بدائل لتمويل التعليم الجامعي:

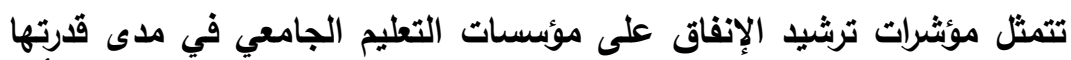

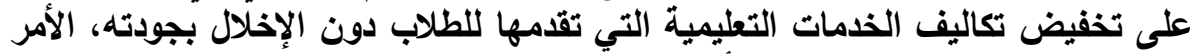

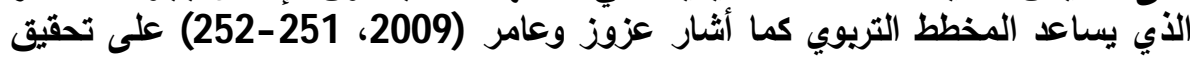
عديد من الأهداف ذات الصلة بمسألة تمويل التعليم العالي، ومن بينها:

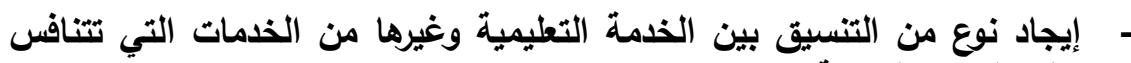
على الموارد المتاحة. - توزيع الموارد المتاحة بشكل عام ومنطقي بين الاحتياجات المتنوعة للتعليم الجامعي.

- التأكد من أن الأجهزة التعليمية تجيد استغلال الموارد المخصصة لها.

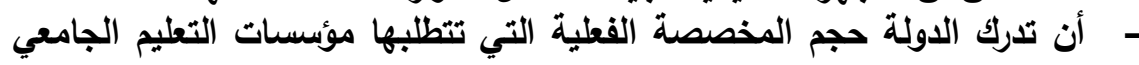

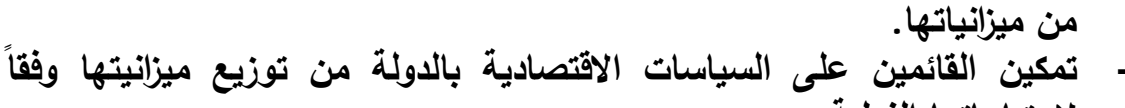
لاحتياجاتها الفعلية.

4. التوسع في التمويل الجامعي القائم على نظام الوقف والتبرعات: تُمثل الأوقاف أحد أدوات المجتمع التي يتم الاستعانة بها لتحسين وتطوير عمل 
مجلة كلية التربية، جامعة الأزهر، العدد: (183، الجزء الثاني) يوليو لسنة 2019م

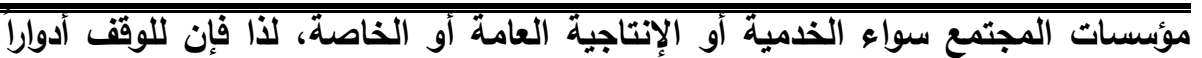

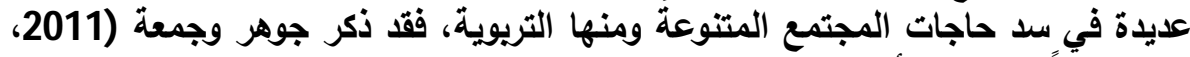

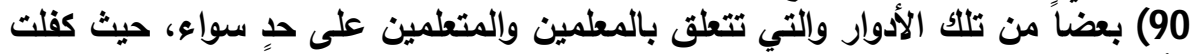

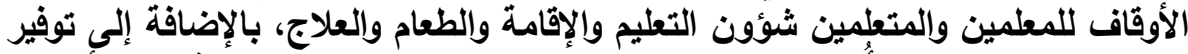

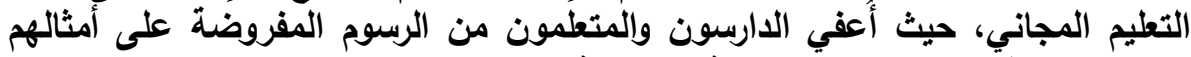
ممن يتلقون في المؤسسات التعليمية الحكومية.

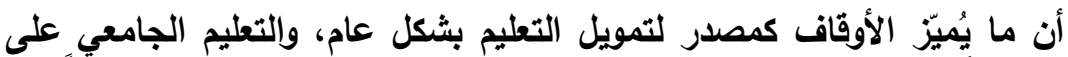

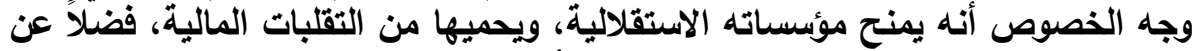

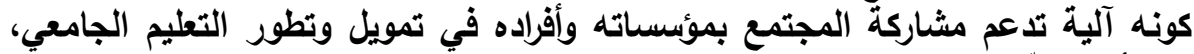

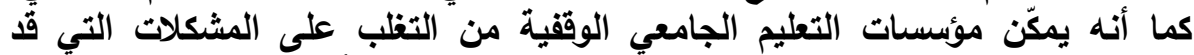

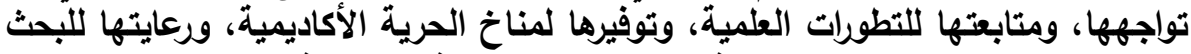

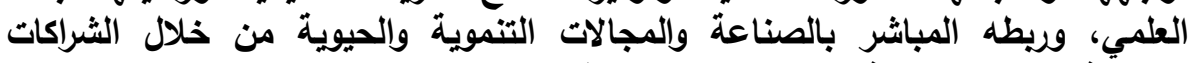

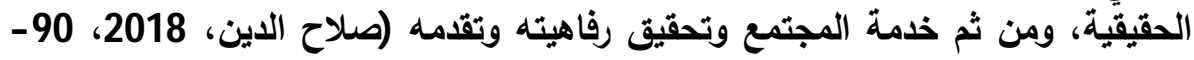

6. التوجه إلى القطاع الخاص لتمويل التعليم الجامعي:

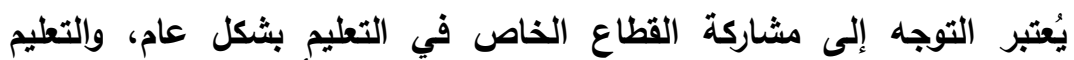

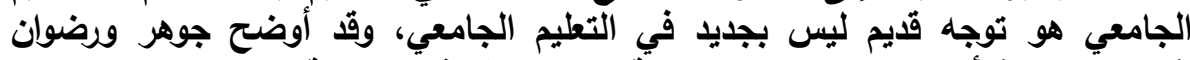

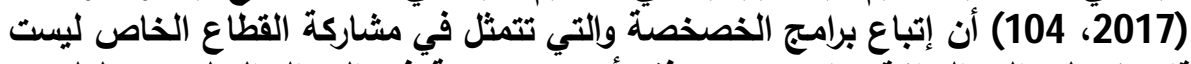

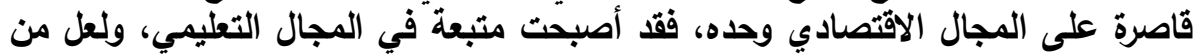

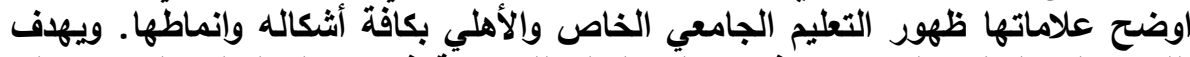

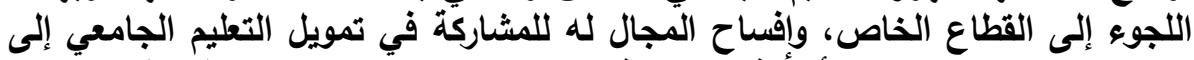

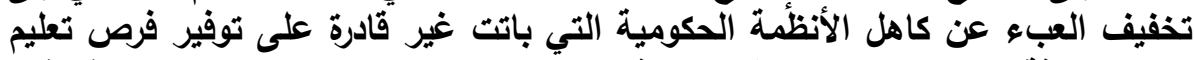

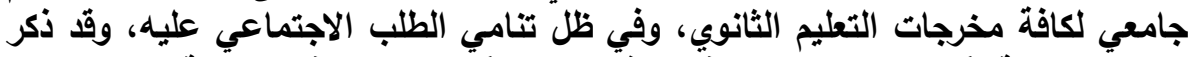

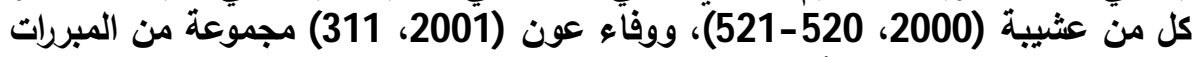
التي جعلت القطاع الخاص أحد مصادر التمويل البديلة للمصادر الرئيسة، ومنها:

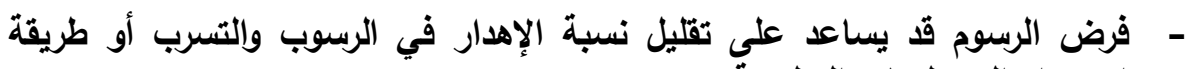
استخدام المستلزمات التعليمية.

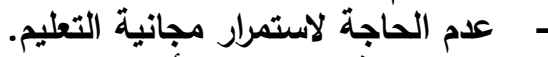

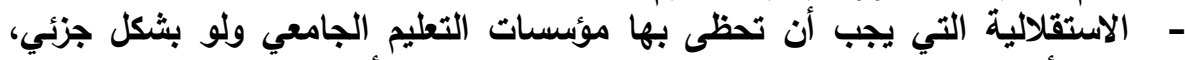

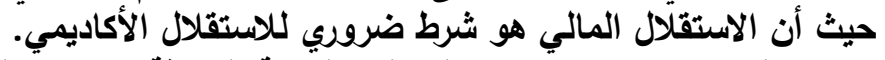

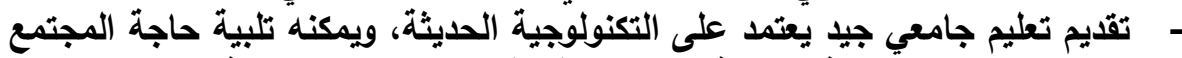

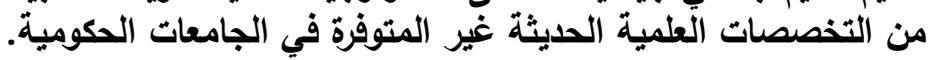




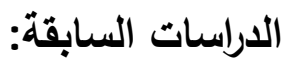

هناك دراسات وأبحاث علمية سعت تتناول واقع تمويل التعليم الجامعي ومنها

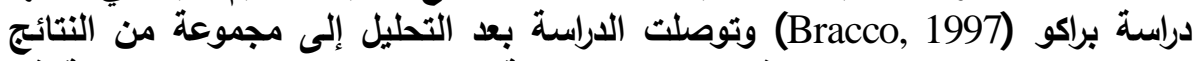

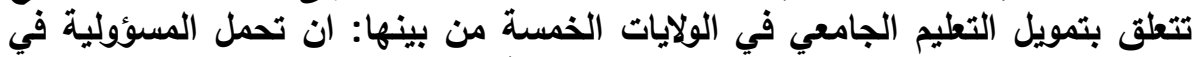

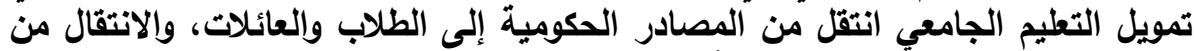

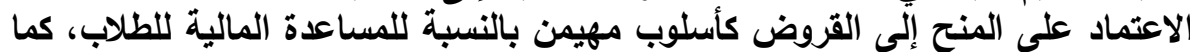

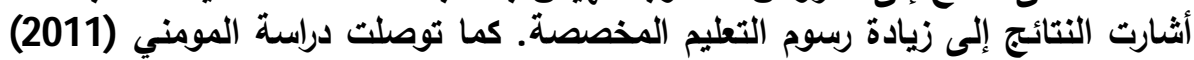

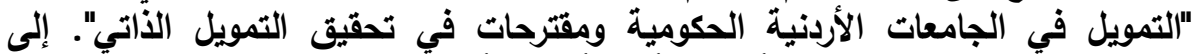

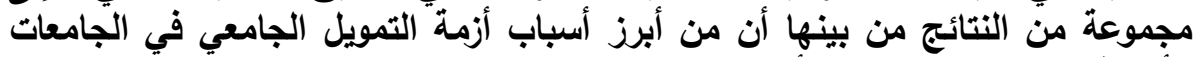

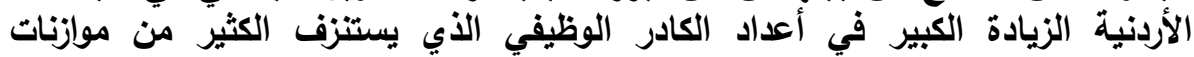

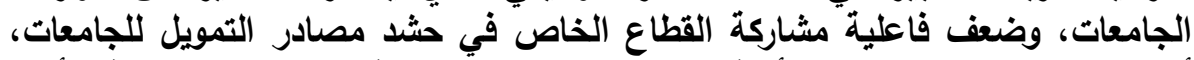

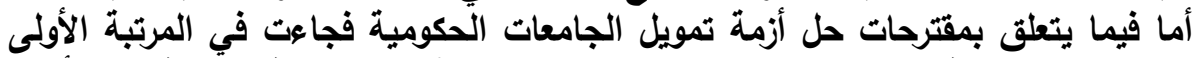

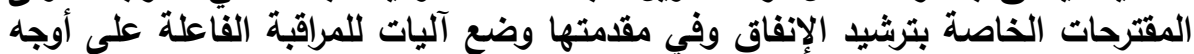

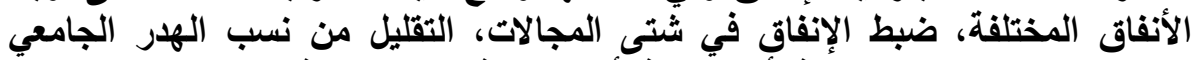

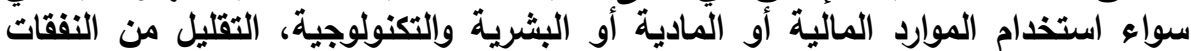

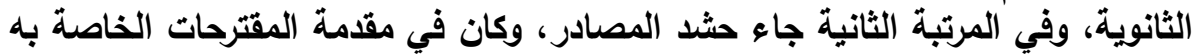

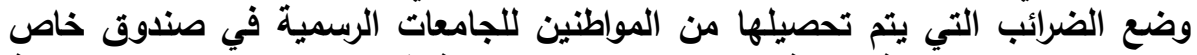

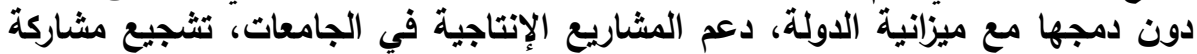

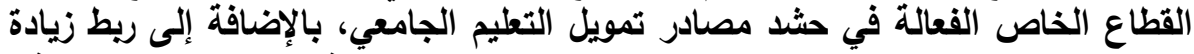

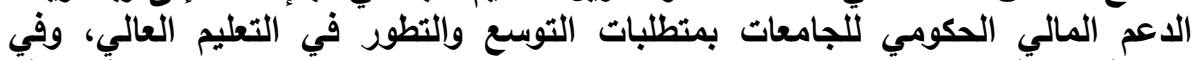

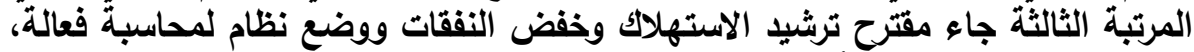

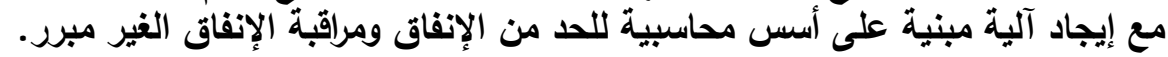

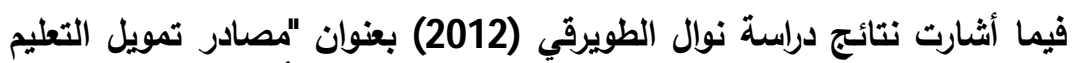

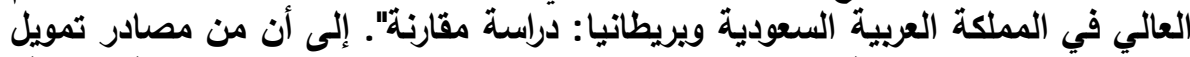

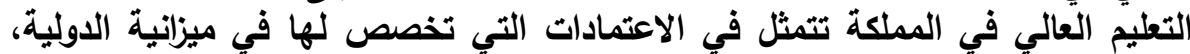

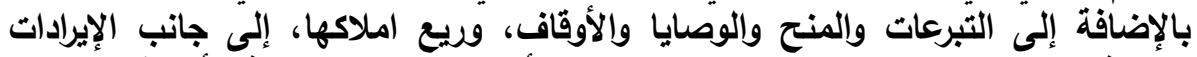

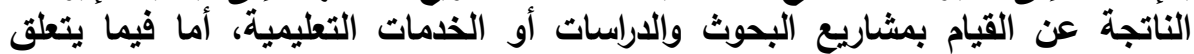

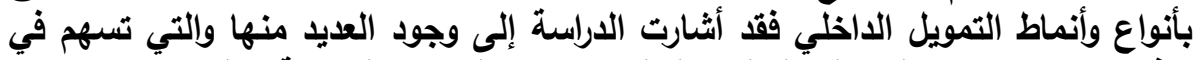

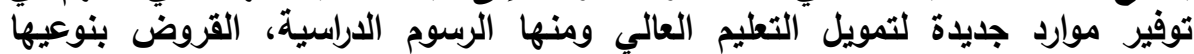

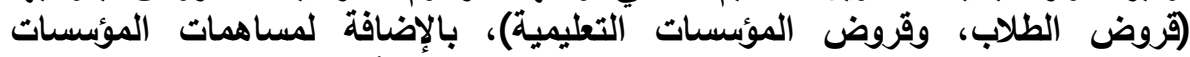

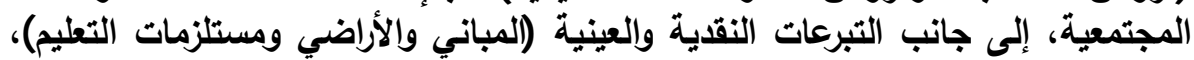

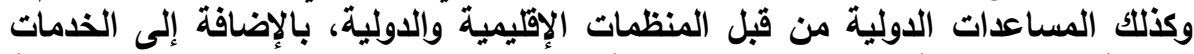

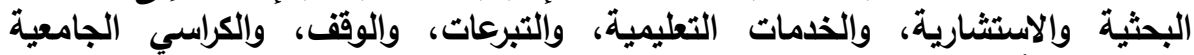

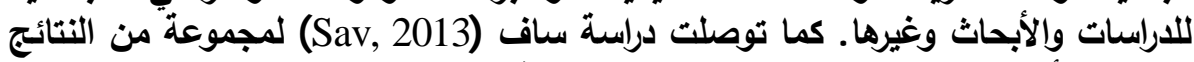

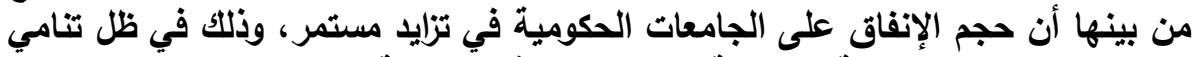

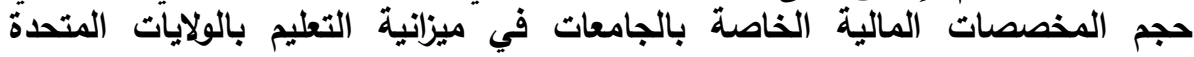


مجلة كلية التربية، جامعة الأزهر، العدد: (183، الجزء الثاني) يوليو لسنة 2019م

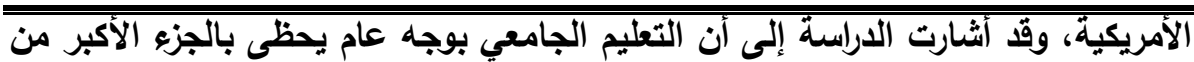

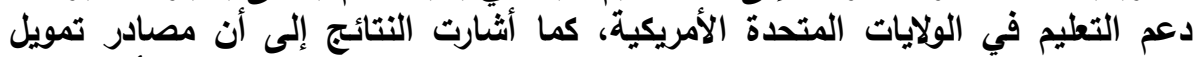

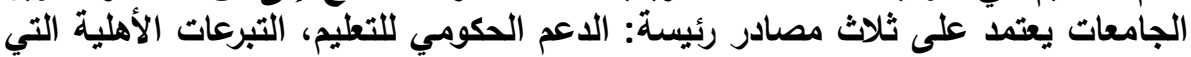

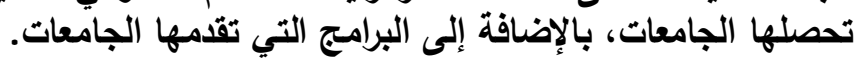

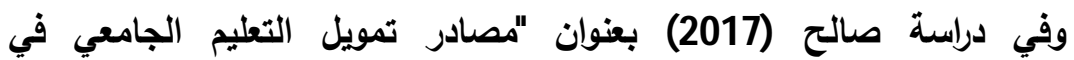

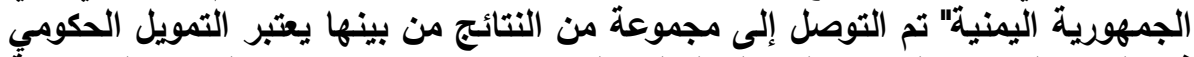

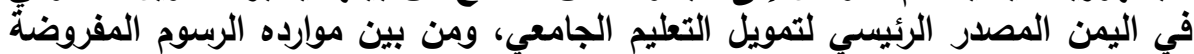

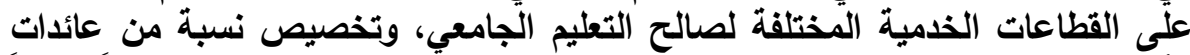

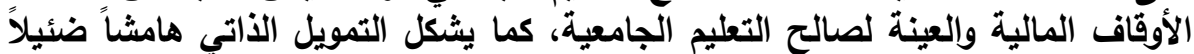

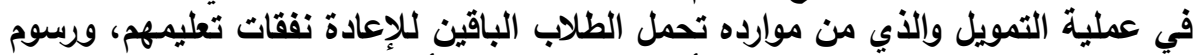

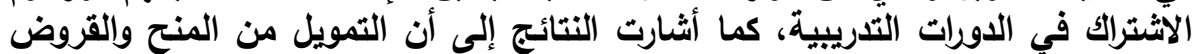

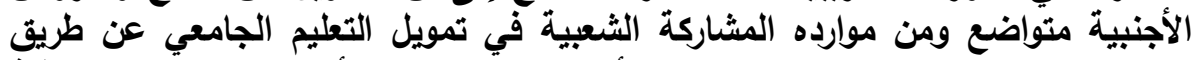

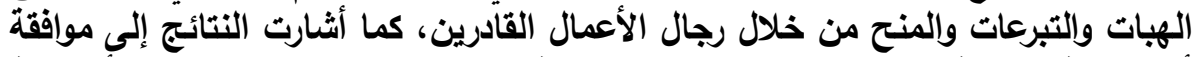

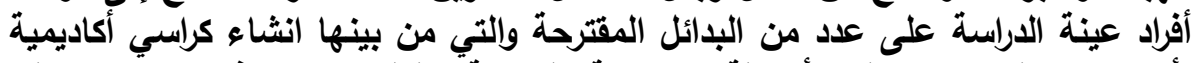

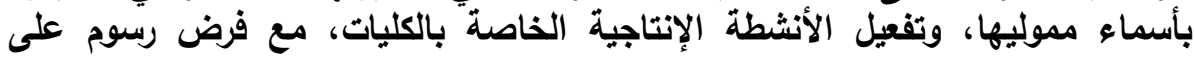
الإعلانات في وسائل الإعلام، ورسوم الخدمات الطلابية، وإيجار المرافقي. الاراسات التي تتناول بناء بدائل مقترحة لتمويل التعليم الجامعي: بداية توصلت دراسة الشامي (2006) عنوان "تصور مقترح لتطوير مصادر

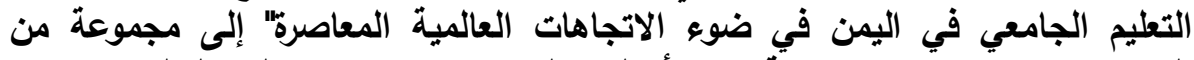

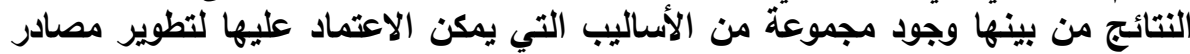

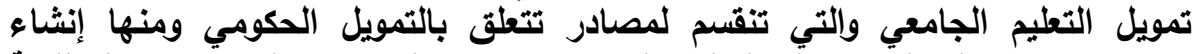

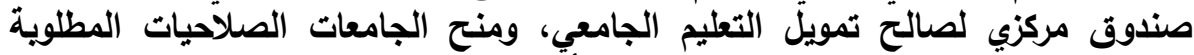

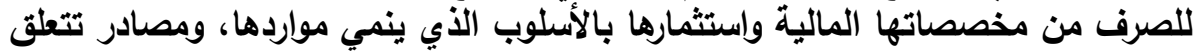

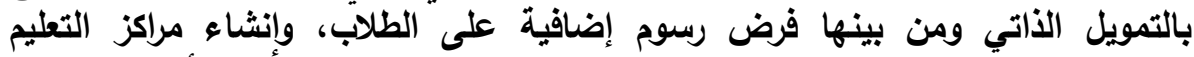

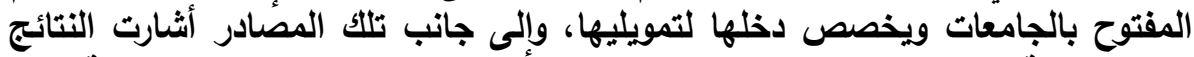

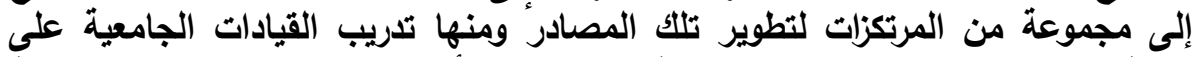

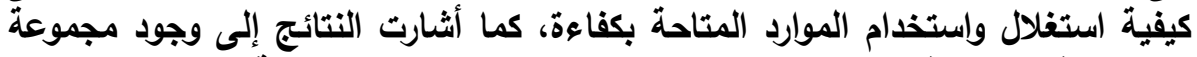

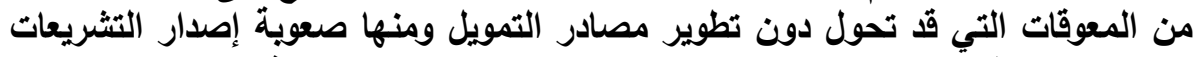

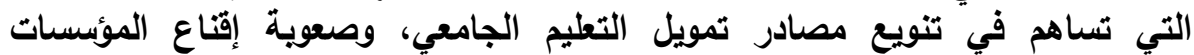
والثركات الخاصةّة للاخول في شراكة مع الجامعات في تمويل التعليم الجامعي.

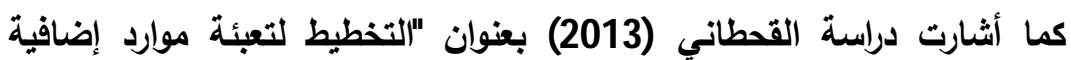

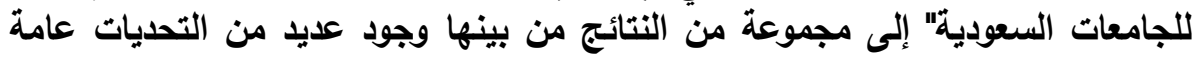

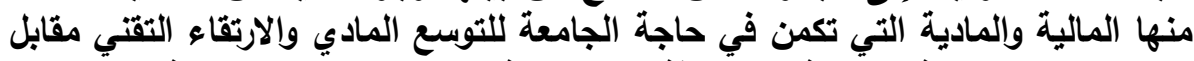

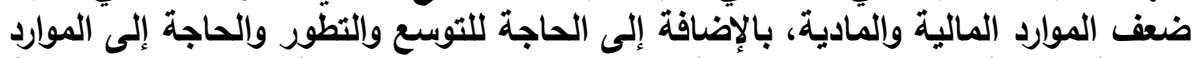

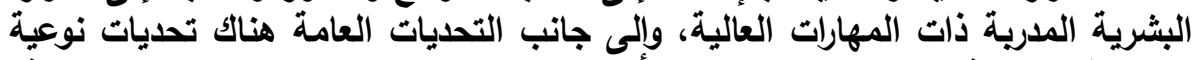

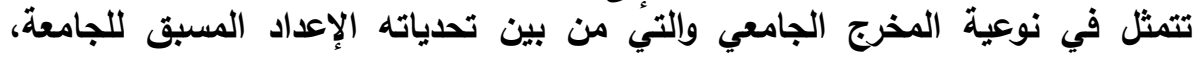


والمحتوى العلمي المقدم للطلاب في ظل الانفجار المعرفي والمعلومات المتغيرة والمتناقضة

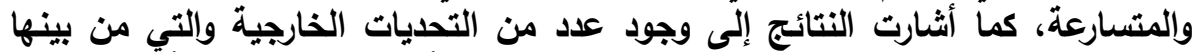

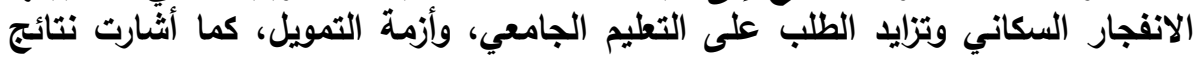

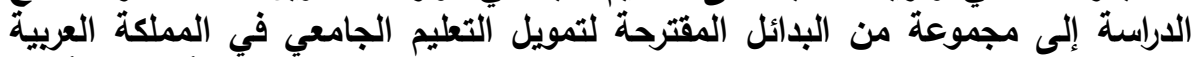

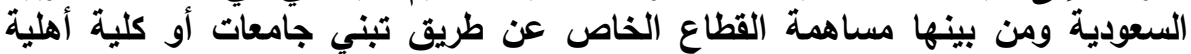

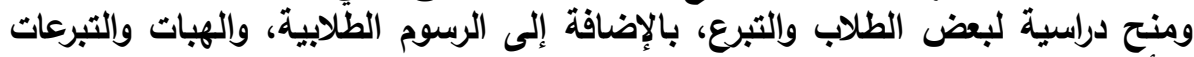
والأوقاف، والاستثمار في موارد وإمكانات.

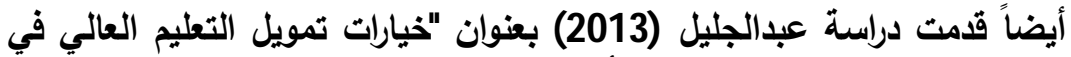

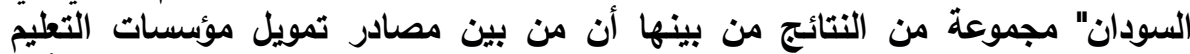

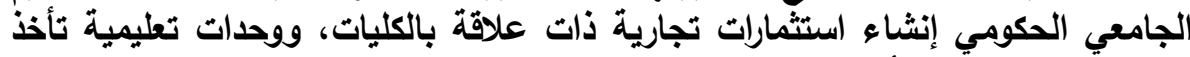

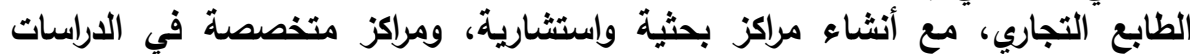

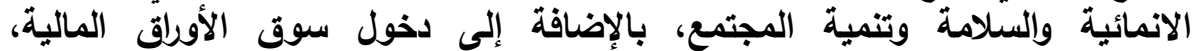

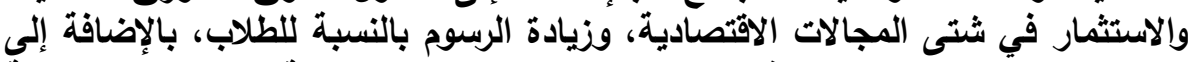

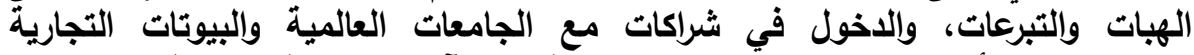

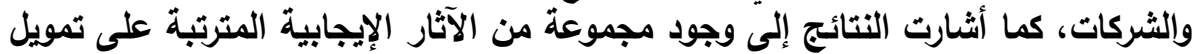

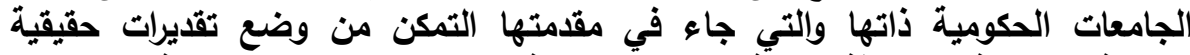

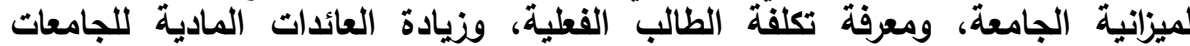

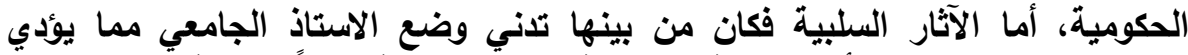

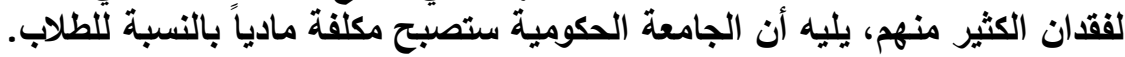
واظهرت دراسة أمل الحربي (2015) بعنوان "بدائل مقترحة لتمويل التعليم في دي

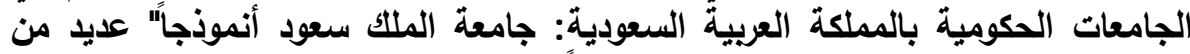

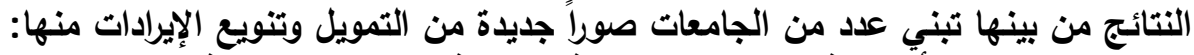

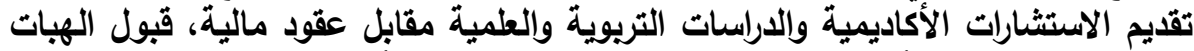

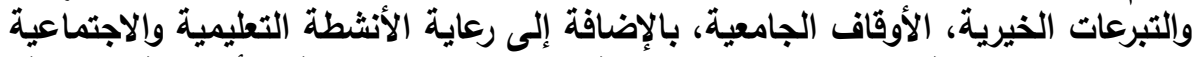

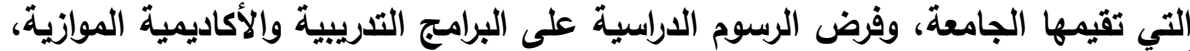

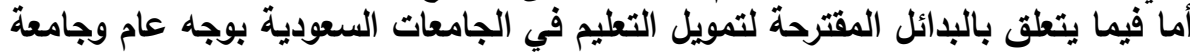

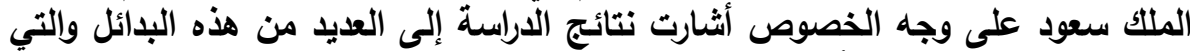

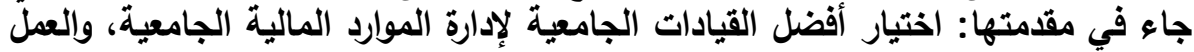

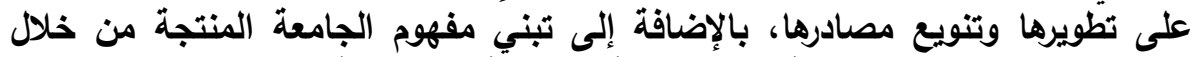

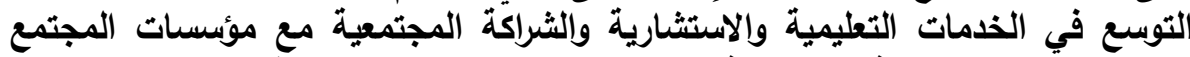

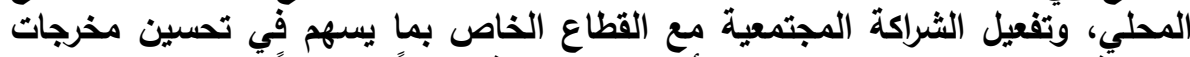

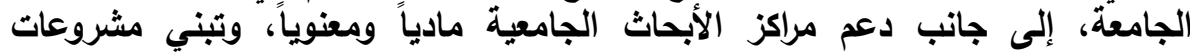
حاضنات الأعمال، مع العمل على التوسع في إنثاء كراسي البحث العاديات العلمي، وتقديم القروض الميسرة للطبة.

وأخيراً توصلت دراسة الثنيفي (2018) بعنوان "البدائل المقترحة لتمويل التعليم

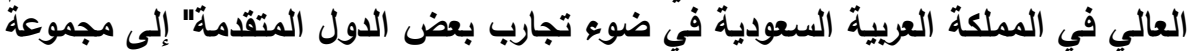


مجلة كلية التزبية، جامعة الأزهر ، العدد: (183، الجزء الثاني) يوليو لسنة 2019م

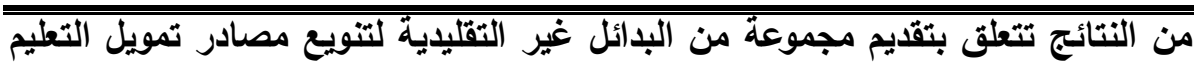

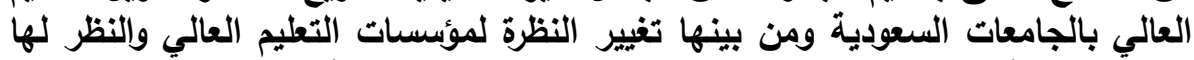

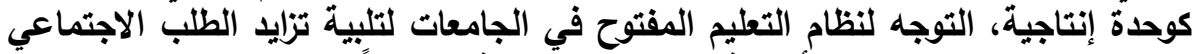

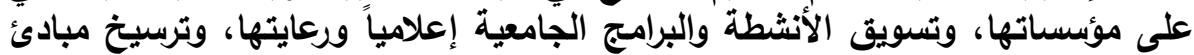

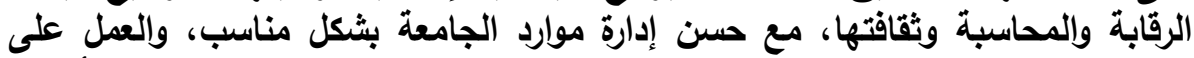

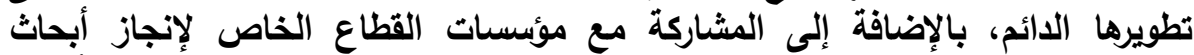

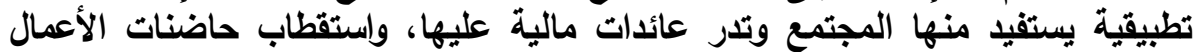

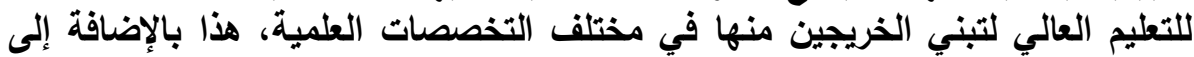

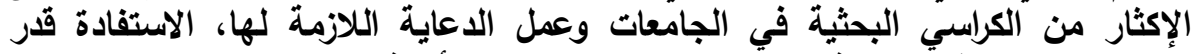

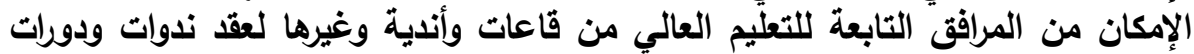

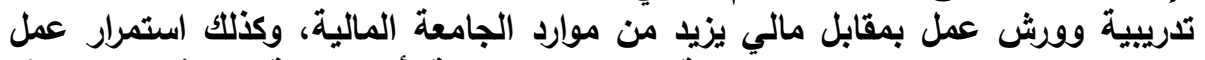

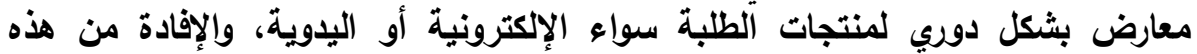

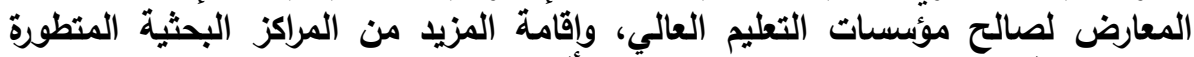
والمتخصصة والاستفادة من خبرات التعات اعضاء هيئة التدريس.

$$
\text { التعقيب على الاراسات السابقة: }
$$

1. أوجه الاتفاق والاختلاف بين الدراسات السابقة والاراسة الحالية:

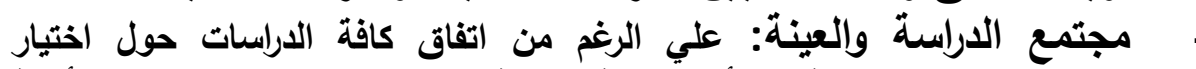

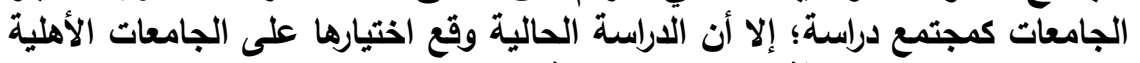

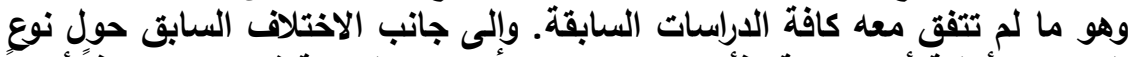

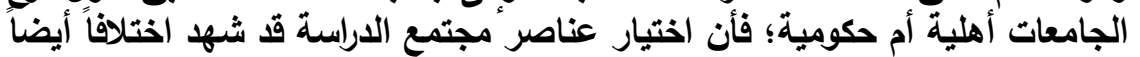

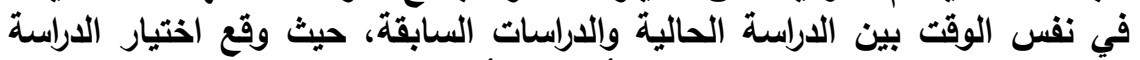

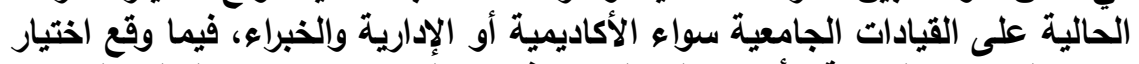

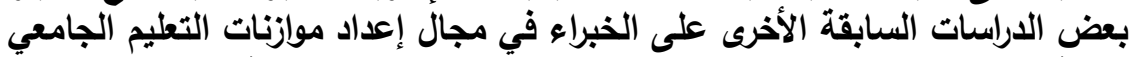

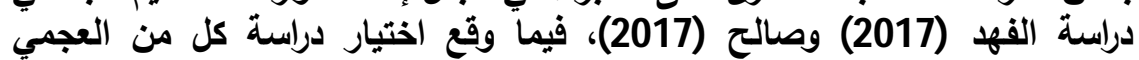

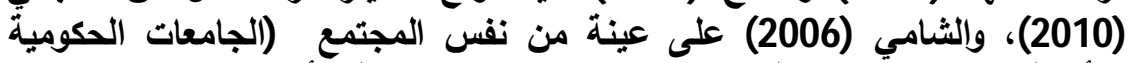

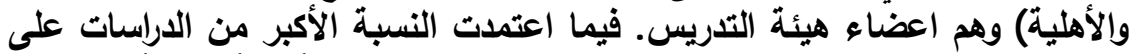

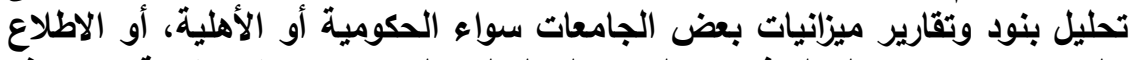

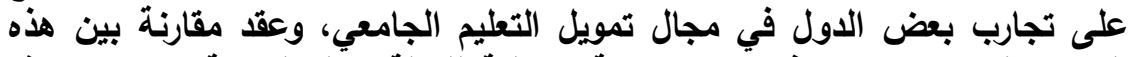

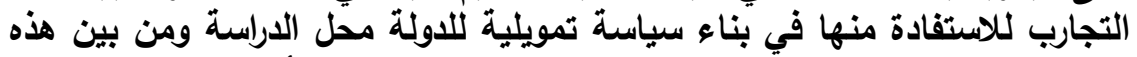

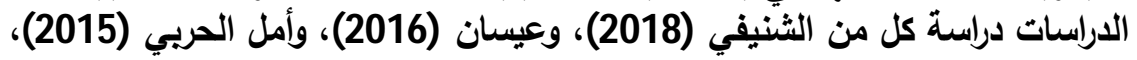

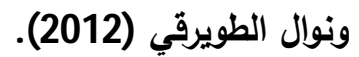

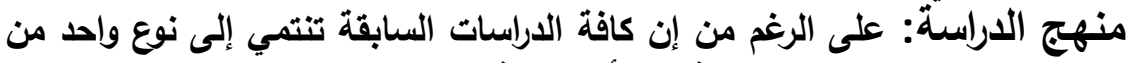

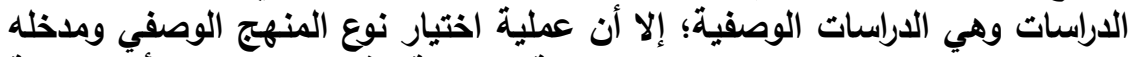

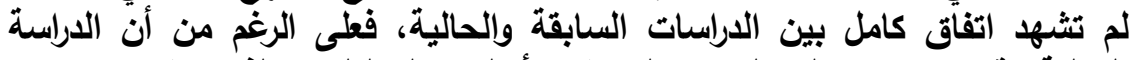

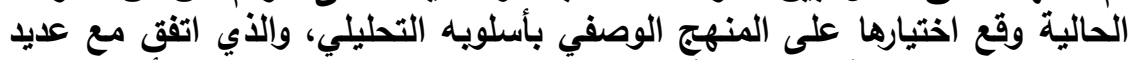

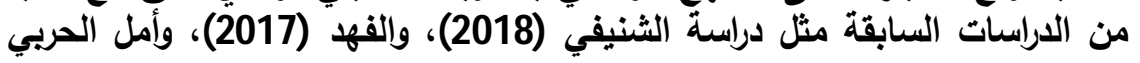


(2015)، وساف (Sav, 2013)؛ إلا أن هناك بعض الد الدراسات وقع اختيارها على وفي

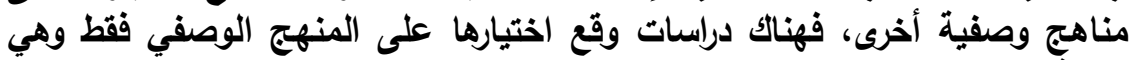

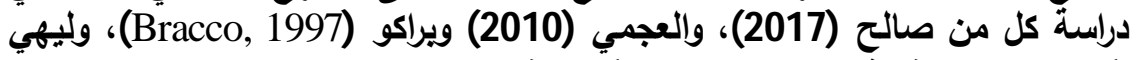

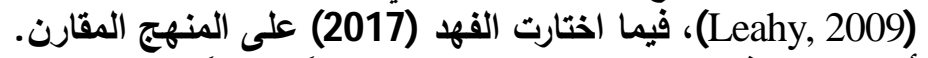

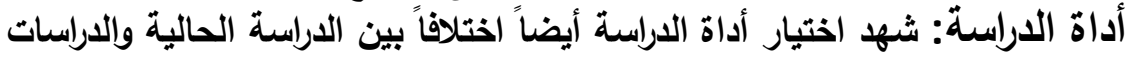

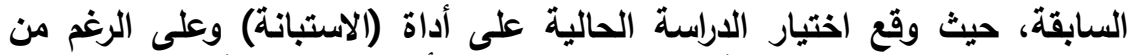

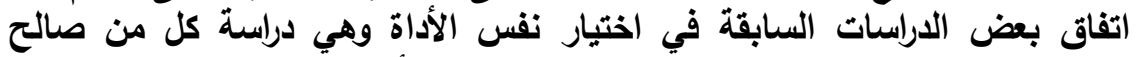

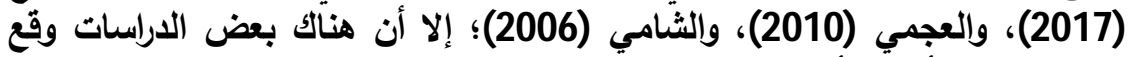

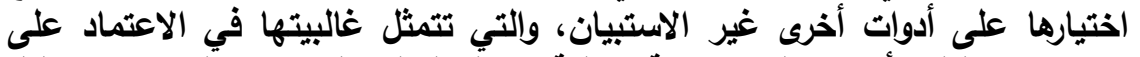

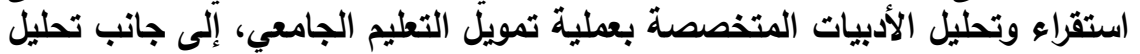

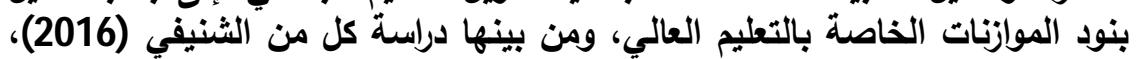

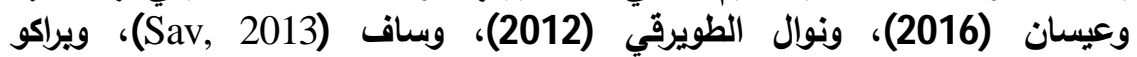

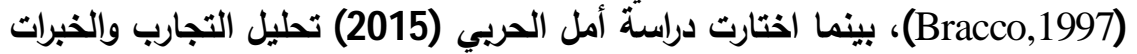
السابقة من خلال عقد مقارنة فيما بينها.

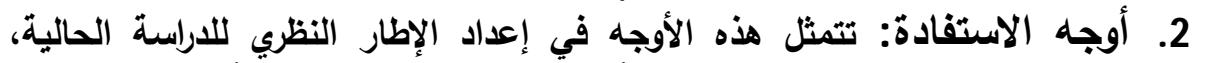

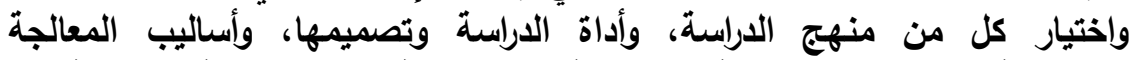

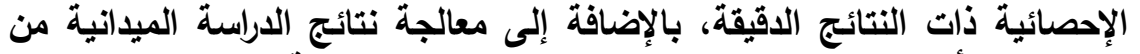

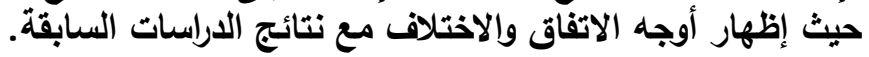

3. أوجه التميز: تتميز الدراسة الحالية عن باقي الدراسات السابقة في كونها تسعى الإبل

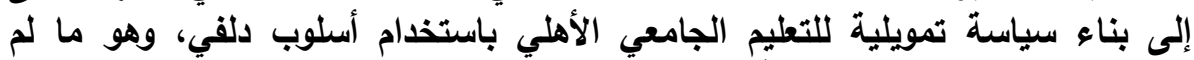
تتطرق لله باقي الدراسات السابقة. منهجية الدراسة واجراء|تها: أولاً: منهج الاراسة: نظراً لطبيعة موضوع الدراسة الحالية (بناء سياسة تمويلية

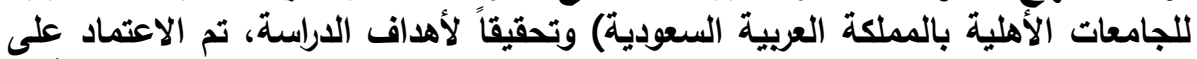

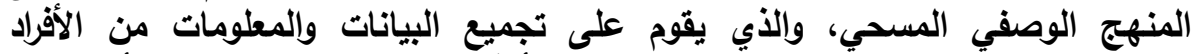
الممثلين لعينة الدراسة موضع البحث، وهذا يعني أنَّ عملية جمع المعلومات البهات تتأثر بتعدد

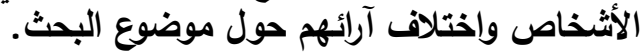

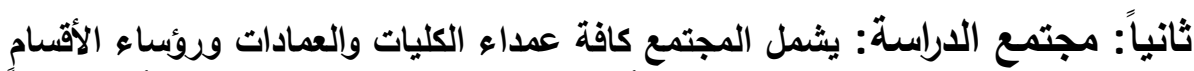

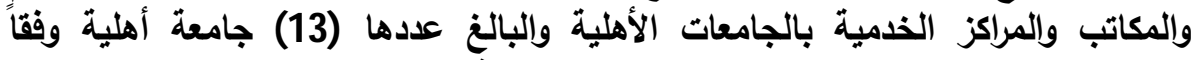

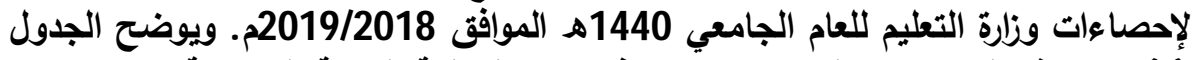
(1) عدد هذه الجامعات وكلياتها وتوزيعها في مدن المملكة العربية السعودية: 
مجلة كلية التربية، جامعة الأزهر ، العدد: (183، الجزء الثاني) يوليو لسنة 2019م

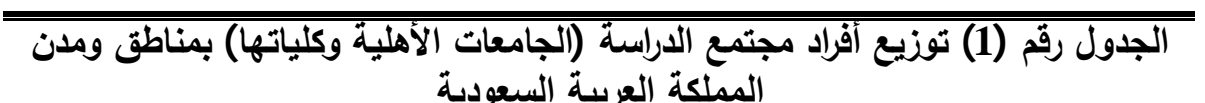

المملكة العربية السعودية

\begin{tabular}{|c|c|c|c|}
\hline 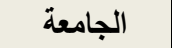 & المقر & 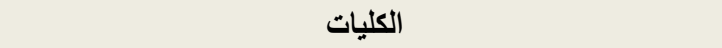 & م \\
\hline سلطان الأهليزة & 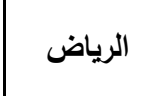 & كلية إدارة الأعمال - كلية علية القانوم الحاسبة ونظية العلوم الإنسانية. & .1 \\
\hline جامعة الفيصل & 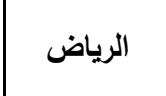 & 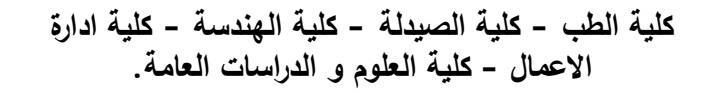 & .3 \\
\hline 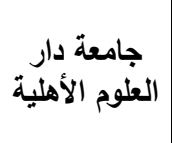 & 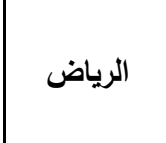 & 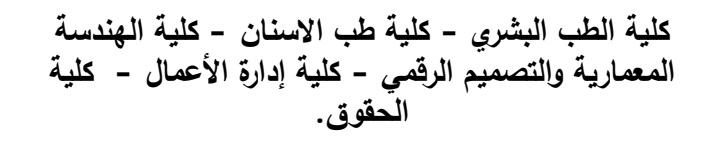 & .4 \\
\hline | الأهلية & 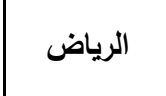 & كلية إدارة الأعمال - كلية الحاسب ونظم المعلومات - كلية & .5 \\
\hline جامعة العرفة & 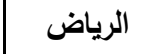 & كلية الطب - كلية الصيالة - كلية العلوم التطبيقية & .6 \\
\hline جامعة رياض & 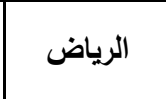 & كلية طب الأسنان - كلية التمريض - كلية التوبة الصيلة - كلية & .7 \\
\hline المفامعة المبية & الألدة، الأمام، المناض، & إدارة الأعمال - تقتية المعلومات والحوسبة - الدراسات اللغوية. & .8 \\
\hline عبدامعة الله للعلوم & 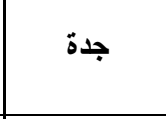 & 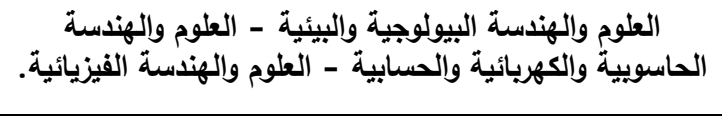 & .9 \\
\hline جامعة عفت & 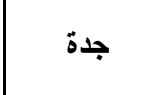 & كلية الهندسة - كلية الأعمال - كلية العلوم الانسانية & .10 \\
\hline جامعة دار & 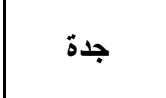 & كلية إدارة الأعمال والقانون - كلية التصمية والعمارة - كلية & .11 \\
\hline 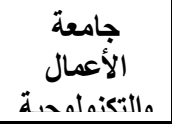 & 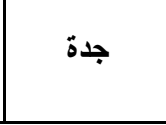 & كلية إدارة الأعمال - كلية الهندسة - كلية الإعلان - كلية & .12 \\
\hline
\end{tabular}


مجلة كلية التربية، جامعة الأزهر، العدد: (183، الجزء الثاني) يوليو لسنة 2019م

\begin{tabular}{|c|c|c|c|}
\hline الجامعة & المقر & الكليات & م \\
\hline جمامعة الأمير & الخبر & 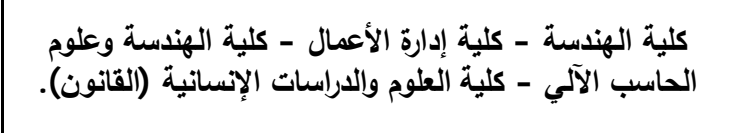 & .13 \\
\hline جرامعة الأمير & 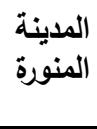 & كلية الهندة - كلية إدارة الأعمال - كلية الحاسب الآلي وتقتية & .14 \\
\hline جامعة الأميز & تبوك & 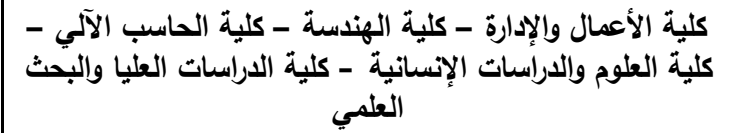 & .15 \\
\hline
\end{tabular}

ثالثاً: عينة الدراسة: نظراً لاتساع النطاق الجغرافي لمجتمـع الدراسـة (الجامعات الأهلية)

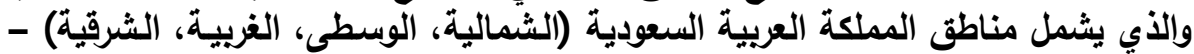

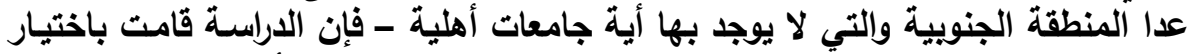

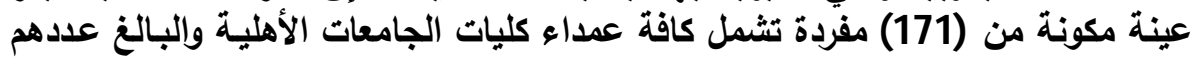

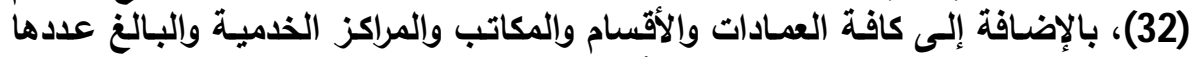

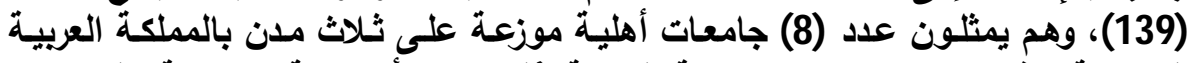

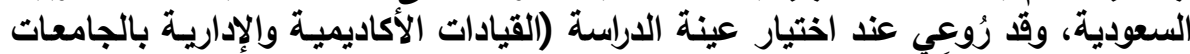

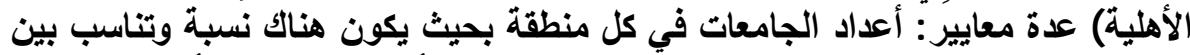

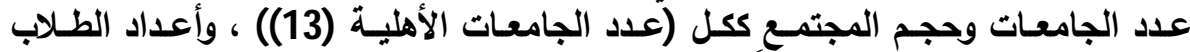

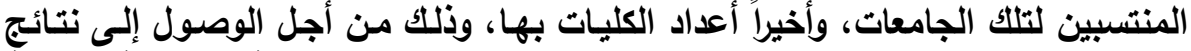

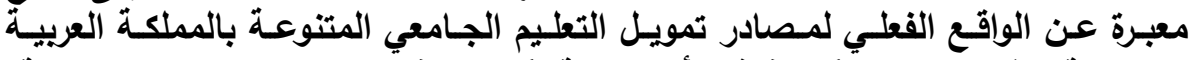

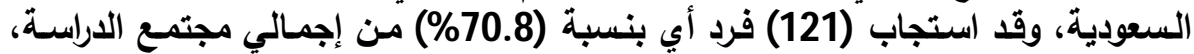

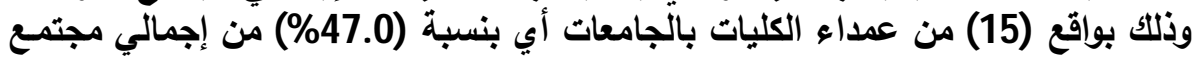

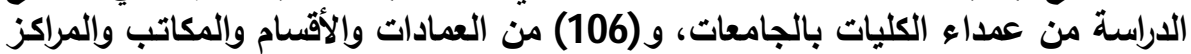

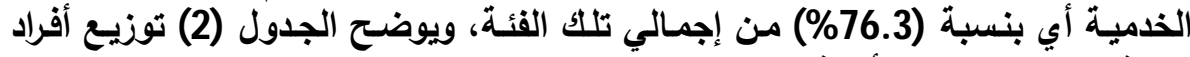
العينة على الجامعات الأهلية وكلياتها. 
مجلة كلية التربية، جامعة الأزهر ، العدد: (183، الجزء الثاني) يوليو لسنة 2019م

\begin{tabular}{|c|c|c|c|c|c|}
\hline \multicolumn{6}{|c|}{ 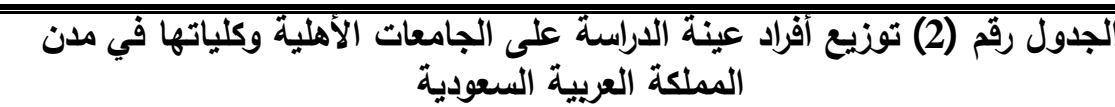 } \\
\hline \multirow{2}{*}{ الإجمالي } & \multicolumn{2}{|c|}{ العمادات/الإداراتات/ الأقُّسام } & \multicolumn{2}{|c|}{ بالجامعات الأهلياتة } & \multirow[t]{2}{*}{ الجامعة } \\
\hline & الاستجابات & الإجمالي & |لاستجابات & إلإجمالي & \\
\hline 27 & 17 & 22 & 2 & 5 & جامعة الأمير سلطان الأهلية \\
\hline 10 & 4 & 7 & 1 & 3 & جامعة اليمامة الأهلية \\
\hline 43 & 32 & 38 & 2 & 5 & جامعة الفيصل الأهلية \\
\hline 26 & 17 & 21 & 3 & 5 & جامعة دار العلوم الأهلية \\
\hline 15 & 8 & 12 & 2 & 3 & الجامعة العربيةٌ المفتوحة \\
\hline 15 & 7 & 11 & 2 & 4 & جامعة عفت الأهلية \\
\hline 14 & 8 & 11 & 1 & 3 & جامعة الملك عبدالله للعظوم \\
\hline 21 & 13 & 17 & 2 & 4 & جامعة الأمير محمد بن فهلة \\
\hline 171 & 106 & 139 & 15 & 32 & الإجمالى \\
\hline
\end{tabular}

رابعاً: أداة الاراسة (الاستبانة): مر بناء الاستبانة بثلاث مراحل، وذلك على النحو

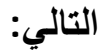

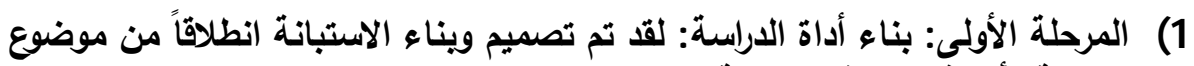

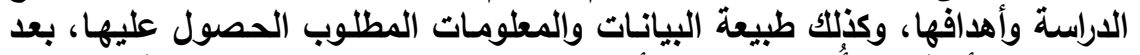

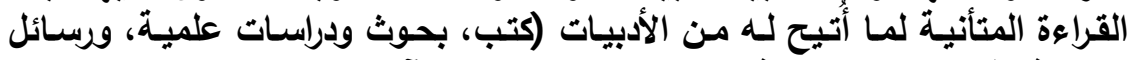

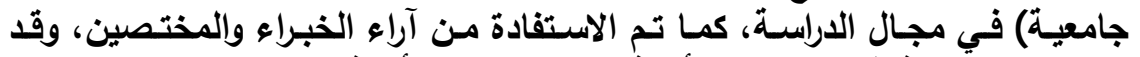

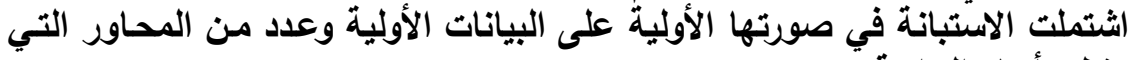

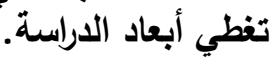

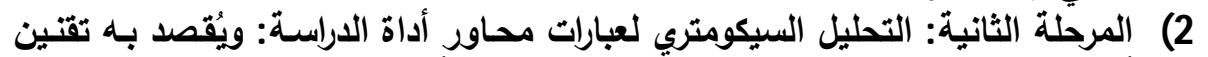

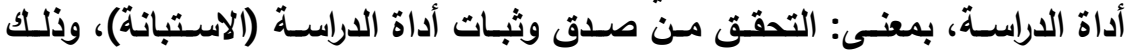

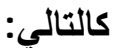

صدق الأداة (الاستبانة): يُقصد بصدق الأداة "التحقق من شمول الاستمارة

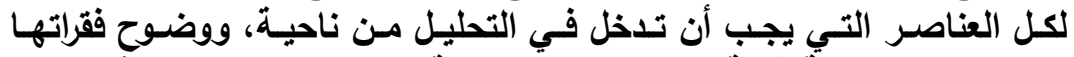

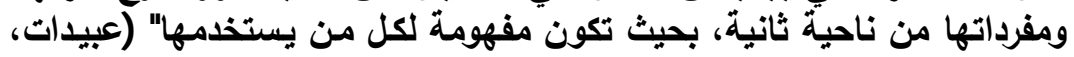

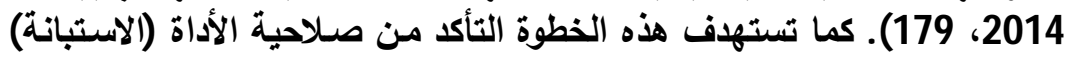

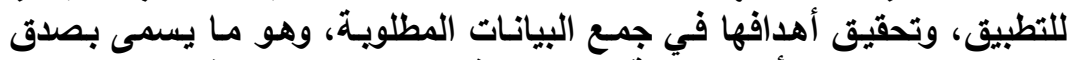

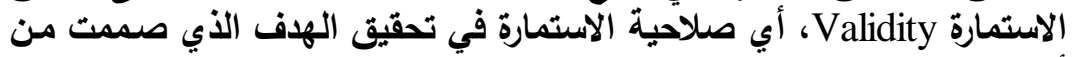

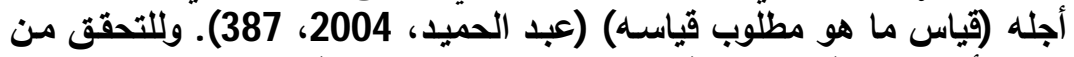
صدق أداة الدراسة (الاستبانة) تم إجراء الاختبارات التالية: التميد، 
- صدق المحكمين (الصدق الظاهري): تم عرض أداة الدراسة (الاستبانة) على عداد

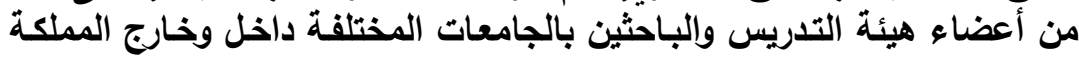

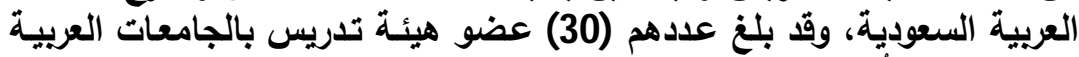

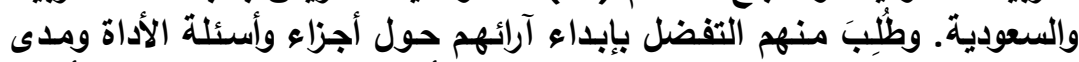

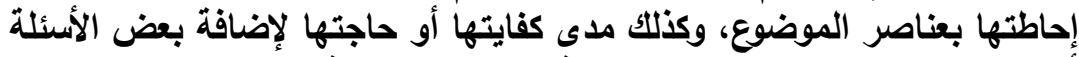

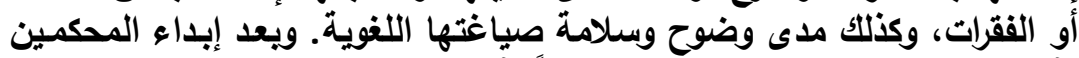

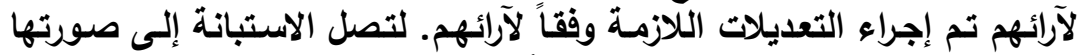

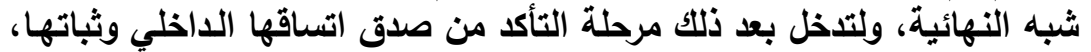

$$
\text { وذلك على النحو التالي: }
$$

الاتساق الاخلي: ويقصد به التحقق من صدق أداة الدراسة (الاستبانة)

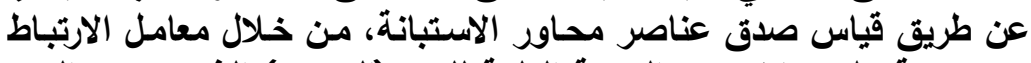

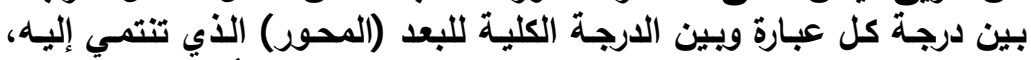

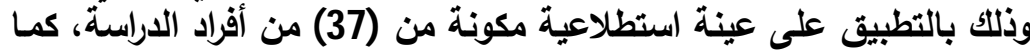
هو موضح في الجداول من رقم ( 3 إلى 4)، وذلك منك على النى النحو التالي: جدول رقم (3) معاملات ارتباط بيرسون لعبارات محور (واقع تمويل الجامعات الأهلية في

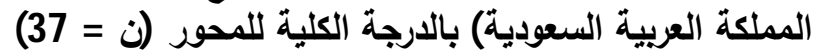

\begin{tabular}{|c|c|c|c|}
\hline معامل الارتباط & العبارة & معامل الارتباط & العبارة \\
\hline$* * 0.676$ & 8 & $* * 0.531$ & 1 \\
\hline$* * 0.529$ & 9 & $* * 0.692$ & 2 \\
\hline$* * 0.737$ & 10 & $* * 0.651$ & 3 \\
\hline$* * 0.482$ & II & $* * 0.529$ & 4 \\
\hline$* * 0.760$ & 12 & $* * 0.653$ & 5 \\
\hline$* * 0.682$ & 13 & $* * 0.679$ & 6 \\
\hline - & - & $* * 0.710$ & 7 \\
\hline
\end{tabular}

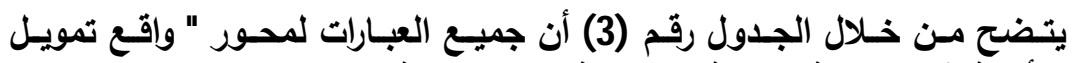

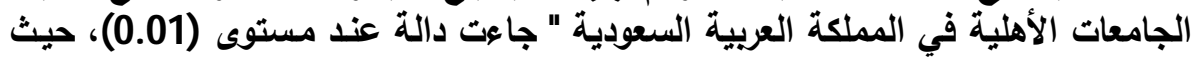

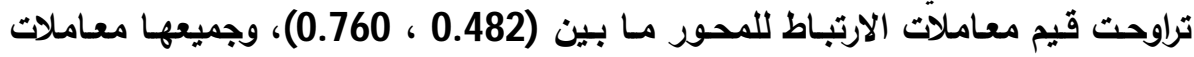

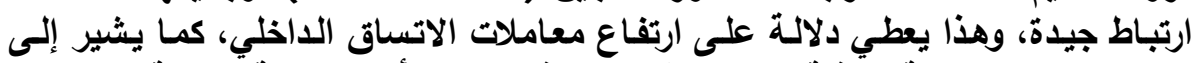

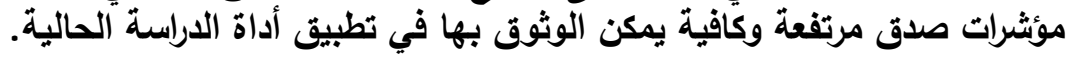


مجلة كلية التربية، جامعة الأزهر ، العدد: (183، الجزء الثاني) يوليو لسنة 2019م

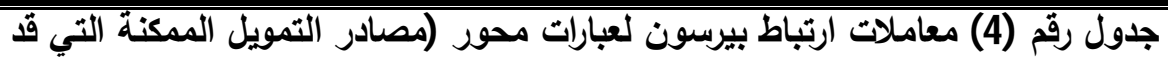

تُُهم في تنوع مصادر تمويل الجامعات الأهلية) بالارجة الكلية للمحور (ن = 37)

\begin{tabular}{|c|c|c|c|c|c|c|c|}
\hline \multicolumn{2}{|c|}{ المصدر الرابع } & \multicolumn{2}{|c|}{ المصدر الثالث } & \multicolumn{2}{|c|}{ المصدر الثاني } & \multicolumn{2}{|c|}{ المصدر الأول } \\
\hline معامل & العبارة & معامل & العبارة & معامل & العبارة & معامل & العبارة \\
\hline$* * 0.801$ & I & $* * 0.757$ & 1 & $* * 0,460$ & $\mathbf{I}$ & $* * 0.549$ & 1 \\
\hline **0.768 & 2 & $* * 0.729$ & 2 & $* * 0.662$ & 2 & $* * 0.504$ & 2 \\
\hline$* * 0.821$ & 3 & $* * 0.607$ & 3 & $* * 0.740$ & 3 & $* * 0.690$ & 3 \\
\hline$* * 0.739$ & 4 & $* * 0.764$ & 4 & $* * 0.748$ & 4 & $* * 0.535$ & 4 \\
\hline$* * 0.701$ & 5 & $* * 0.669$ & 5 & $* * 0.660$ & 5 & $* * 0.592$ & 5 \\
\hline$=$ & - & $* * 0.728$ & 6 & $* * 0.706$ & 6 & $* * 0.592$ & 6 \\
\hline - & - & $* * 0.769$ & 7 & $* * 0.615$ & 7 & $* * 0.676$ & 7 \\
\hline
\end{tabular}

جدول رقم (5) معاملات ارتباط بيرسون لأبعاد محور (مصادر التمويل الممكنة التي قد الدالئ تُُهم في تنوع مصادر تمويل الجامعات الأهلية) بالدرجة الكلية للمحور (ن = 37)

\begin{tabular}{|c|c|}
\hline معامل الارتباط & 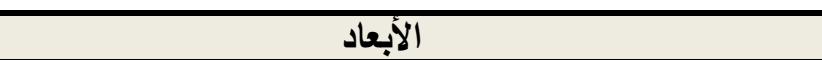 \\
\hline$* * 0.802$ & المصدر الأول: مساهمة الخدمات التعليميةٌ في تمويل التعليم \\
\hline$* * 0.869$ & المصدر الثاني: مساهمة القطاع الخاص في تمويل التعليم \\
\hline$* * 0.920$ & المصدر الثالث: مساهمةٌ الجامعُة المنتجة فِي تمويل التعليم \\
\hline$* * 0.880$ & المصدر الرابع: مساهمة الوقق والمساعدات فِي تمويل التعليم \\
\hline
\end{tabular}

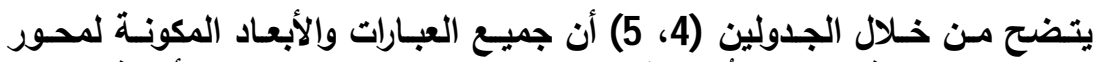

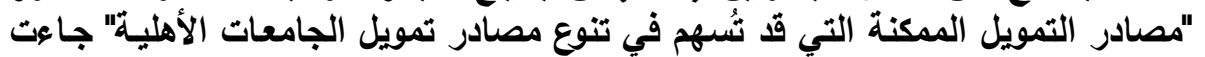

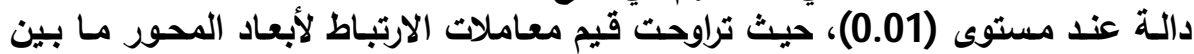

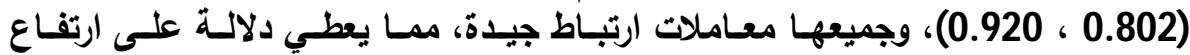

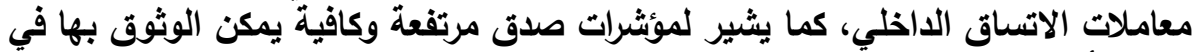
تطبيق أداة الاراسة الحالية.

جدول رقم (6) معاملات ارتباط بيرسون لعبارات محور (معوقات تمويل الجامعات الأهلية

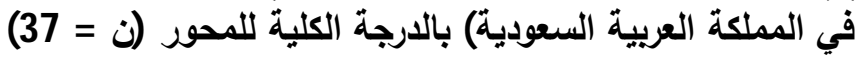

\begin{tabular}{|c|c|c|c|c|c|c|c|}
\hline \multicolumn{2}{|c|}{ معوقات مساهمةٌ الوقف } & \multicolumn{2}{|c|}{ معوقات مساهمـة } & \multicolumn{2}{|c|}{ معوقات مساهمة } & \multicolumn{2}{|c|}{ معوقات الاستفادة من } \\
\hline معامل الارتباط & العبارة & معامل & العبارة & معامل & عـ & معامل الارتباط & العبارة \\
\hline$* * 0.699$ & 1 & $* * 0.763$ & 1 & $* * 0.676$ & 1 & $* * 0.545$ & $\mathbf{I}$ \\
\hline$* * 0.695$ & 2 & $* * 0.720$ & 2 & $* * 0.731$ & 2 & $* * 0.585$ & 2 \\
\hline$* * 0.709$ & 3 & $* * 0.710$ & 3 & $* * 0.658$ & 3 & $* * 0.641$ & 3 \\
\hline$* * 0.733$ & 4 & $* * 0.606$ & 4 & $* * 0.779$ & 4 & $* * 0.669$ & 4 \\
\hline 8 & 5 & $* * 0605$ & 5 & **0650 & 5 & **ก551 & 5 \\
\hline
\end{tabular}


مجلة كلية التربية، جامعة الأزهر، العدد: (183، الجزء الثاني) يوليو لسنة 2019م

\begin{tabular}{|c|c|c|c|c|c|c|c|}
\hline \multicolumn{2}{|c|}{ معوقات مساهمة الوقف } & \multicolumn{2}{|c|}{ معوقات مساهمة } & \multicolumn{2}{|c|}{ معوقات مساهمة } & \multicolumn{2}{|c|}{ معوقات الاستفادة من } \\
\hline |معامل الارتباط| & العبارة & معامل - معل & العبارة & 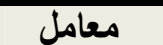 & 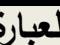 & معامل الارتباط & العبارة \\
\hline$* * 0.670$ & $\dot{6}$ & $* * 0.695$ & $\dot{6}$ & $* * 0.751$ & $\dot{6}$ & $* * 0.567$ & $\dot{6}$ \\
\hline$* * 0.809$ & 7 & - & - & $* * 0.720$ & 7 & $* * 0.569$ & 7 \\
\hline - & $=$ & - & $=$ & $=$ & - & $* * 0.602$ & 8 \\
\hline - & - & - & - & - & $=$ & $* * 0.639$ & 9 \\
\hline
\end{tabular}

دال عند مستوى (0.01)

جدول رقم (7) معاملات ارتباط بيرسون لأبعاد محور (معوقات تمويل الجامعات الأهلية في

المملكة العربية السعودية) بالارجة الكلية للمحور (ن الن = 37 )

\begin{tabular}{|c|c|}
\hline معامل الارتباط & الأبعاد \\
\hline$* * 0.798$ & معوقات الاستفادة من الخدمات التعليميةٌ في تمويل التعليمِ \\
\hline$* * 0.903$ & معوقّات مساهمةٌ القطاع الخاص في تمويل التُعليم الجامعي \\
\hline$* * 0.889$ & 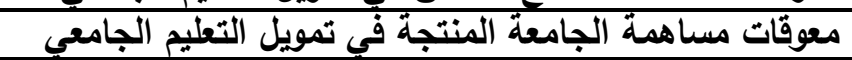 \\
\hline$* * 0.909$ & معوقات مساهمة الوقف والمساعدات الداخلية في تمويل التعليم \\
\hline
\end{tabular}

دال عند مستوى (0.01)

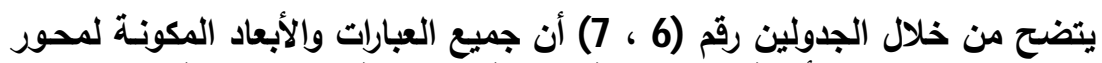

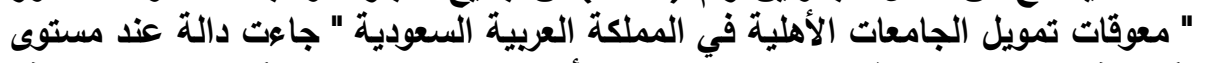

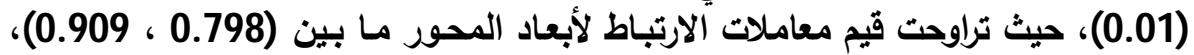

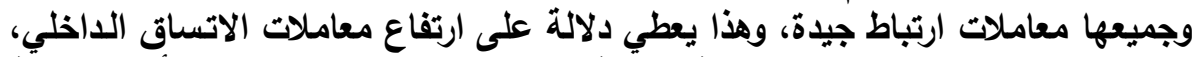

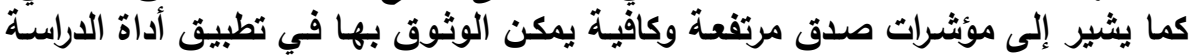

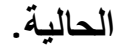

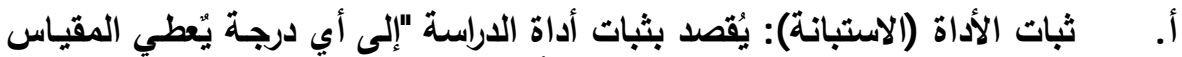

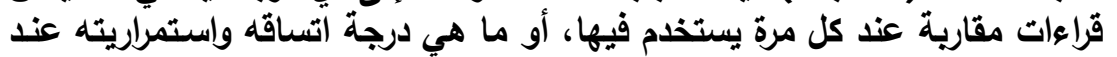

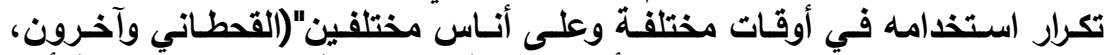

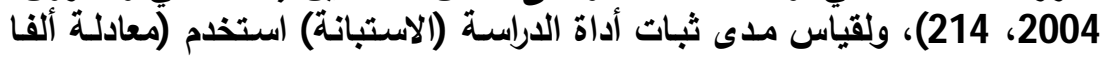

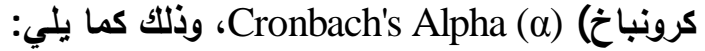


مجلة كلية التربية، جامعة الأزهر ، العدد: (183، الجزء الثاني) يوليو لسنة 2019م جدول رقم (8) معامل ألفاكرونباخ لقياس ثبات الاستبانة

\begin{tabular}{|c|c|c|c|}
\hline 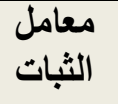 & 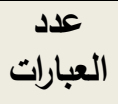 & المحور & b \\
\hline 0.875 & 13 & 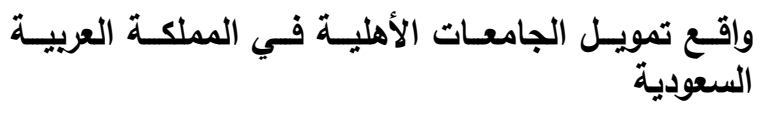 & 1 \\
\hline 0.766 & 7 & 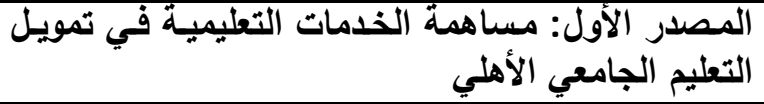 & 2 \\
\hline 0.871 & 7 & التعليم الجامعي الأهلي مساهمة القطـاع الخـاص في تمويـل & 3 \\
\hline 0.847 & 7 & التعليم الجامعي الأهلثي مساهمة الجامعـة المنتجـة في تمويـل & 4 \\
\hline 0.821 & 5 & التعليم الجامعي الأهليع: المساهمة الوقف والمساعدات في تمويل & 5 \\
\hline 0.893 & 26 & 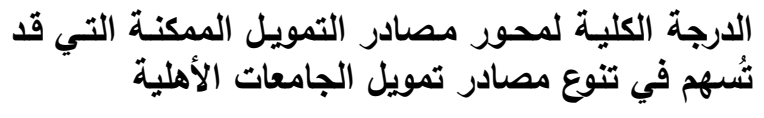 & 6 \\
\hline 0.808 & 9 & 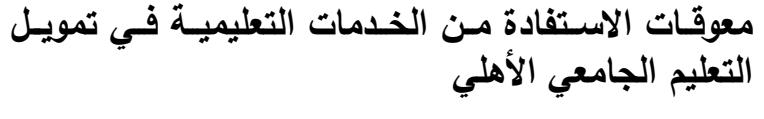 & 7 \\
\hline 0.895 & 7 & الجامعي الأهلي مستهـة القطـاع الخـاص فـي تمويـل التعلـيم & 8 \\
\hline 0.861 & 6 & الجامعي الأهلي مساهمة الجامعـة المنتجـة في تمويـل التعلـيم & 9 \\
\hline 0.894 & 7 & التعليم الجامعي الأهلي الوقف والمساعدات الداخلية في تمويل & 10 \\
\hline 0.848 & 29 & المملكة العربية الكليـة لمعوقـات تمويـل الجامعـات الأهليـة في & 11 \\
\hline 0.919 & 68 & الثبات الكلي & \\
\hline
\end{tabular}


يتضح من خـلال الجدول رقم (8) أن مقيـاس الدراسـة (الاستبانة) يتمتـع بثبـات

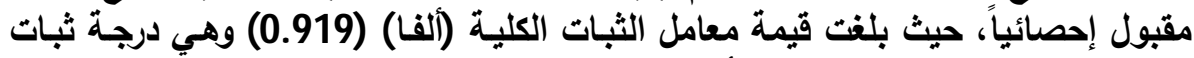

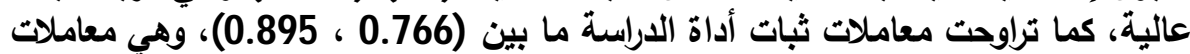

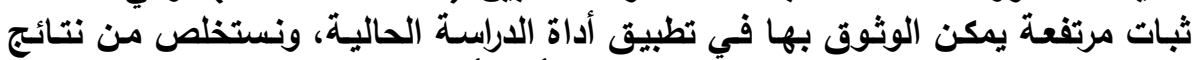

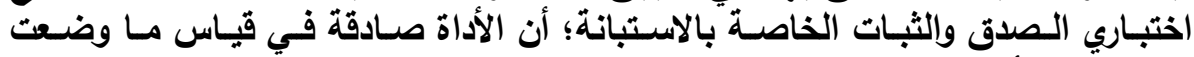
لقياسه، كما أنها ثابتة بلرجة جيات الثاهة

3) المرحلـة الثالثة: إخـراج ووصـف أداة الدراسـة (الاسـتبانة) في صسورتها النهائية: (المرجة:

تكونت أداة الدراسة (الاستبانة) في صورتها النهائية من قسمين هما:

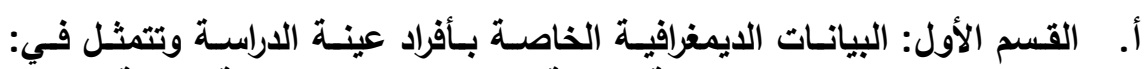

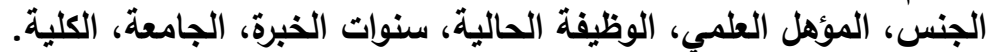

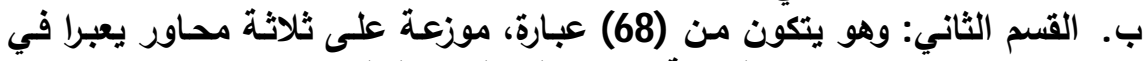
مضمونهز عن تساؤلات الدراسة، وهي على على النحو التالي: - المحور الأول: يتناول واقع تمويل الجامعات الأهلية في المملكة العربية السعودية،

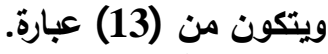

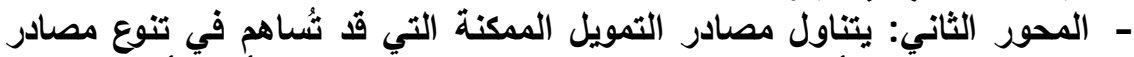

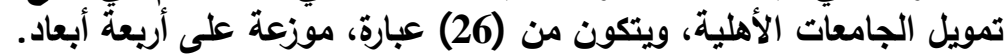

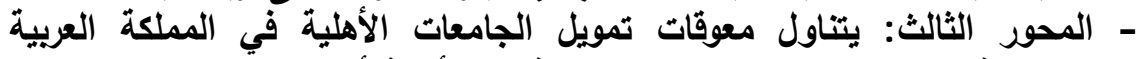

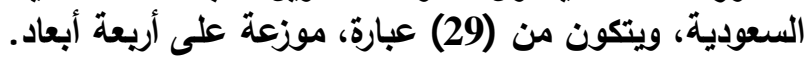

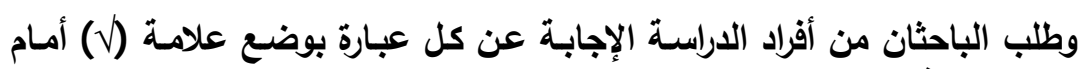

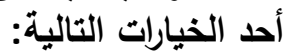

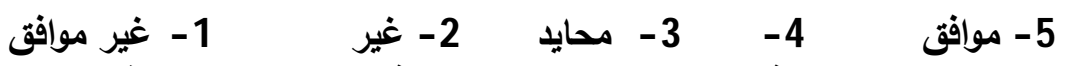

$$
\begin{aligned}
& \text { بشدة }
\end{aligned}
$$

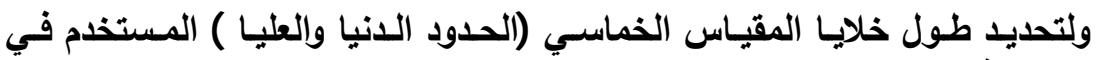

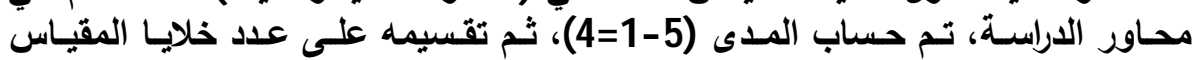

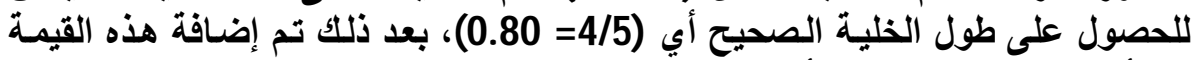

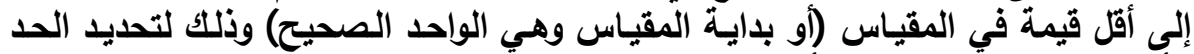

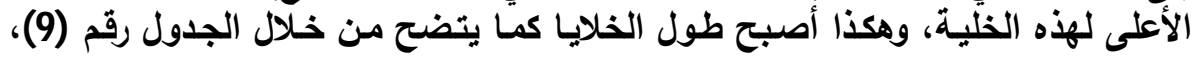

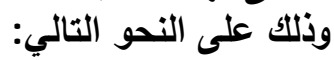


مجلة كلية التربية، جامعة الأزهر، العدد: (183، الجزء الثاني) يوليو لسنة 2019م

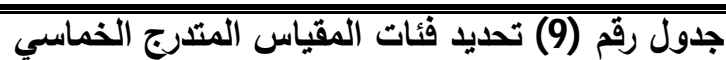

\begin{tabular}{|c|c|c|c|c|}
\hline غير موافق بشدة & غير موافق & محايد & موافق & موافق بشدة \\
\hline $1.80-1$ & $2.60-1.81$ & $3.40-2.61$ & $4.20-3.41$ & $5.0-4.21$ \\
\hline
\end{tabular}

خامسأ: الأساليب الإحصائية للإراسة:

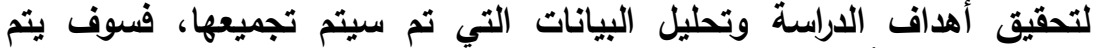

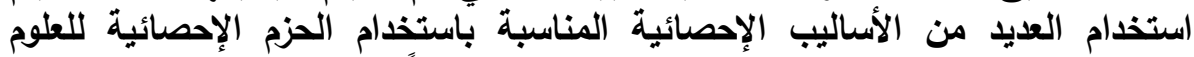

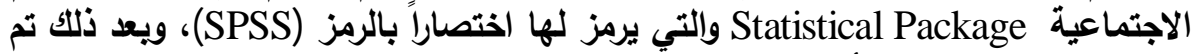

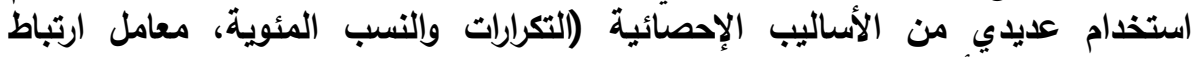

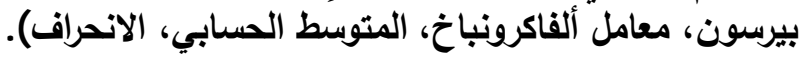
عرض نتائج الاراسة ومناقثتنها: أولاً: مناقشة وتحليل نتائج السؤال الأول: مـا واقع تمويـل الجامعات الأهليـة في المملكة العربية السعودية منية فئج جدول رقم (10) التكرارات والنسب المئوية والمتوسطات الحسابية والانحراف المعياري لاستجابات أفراد الدراسة حول واقع تمويل الجامعات الأهلية في المملكة العربية السعودية المافية

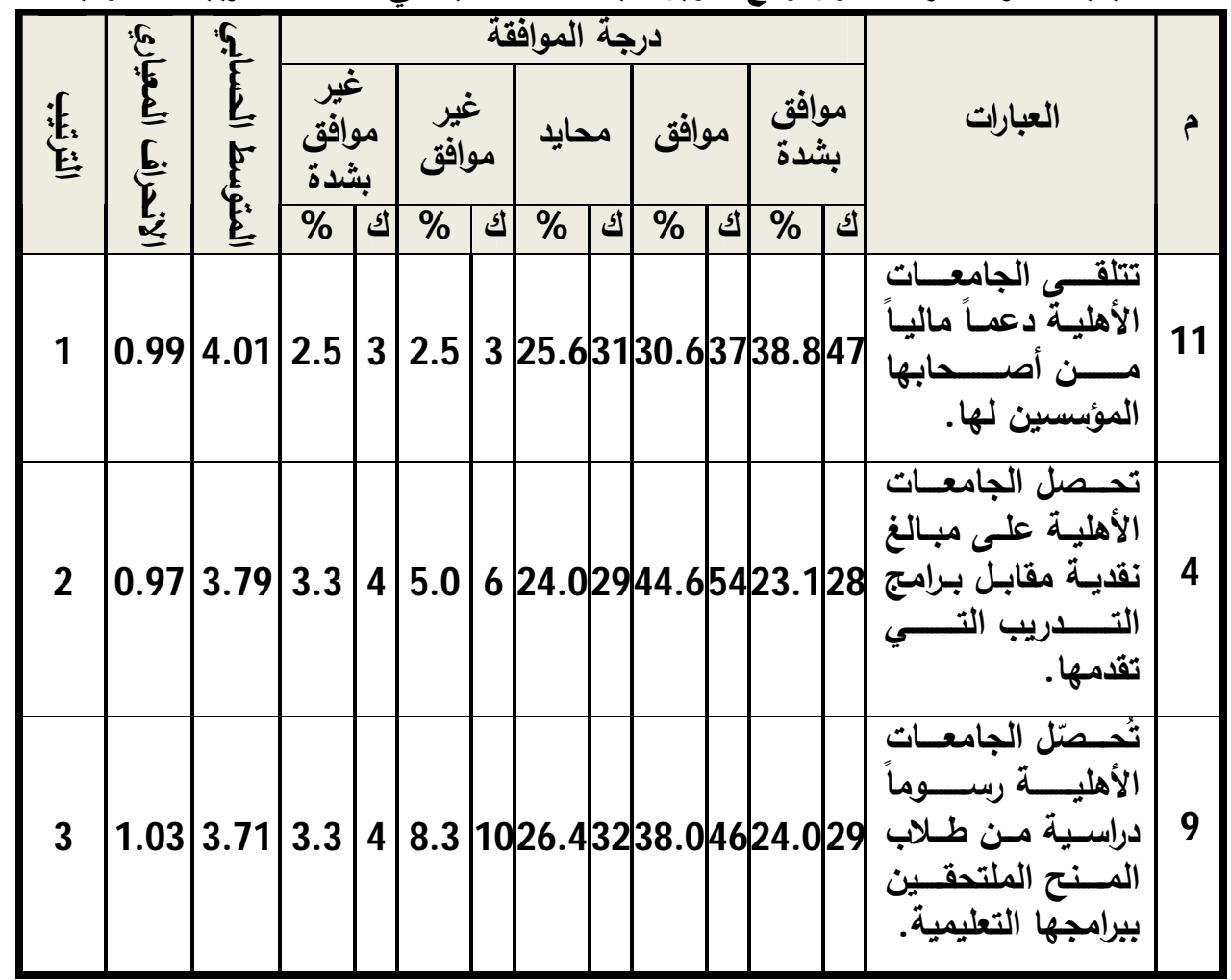


مجلة كلية التربية، جامعة الأزهر ، العدد: (183، الجزء الثاني) يوليو لسنة 2019م

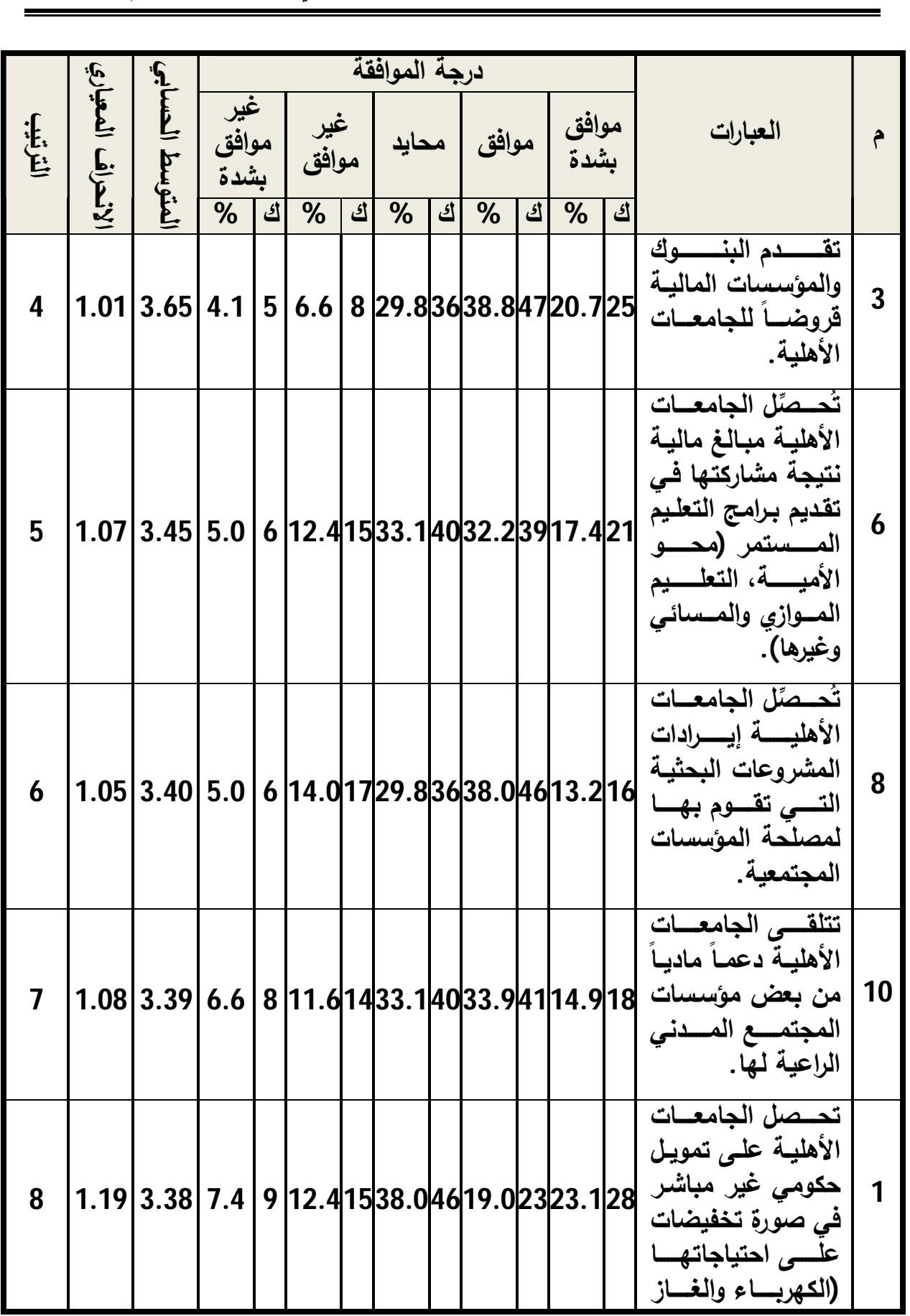

- 386- 
مجلة كلية التربية، جامعة الأزهر، العدد: (183، الجزء الثاني) يوليو لسنة 2019م

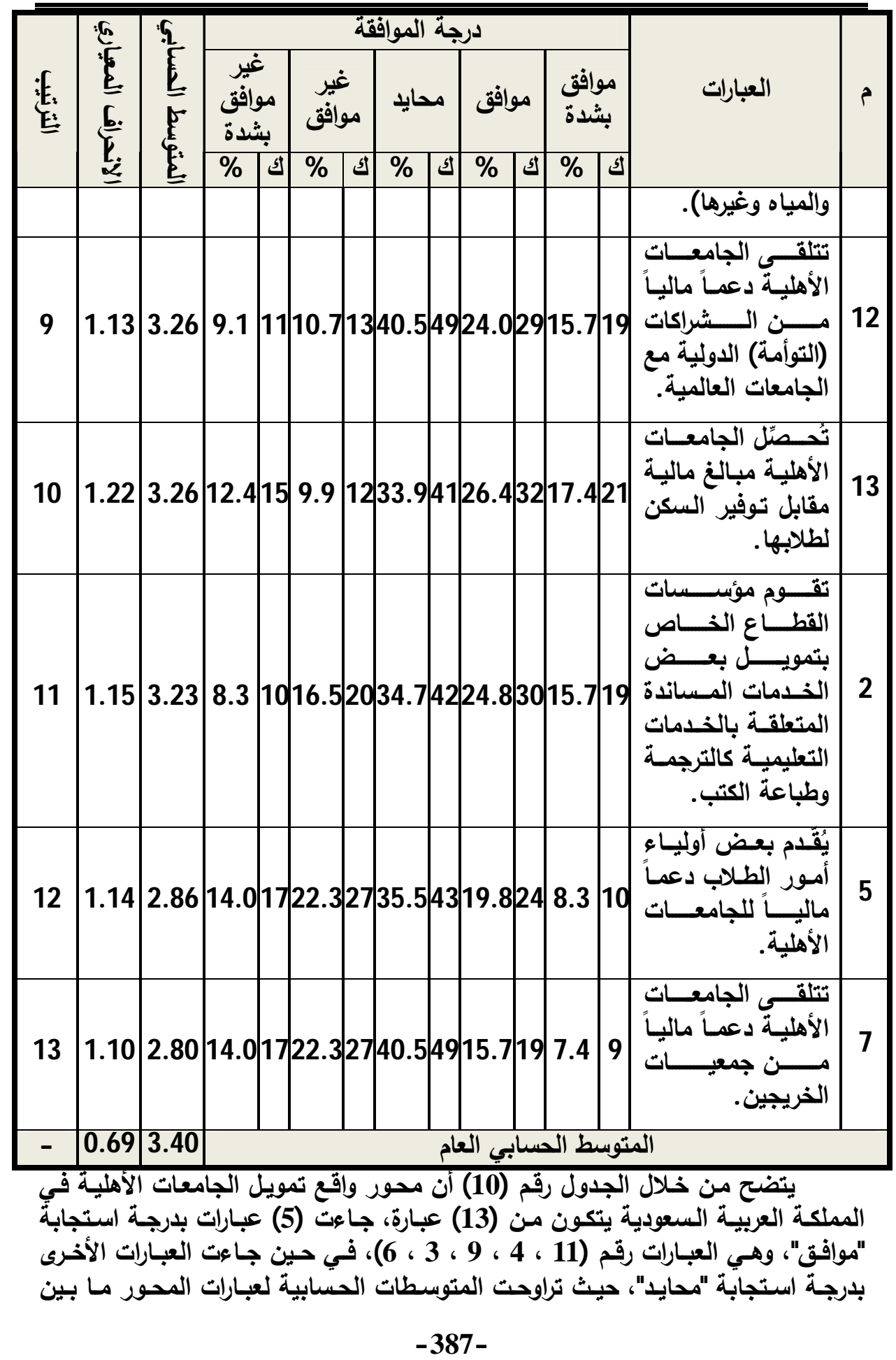




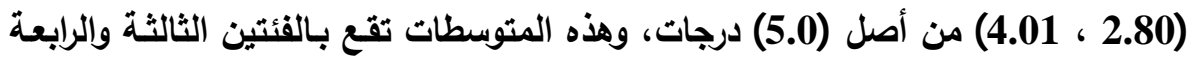

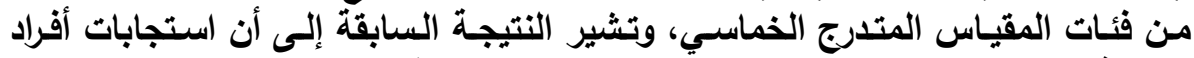

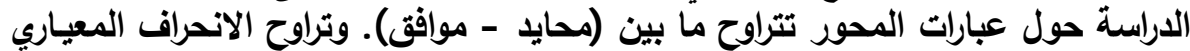

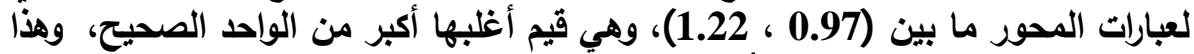

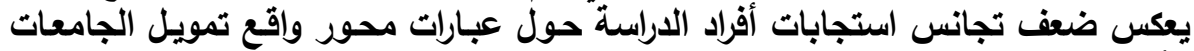

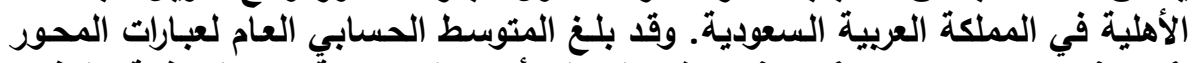

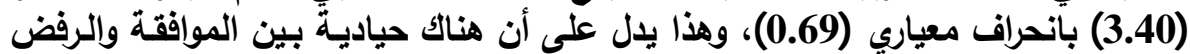

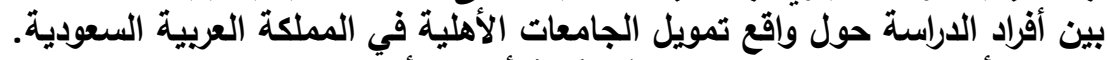

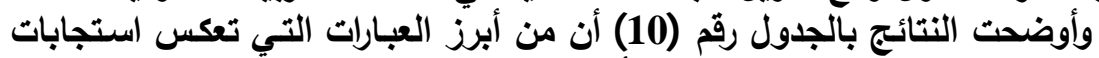

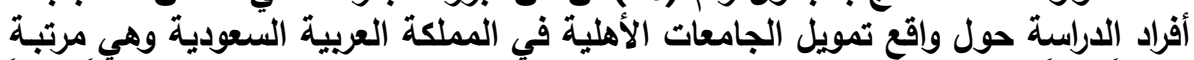

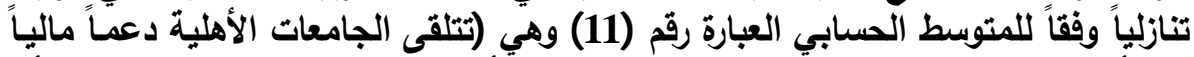

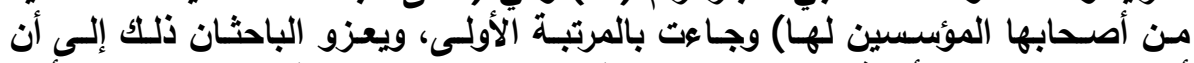

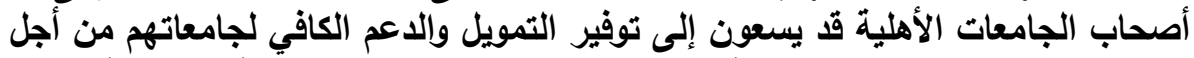

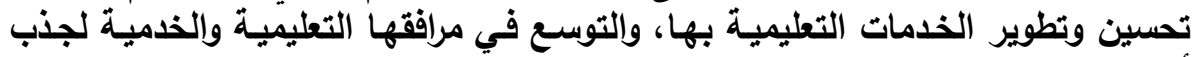

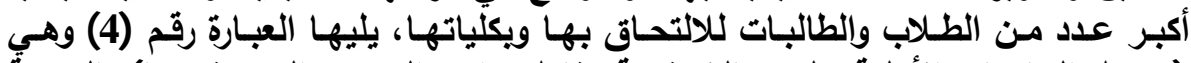

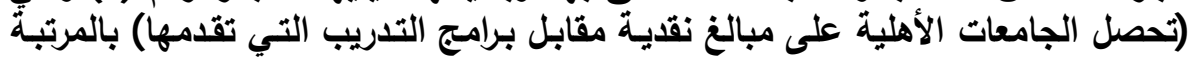

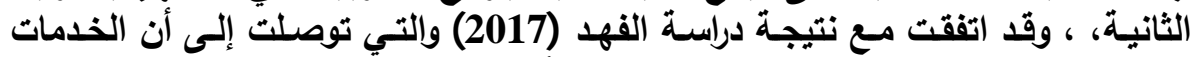

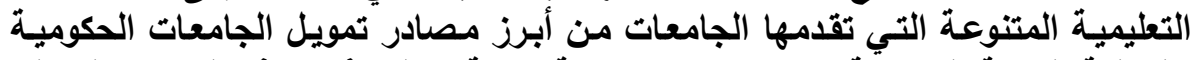

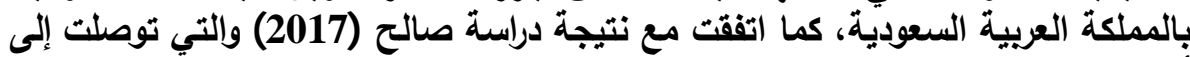

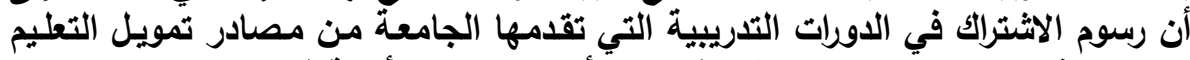

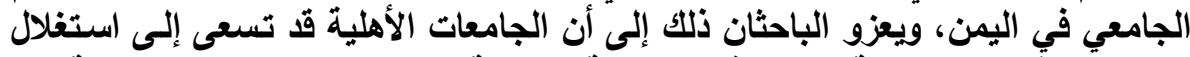

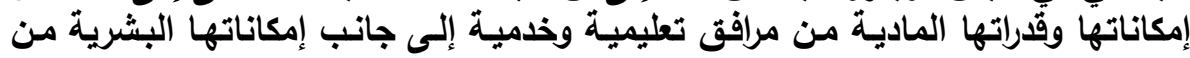

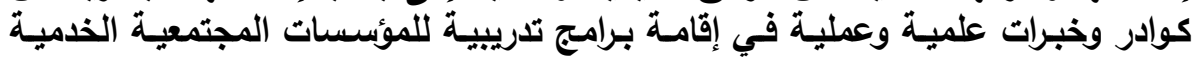

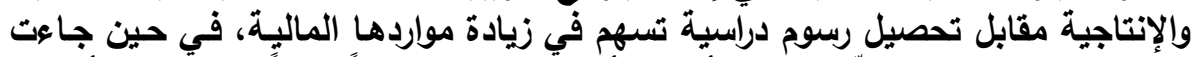

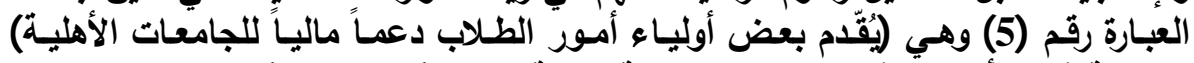

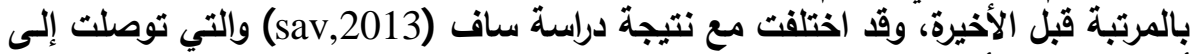

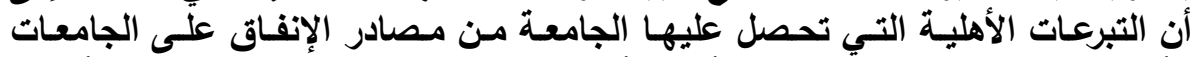

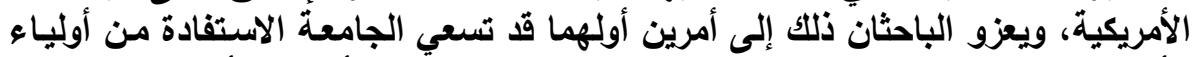

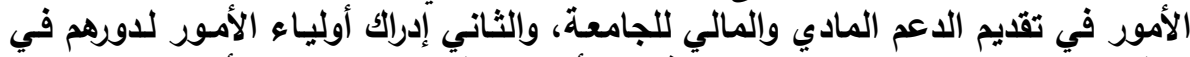

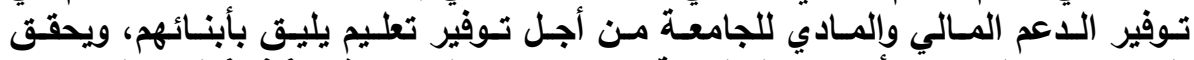

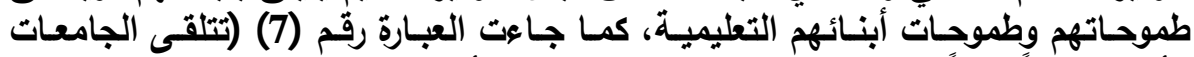

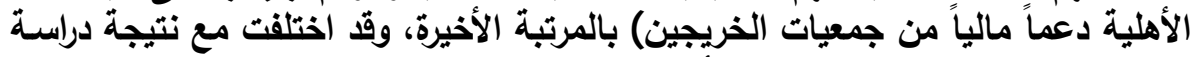

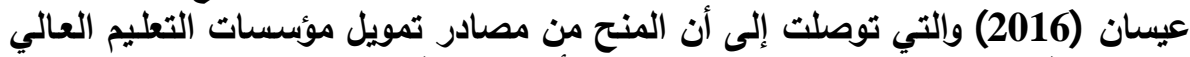

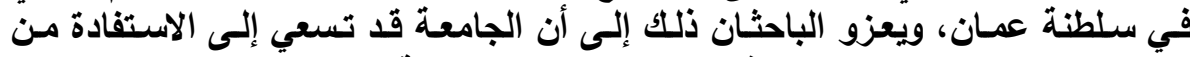

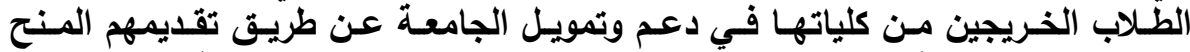

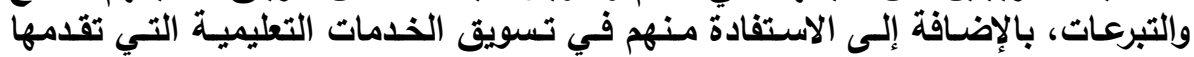


مجلة كلية التربية، جامعة الأزهر، العدد: (183، الجزء الثاني) يوليو لسنة 2019م

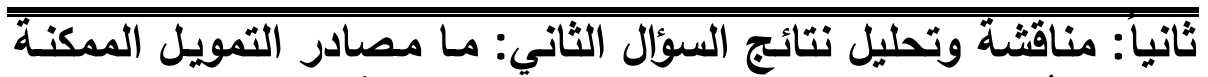

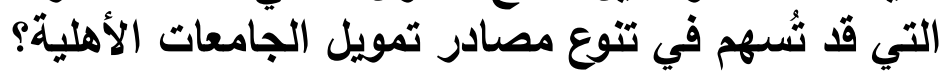

جدول رقم (11) المتوسطات الحسابية والانحراف المعياري لاستجابات أفراد الاراسة حول

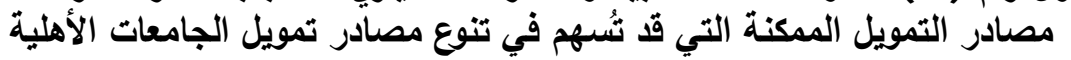

\begin{tabular}{|c|c|c|c|c|}
\hline الترتيب & 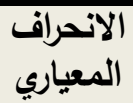 & المسابي & مصادر التمويل & م \\
\hline 1 & 0.76 & 3.63 & 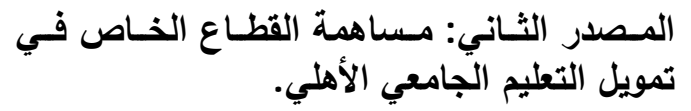 & 2 \\
\hline 2 & 0.78 & 3.62 & تمويل التعليم الجامعي الأهلي. الجامعـة المنتجـة فـي & 3 \\
\hline 3 & 0.68 & 3.58 & 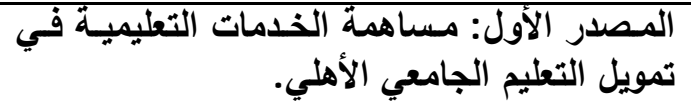 & 1 \\
\hline 4 & 0.88 & 3.55 & تمويل التعليم الجابع: مساهمي الأهلي. الوقف والمساعدات في & 4 \\
\hline - & 0.67 & 3.59 & المتوسط الحسابي العام & \\
\hline
\end{tabular}

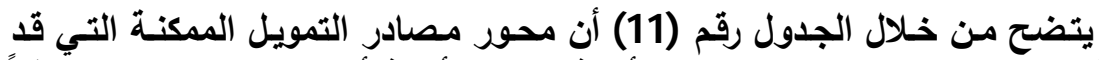

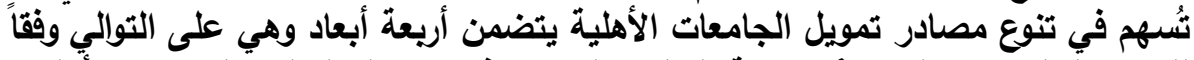

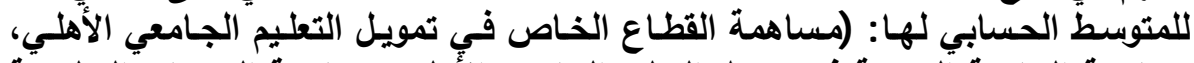

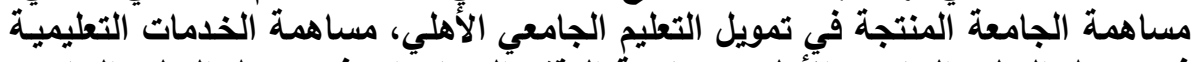

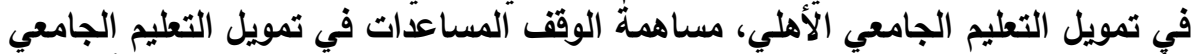

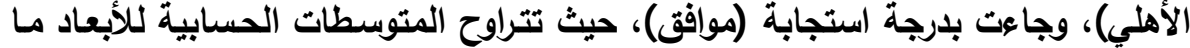

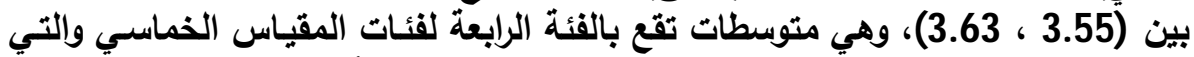

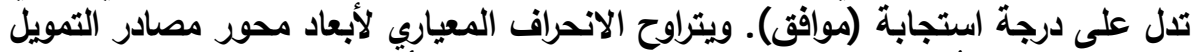

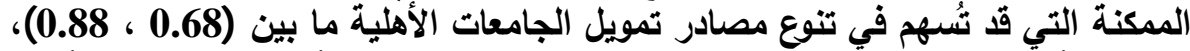

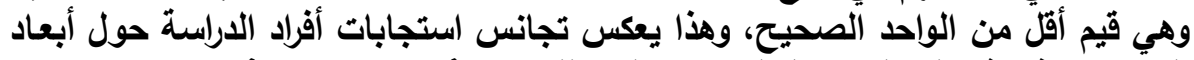

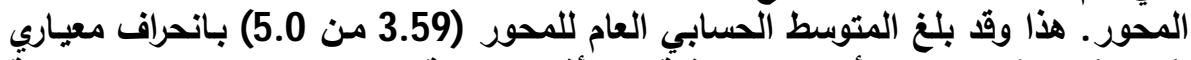

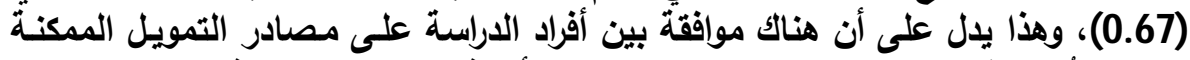

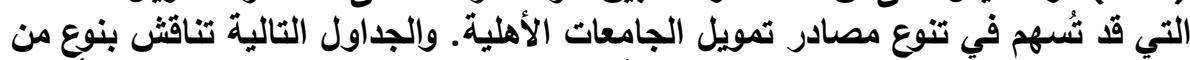

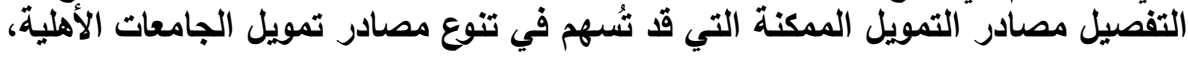

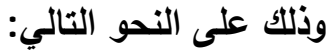


1. المصدر الأول: مساهمة الخدمات التعليميـة في تمويل التعليم الجـامعي الأهلي

جادول رقم (12) التكرارات والنسب المئوية والمتوسطات الحسابية والانحراف المعياري لاستجابات أفراد الاراسة حول مساهمة الذذمات التعليمية في تمويل التعليم الجامعي الأهلي

\begin{tabular}{|c|c|c|c|c|c|c|c|c|c|}
\hline & 5 & 5 & & & جية الموافقة & & & & \\
\hline 业 & $\underline{\underline{E}}$ & $\underline{E}$ & شدة موافق & مهافير |غ & 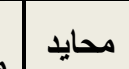 & 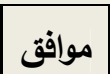 & موافق & العبارات & P \\
\hline & $\bar{E}$ & $\xi$ & $\%$ & s] $\%$ s & s| $\%$ & \begin{tabular}{|l|l|l|l|}
$\%$ & $s$ \\
\end{tabular} & $\%$ |s & & \\
\hline 1 & 1.01 & 3.79 & 2.5 & $\begin{array}{l}3 \\
\end{array} 9.9 \mid 12$ & & & 24.830 & 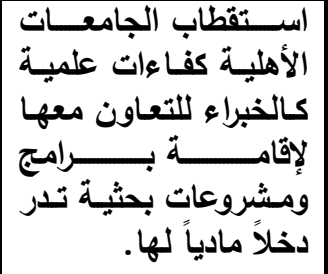 & 5 \\
\hline 2 & 1.01 & 3.75 & 2.5 & $\begin{array}{l}3.8 .3 \mid \\
0\end{array}$ & & & 5.631 & 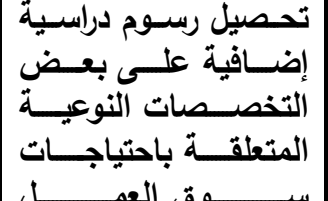 & 2 \\
\hline & & & & & & & & والتخصــــات التقنيـة & \\
\hline & & & & & & & & 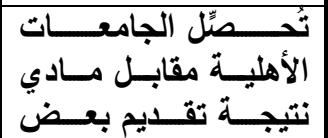 & 1 \\
\hline 3 & 1.02 & 3.71 & 1.7 & & & & & 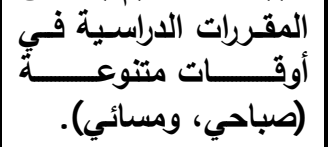 & 1 \\
\hline 4 & 0.96 & 3.70 & 1.7 & & & & 21.526 & الإيراديت تعقدهات البرامج الجامعايبية & 6 \\
\hline & & & & & & & & المؤسسات المجتمعية." & \\
\hline $\mathbf{5}$ & 1.03 & 3.69 & 5.0 & $6 \mid 5.0$ & & & & 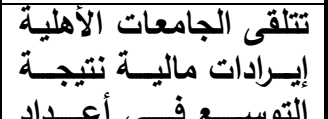 & 3 \\
\hline & & & & & & & & المقبـــولَين بيرِنـــامجي & \\
\hline
\end{tabular}


مجلة كلية التربية، جامعة الأزهر، العدد: (183، الجزء الثاني) يوليو لسنة 2019م

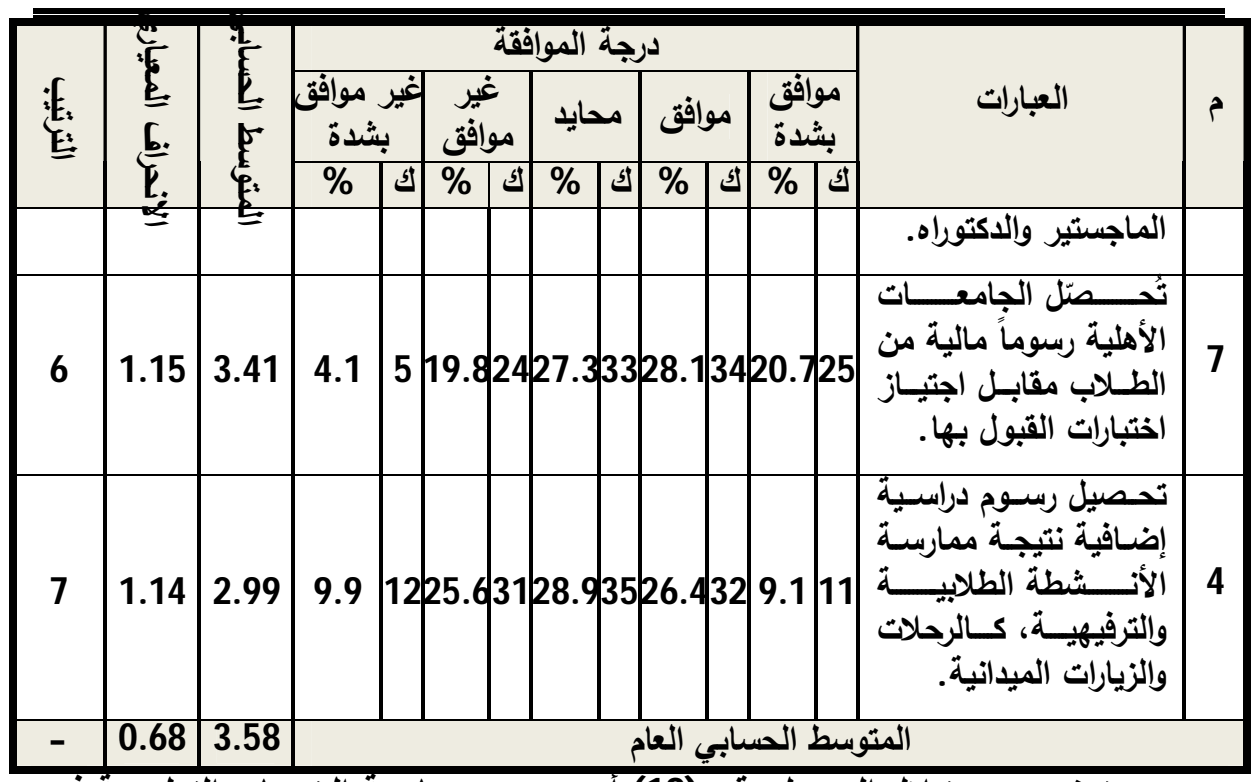

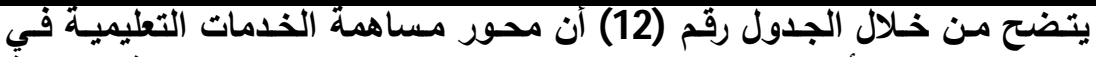

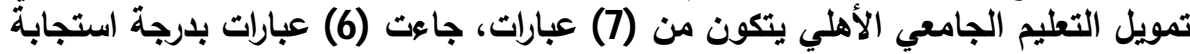

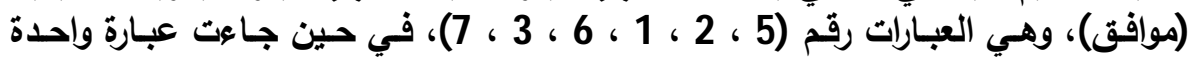

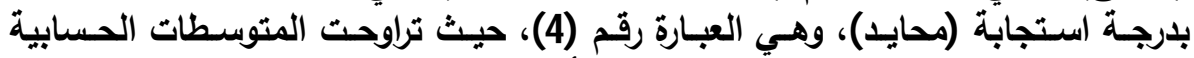

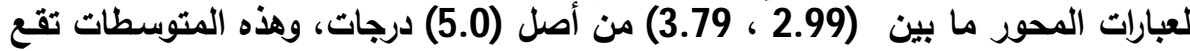

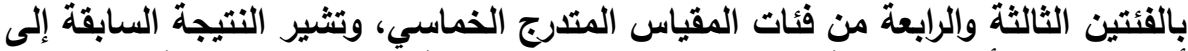

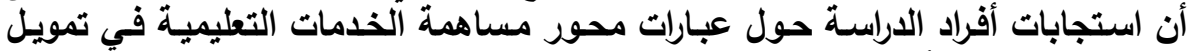

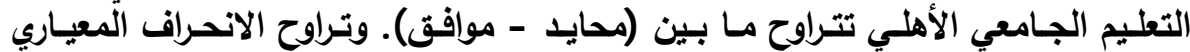

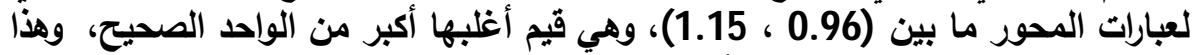

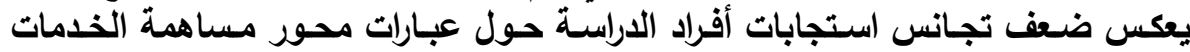

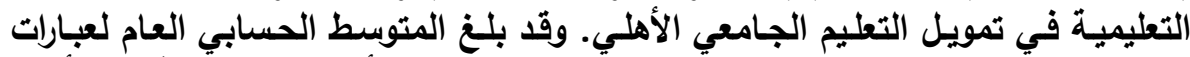

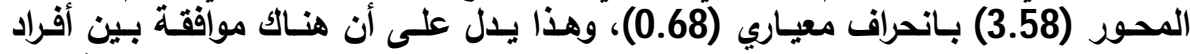

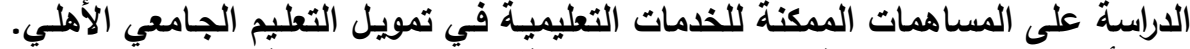

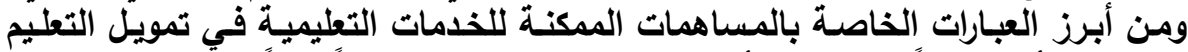

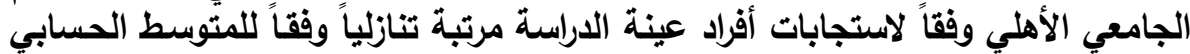

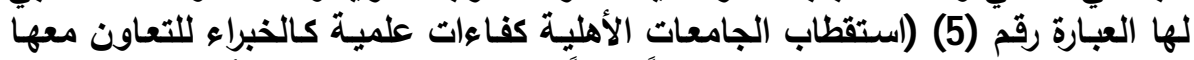

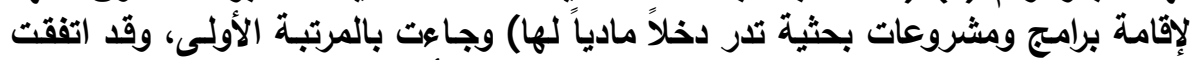

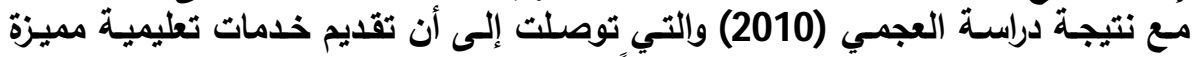
للطلاب مقابل دفع رسوم مالية عالية نسبياً من مصادر التمويل المقترحة للتعليم الجامعي

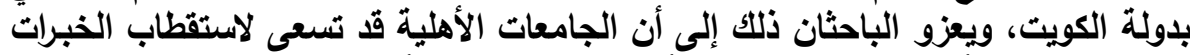

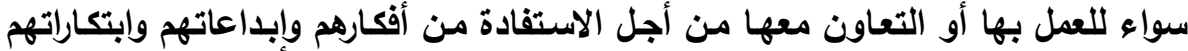

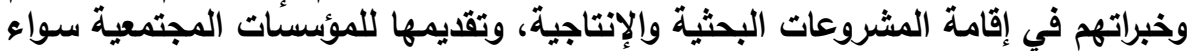


الخدمية أو الإنتاجية مقابل مبالغ مالية، وذلك في إطار سعي إدارة الجامعة أو أصحابها

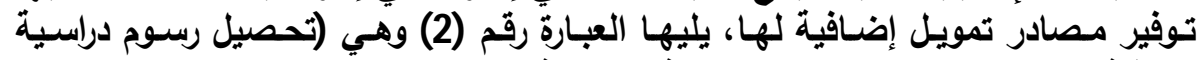

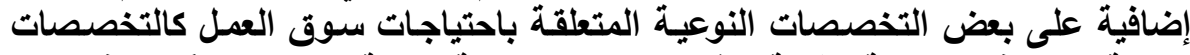

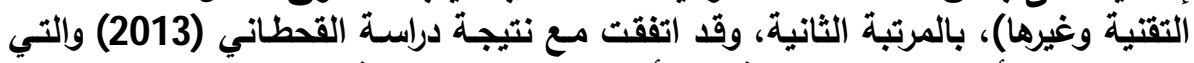

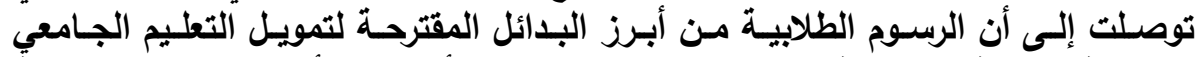

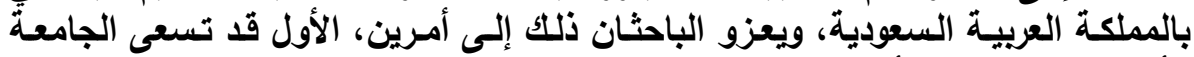

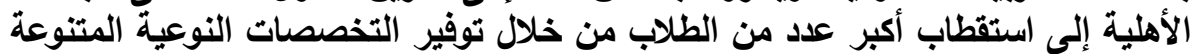

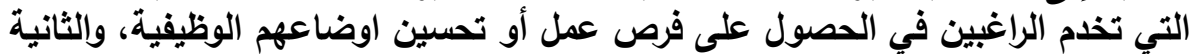

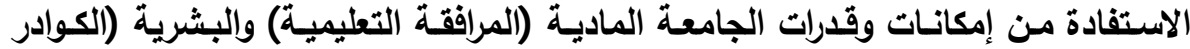

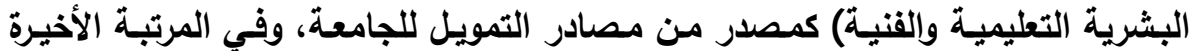

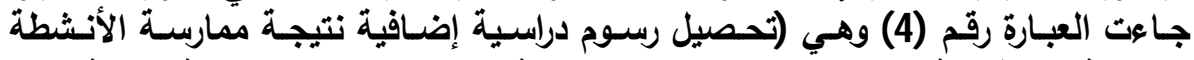

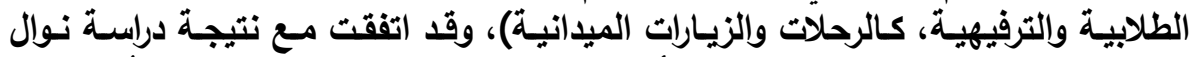

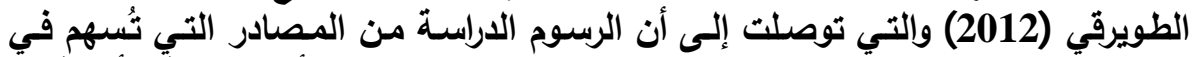

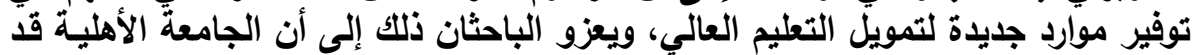

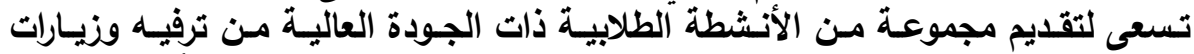

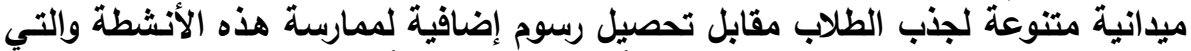
قد يتم تحويل جزء منها للتوسع في هذه الأنشطة لاستيعاب أكبر عدابد من الطلاب الراغبين في الالتحاق بالجامعة. 2. المـصدر الثـاني: مسـاهمة القطـاع الخـاص في تمويـل التعليم الجـامعي الأهلي

جدول رقم (13) التكرارات والنسب المئوية والمتوسطات الحسابية والانحراف المعياري لاستجابات أفراد الدراسة حول مساهمة القطاع الناع الخاص في تمويل التعليم الجامعي الأهلي

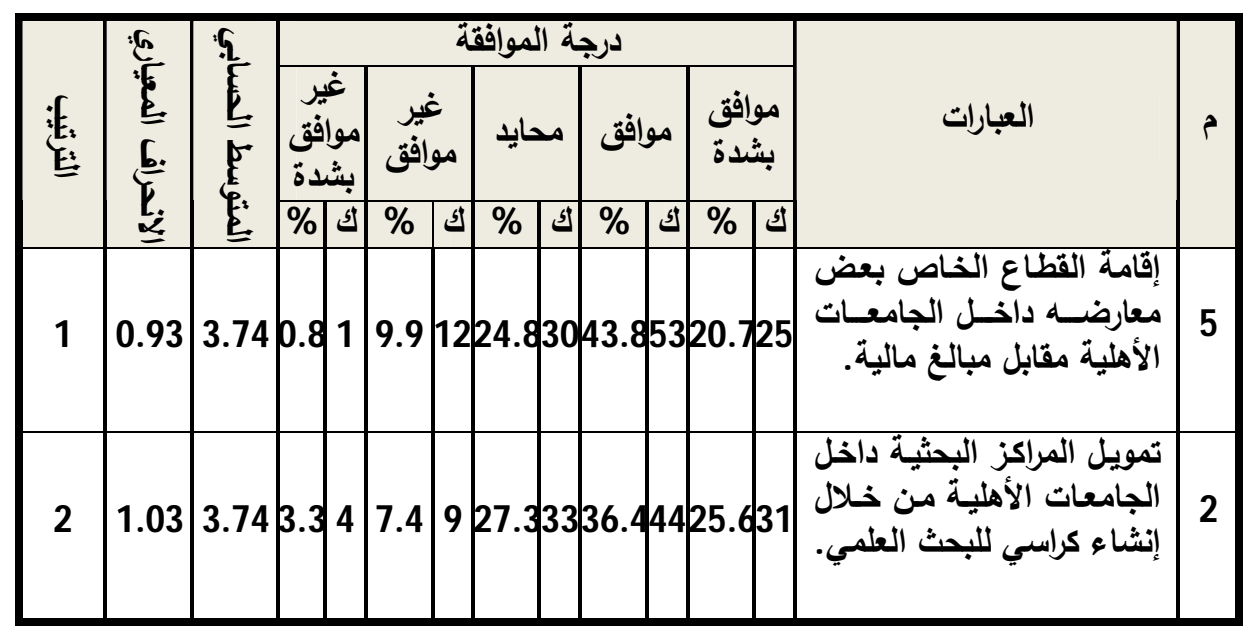


مجلة كلية التربية، جامعة الأزهر، العدد: (183، الجزء الثاني) يوليو لسنة 2019م

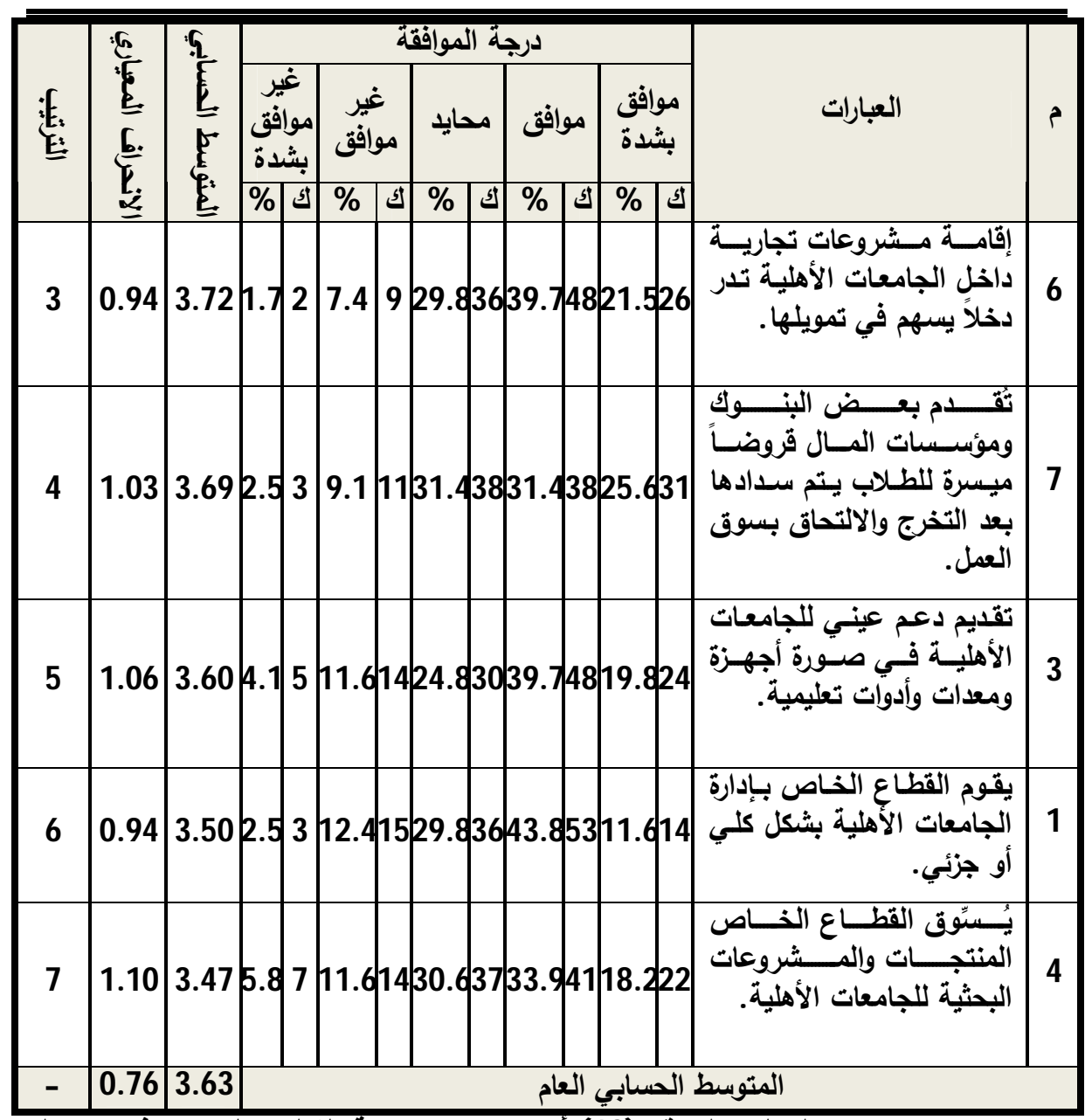

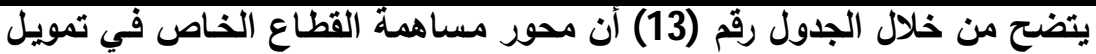

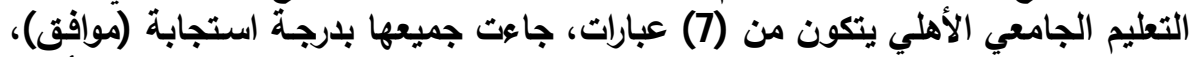

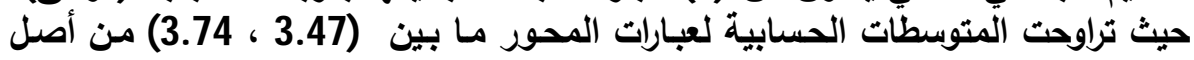

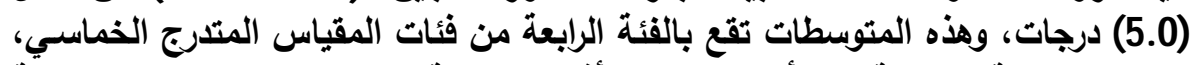

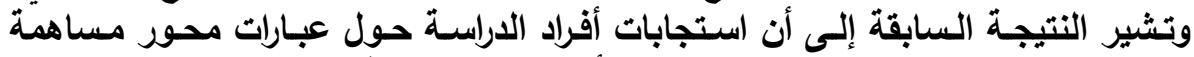

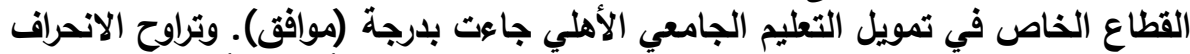

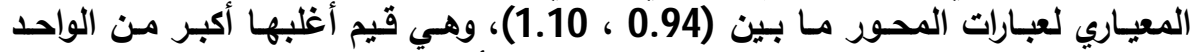

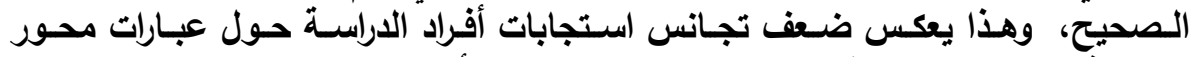

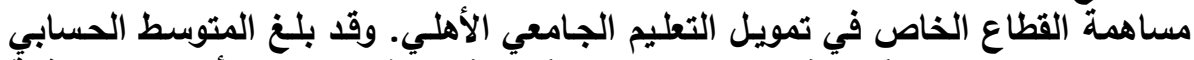

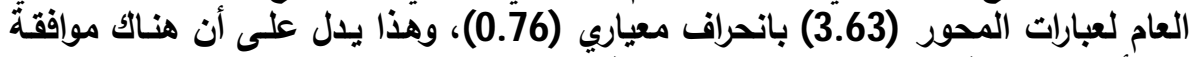

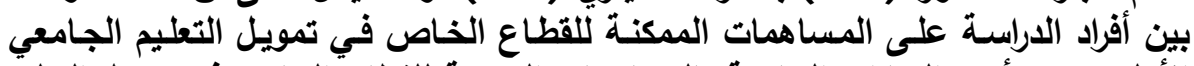

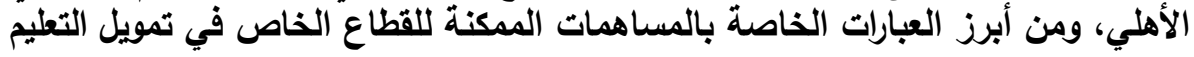




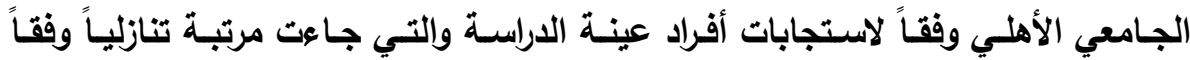

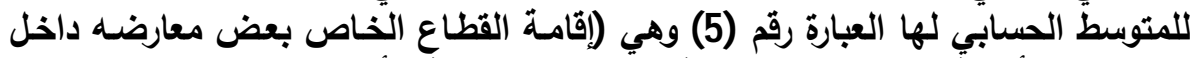

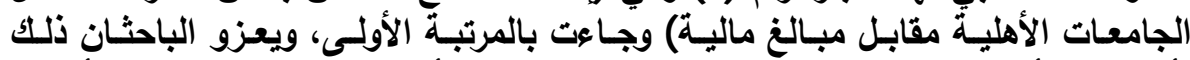

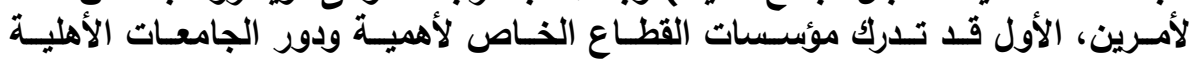

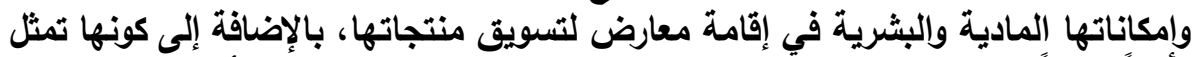

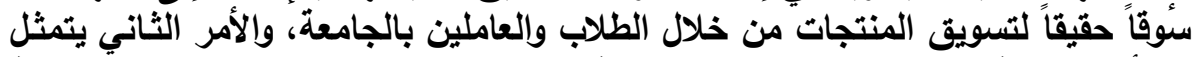

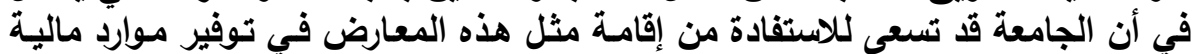

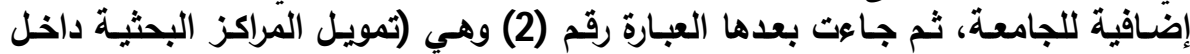

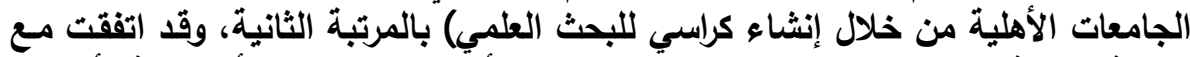

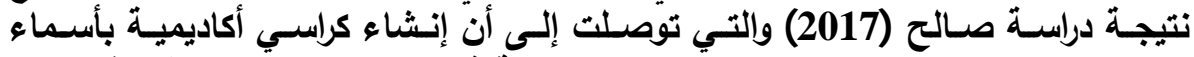

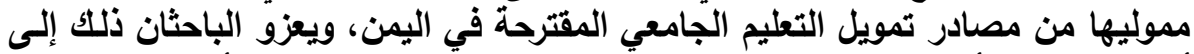

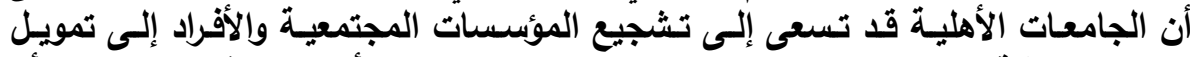

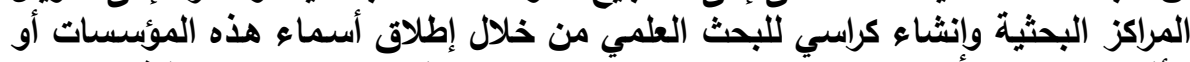

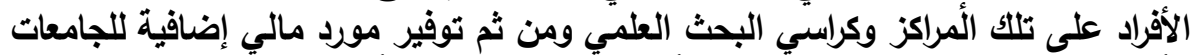

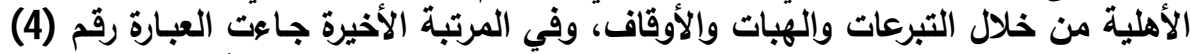

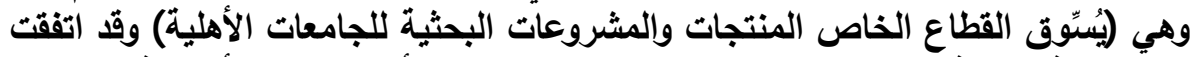

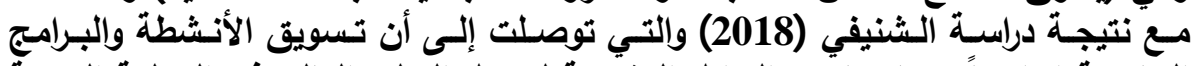

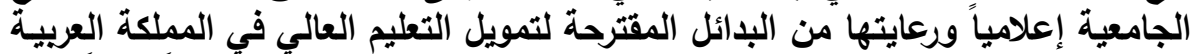

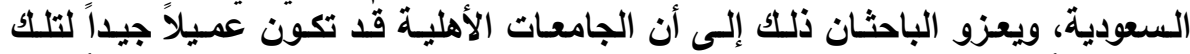

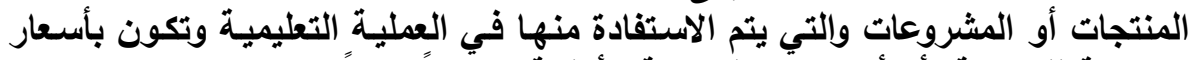

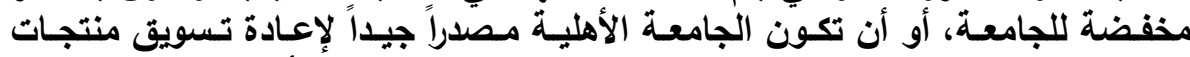

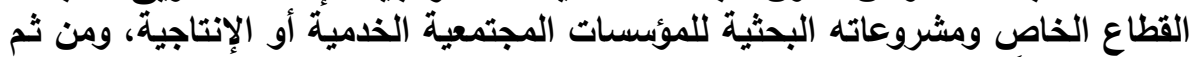
تحقيق أرياحاً مالية من وراء هذاء التهائ التسويق.

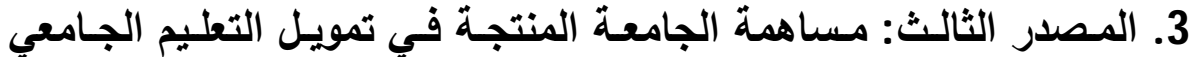

جدول رقم (14) التكرارات والنسب المئوية والمتوسطات الحسابية والانحراف المعياري لاستجابات أفراد الدراسة حول مساهمة الجامعة المنتجة في تمويل التعليم الجامعي الأهلي

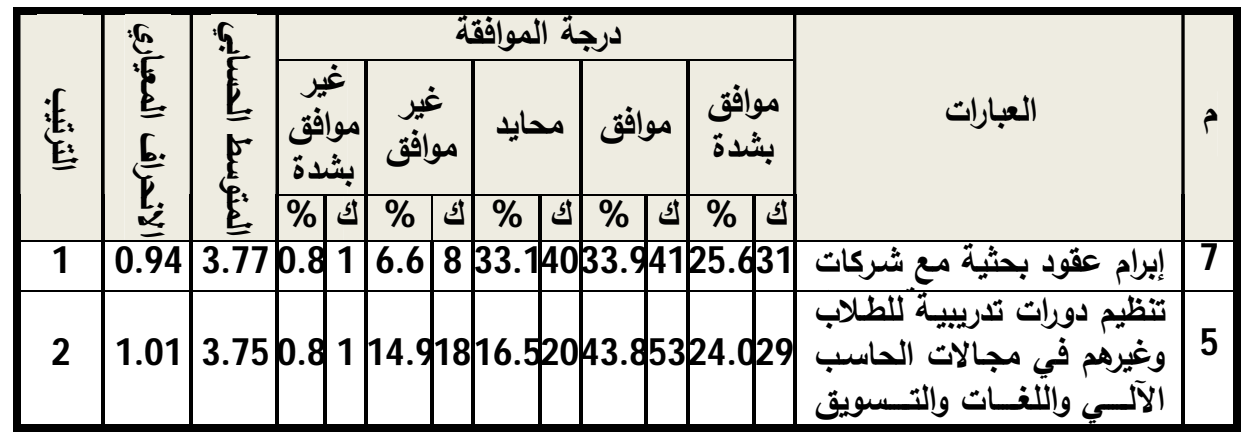


مجلة كلية التربية، جامعة الأزهر، العدد: (183، الجزء الثاني) يوليو لسنة 2019م

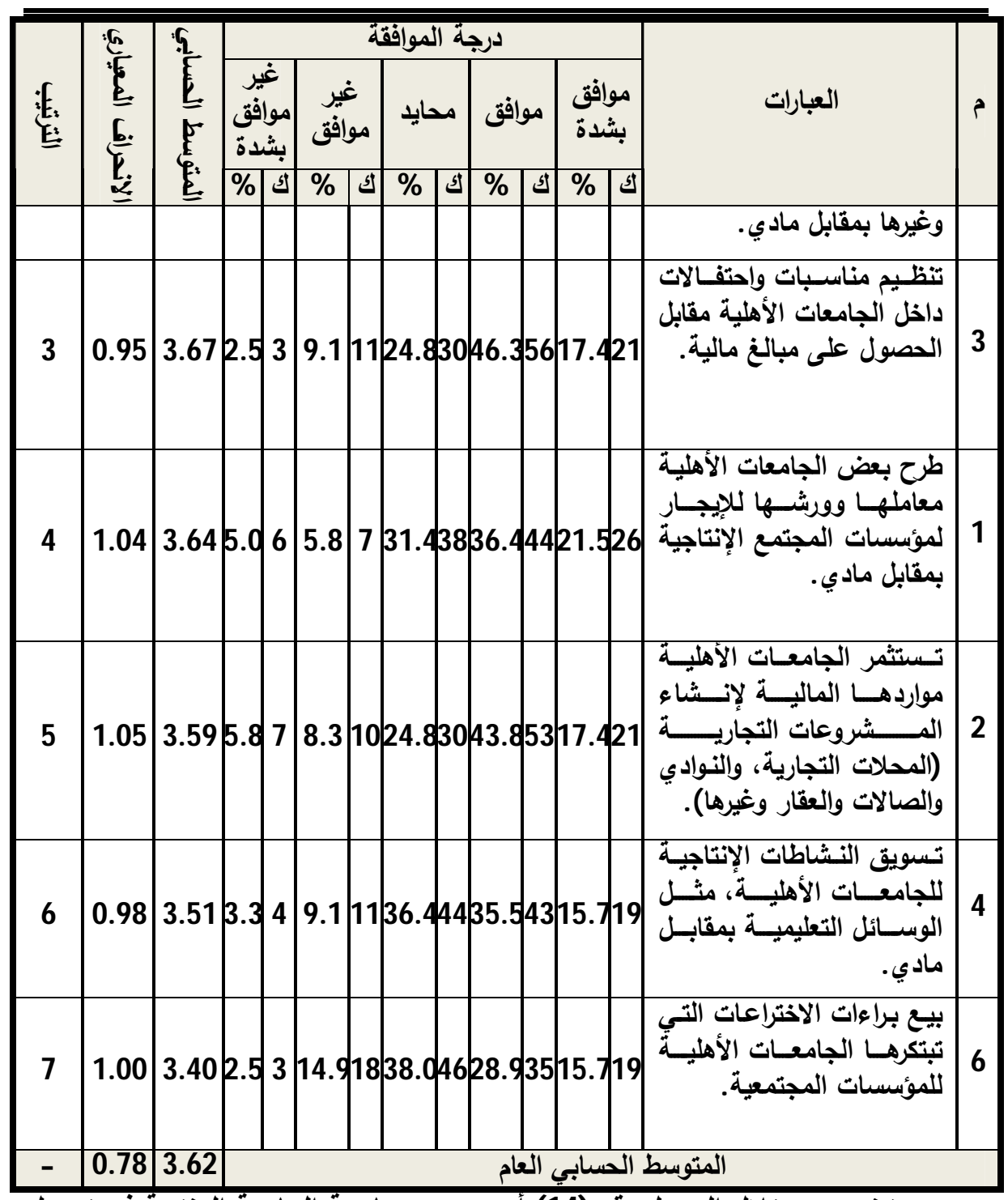

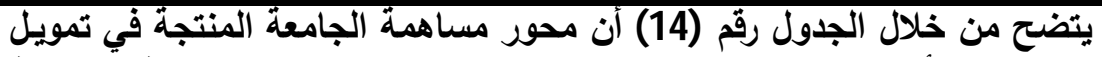

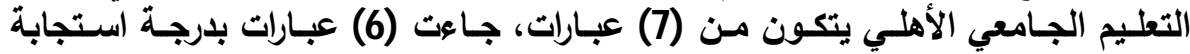

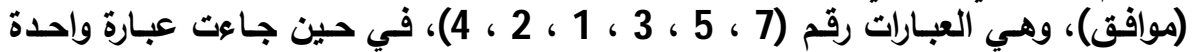

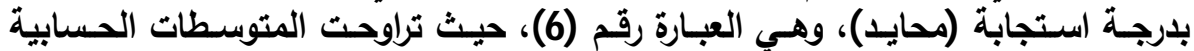

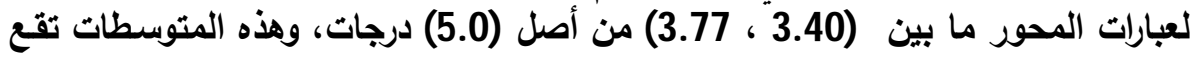

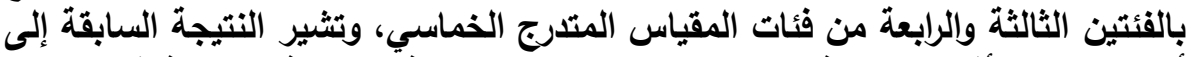

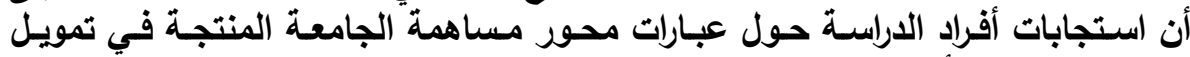
التعليم الجامعي الأهلي تتراوح ما بين (محايد -موافق) ـ تراوح الانحراف المعياري لعبارات 


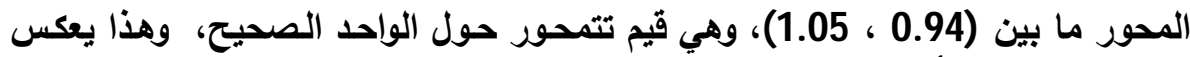

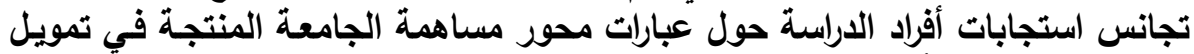

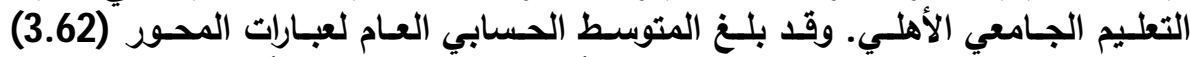

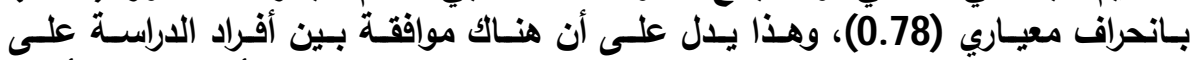

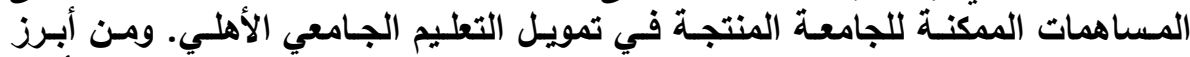

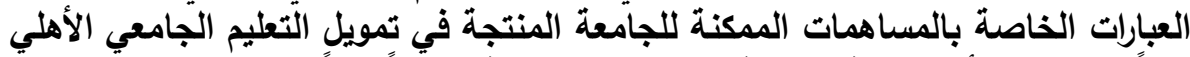

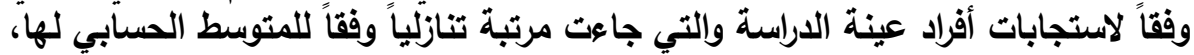

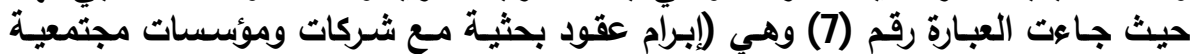

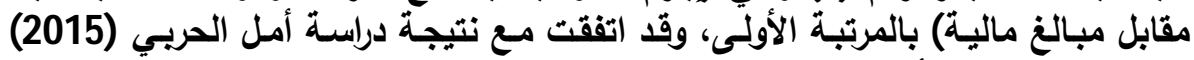

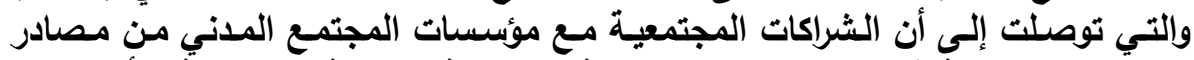

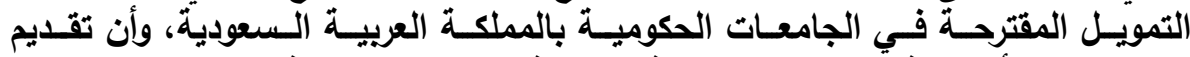

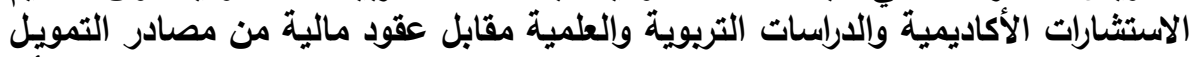

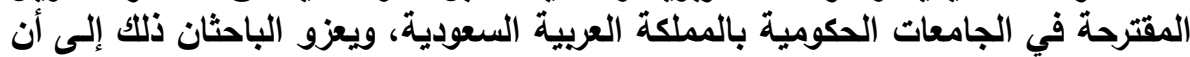

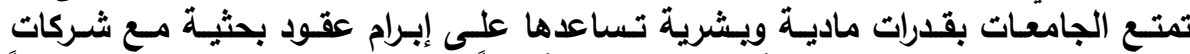

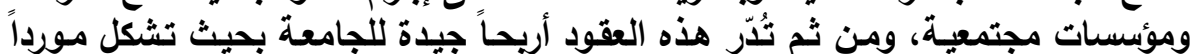

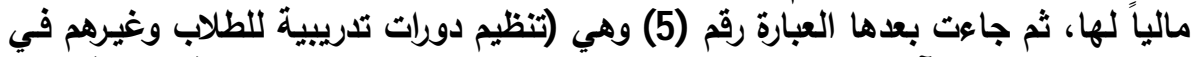

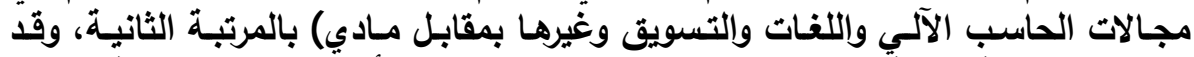

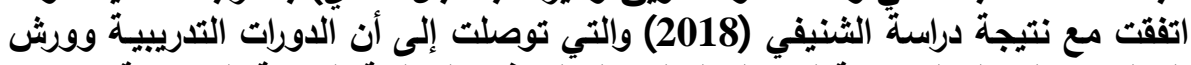

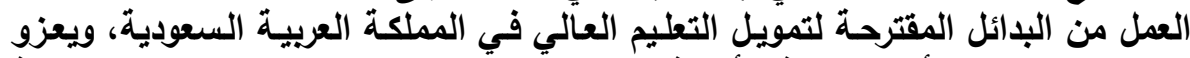

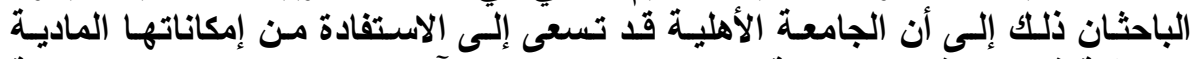

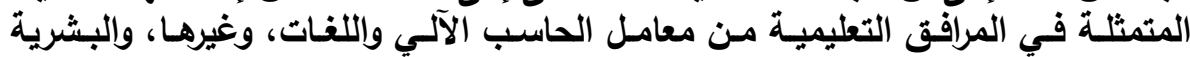

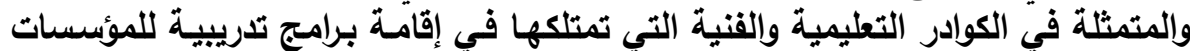

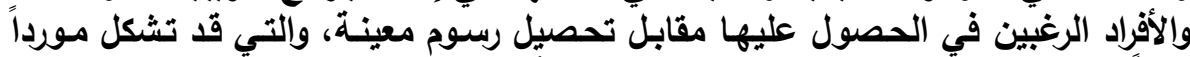

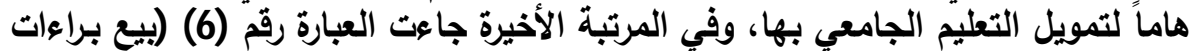

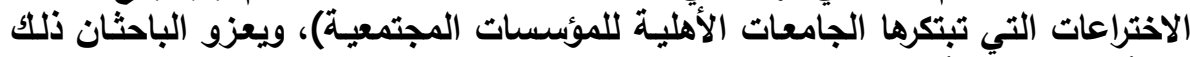

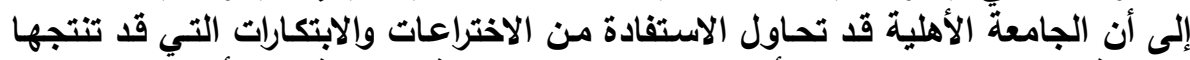

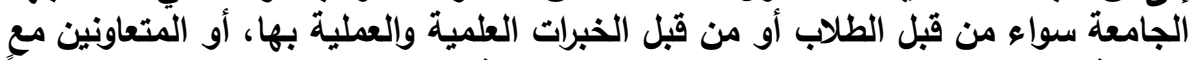

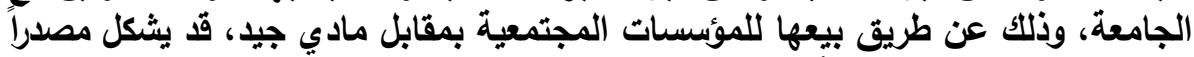
من مصادر دخل الجامعة الأُهلية. 
مجلة كلية التربية، جامعة الأزهر، العدد: (183، الجزء الثاني) يوليو لسنة 2019م

4. المصدر الرابع: مساهمة الوقف والمساعدات في تمويل التعليم الجـامعي الأهلي.

جدول رقم (15) التكرارات والنسب المئوية والمتوسطات الحسابية والانحراف المعياري لاستجابات أفراد الاراسة حول مساهمة الوقف والمساعدات في تمويل التعليم الجامعي

الأهلي

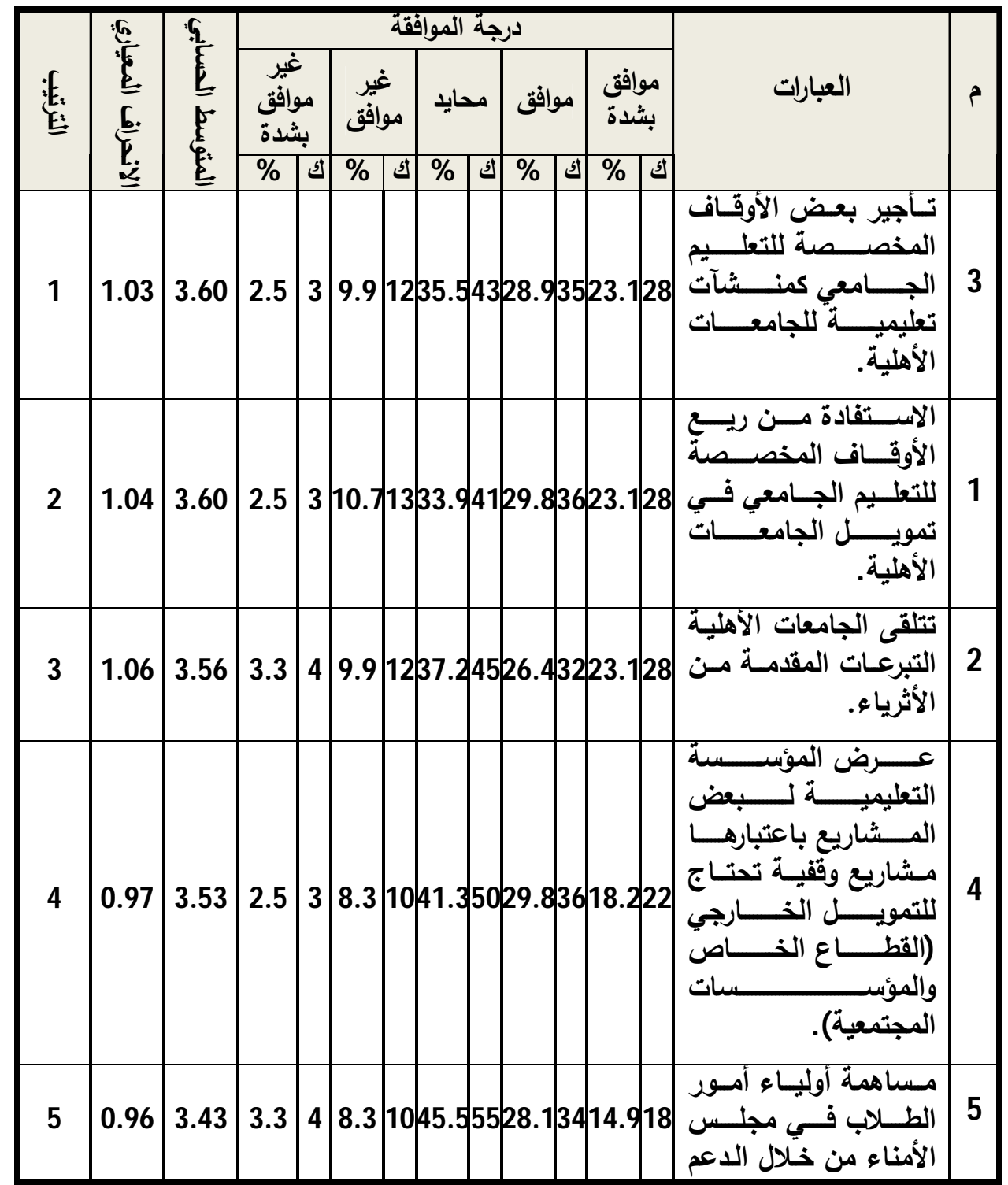

- 397- 


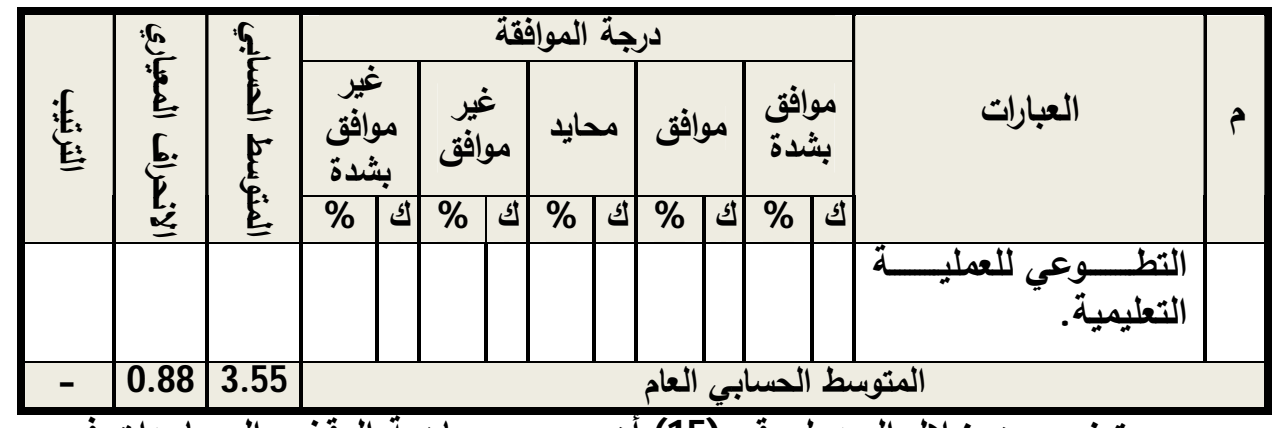

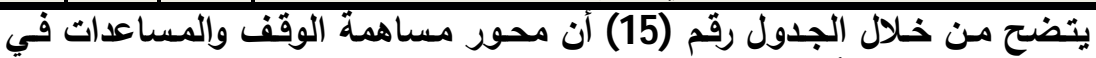

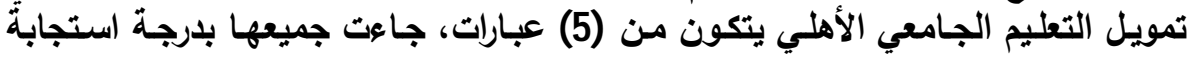

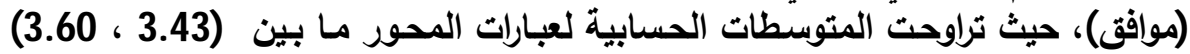

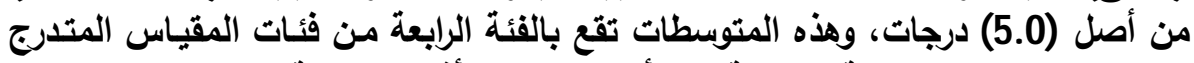

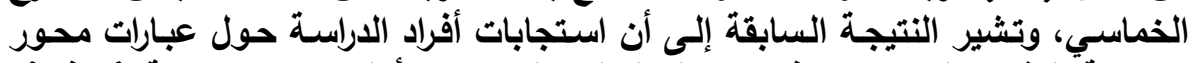

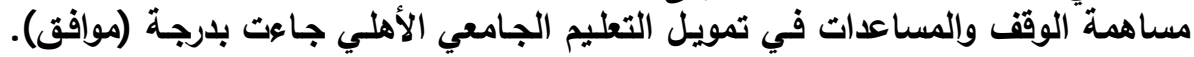

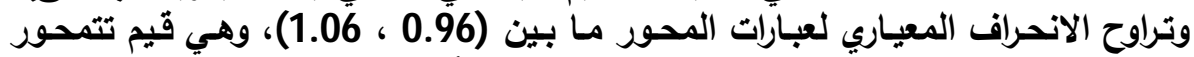

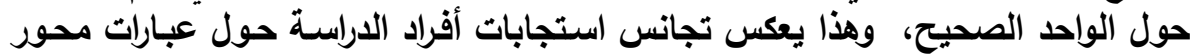

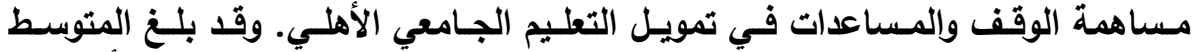

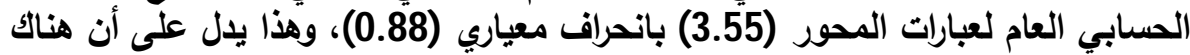

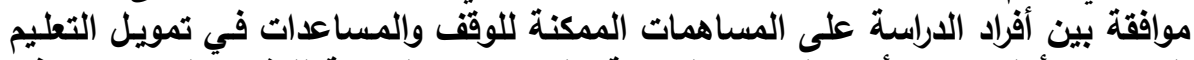

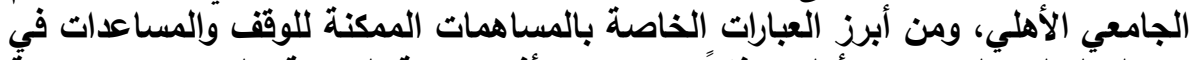

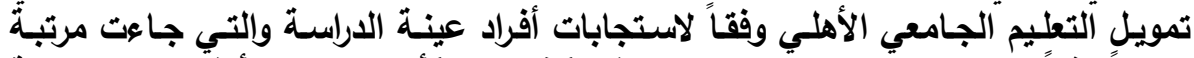

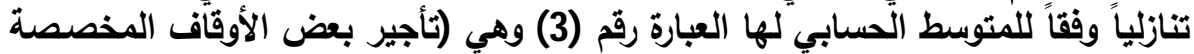

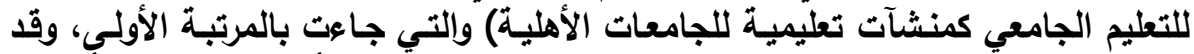

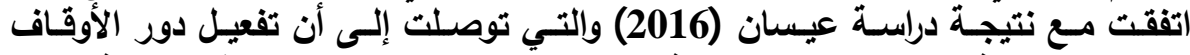

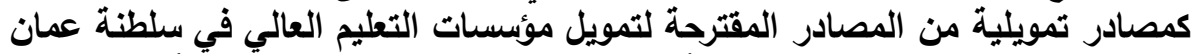

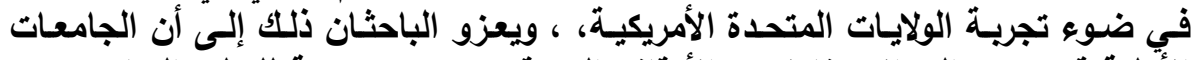

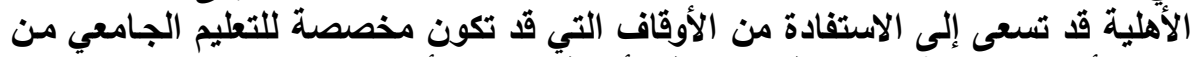

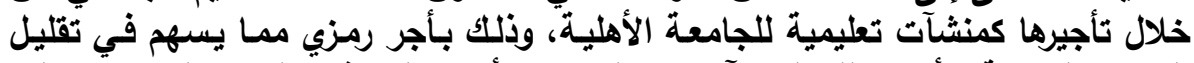

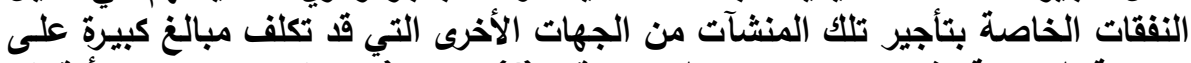

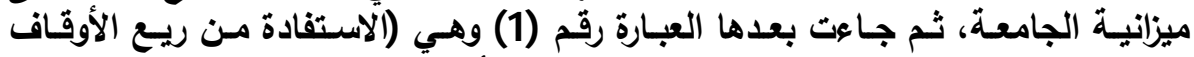

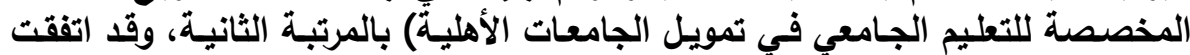

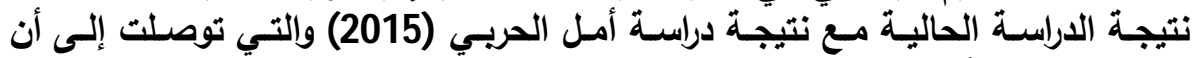

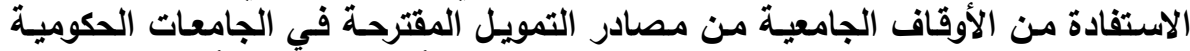

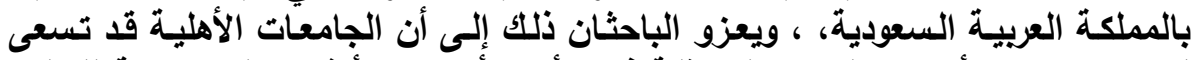

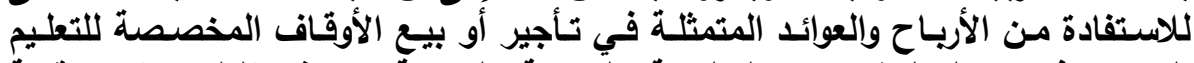

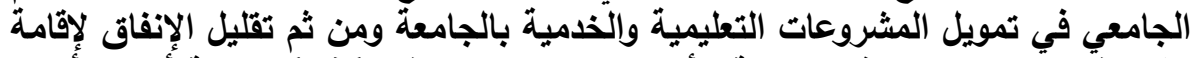

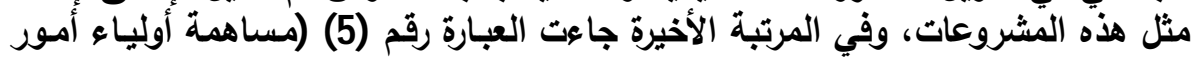


مجلة كلية التربية، جامعة الأزهر، العدد: (183، الجزء الثاني) يوليو لسنة 2019م

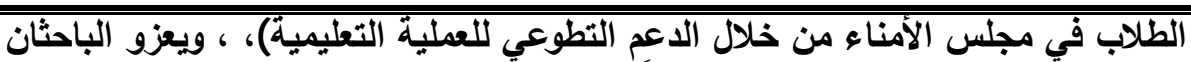

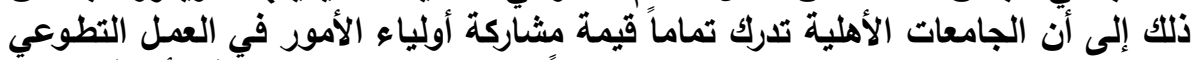

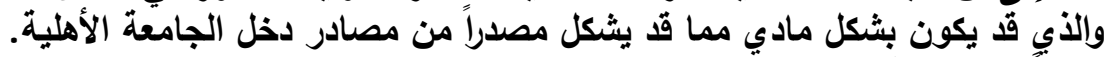

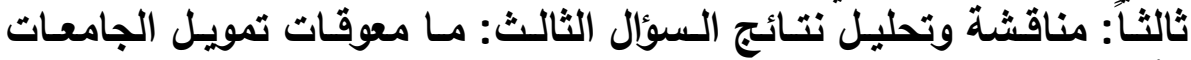
الأهلية في المملكة العربية السعودية وتئج

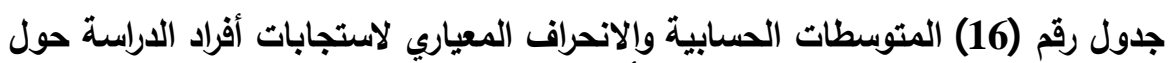
معوقات تمويل الجامعات الأهلية في المملكة العربية السعودية لابنية ألمانية

\begin{tabular}{|c|c|c|c|c|}
\hline الترتيب & المعياري & المسابي & مصادر التمويل & م \\
\hline 1 & 0.73 & 3.75 & 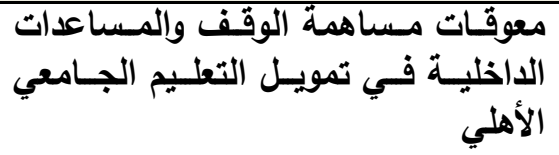 & 4 \\
\hline 2 & 0.70 & 3.70 & 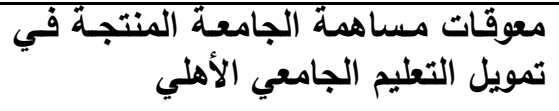 & 3 \\
\hline 3 & 0.62 & 3.62 & في تمويل التعليم الجامعي الأهلي التعليمية & 1 \\
\hline 4 & 0.76 & 3.62 & 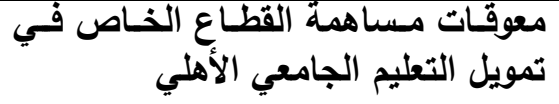 & 2 \\
\hline- & 0.62 & 3.67 & ط الحسابي العام & \\
\hline
\end{tabular}

يتضح من خلال الجدول رقم (16) أن محور معوقات تمويل الجامعات الأهلية في إني

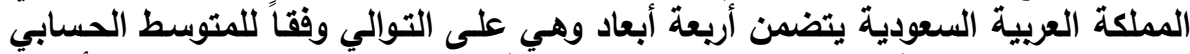

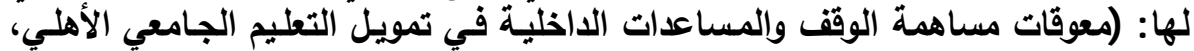

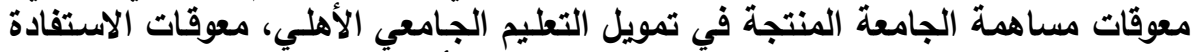

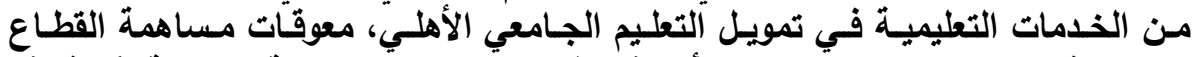

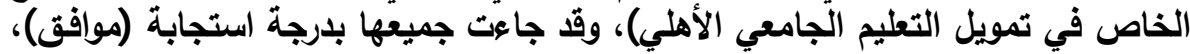

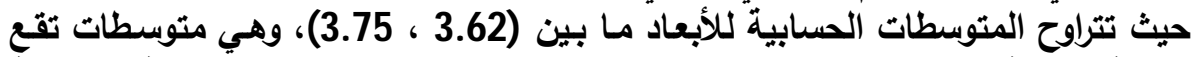

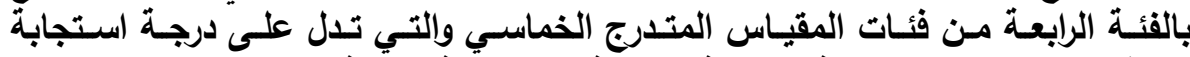

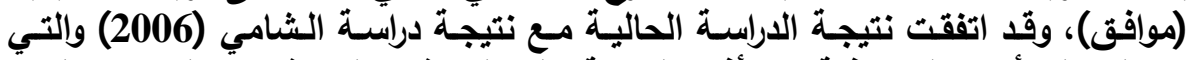

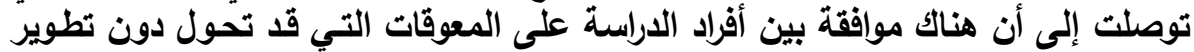

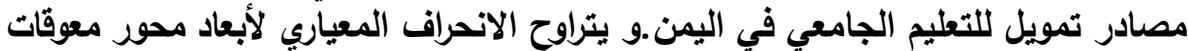

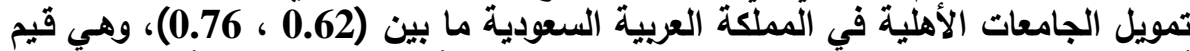

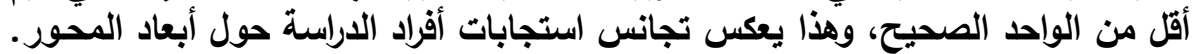

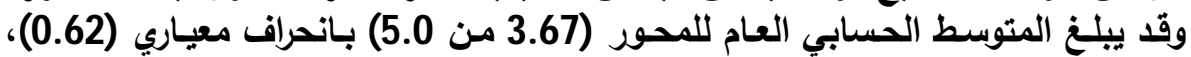

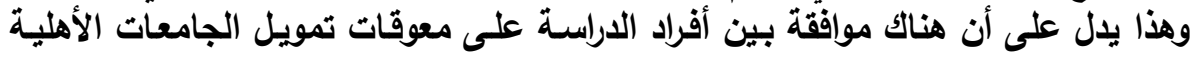


في الملكة العربية السعودية. والجداول التالية تناقش بنوع من التفصيل معوقات تمويل الجامعات الأهلية في الملكة العربية السعودية، وذلك على النحو التالي:

1. المعوقات المتعلقة بالاستفادة من الخدمات التعليمية في تمويل

$$
\text { التعليم الجامعي الأهلي. }
$$

جدابات رقم (17) التكرارات والنسب المئوية والمتوسطات الحسابية والانحراف المعياري لاستجابات أفراد الدراسة حول معوقات الاستفادة من الذذمات التعليمية في تمويل التعليم التيمي الجامعي الأهلي

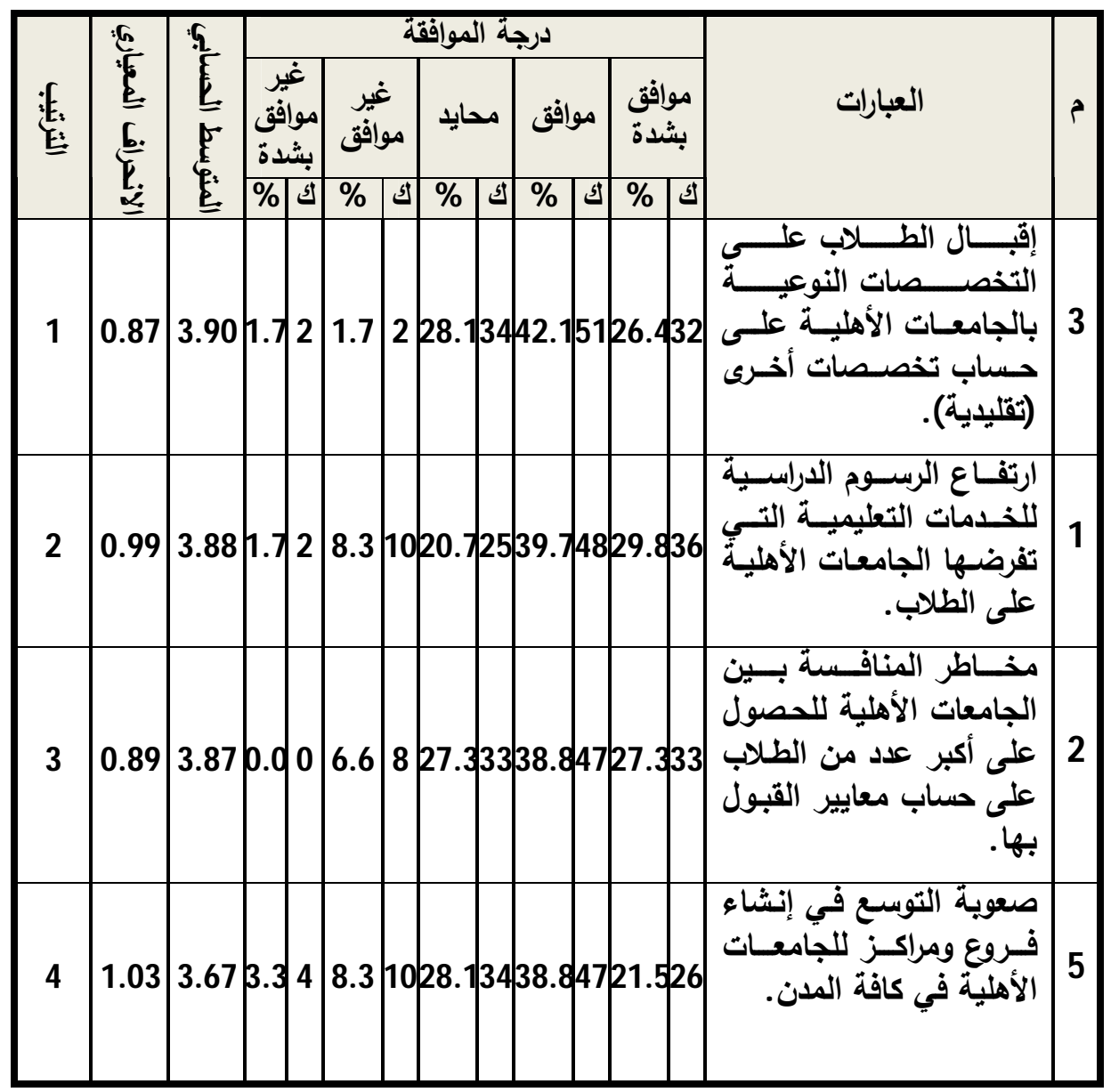


مجلة كلية التربية، جامعة الأزهر، العدد: (183، الجزع الثاني) يوليو لسنة 2019م

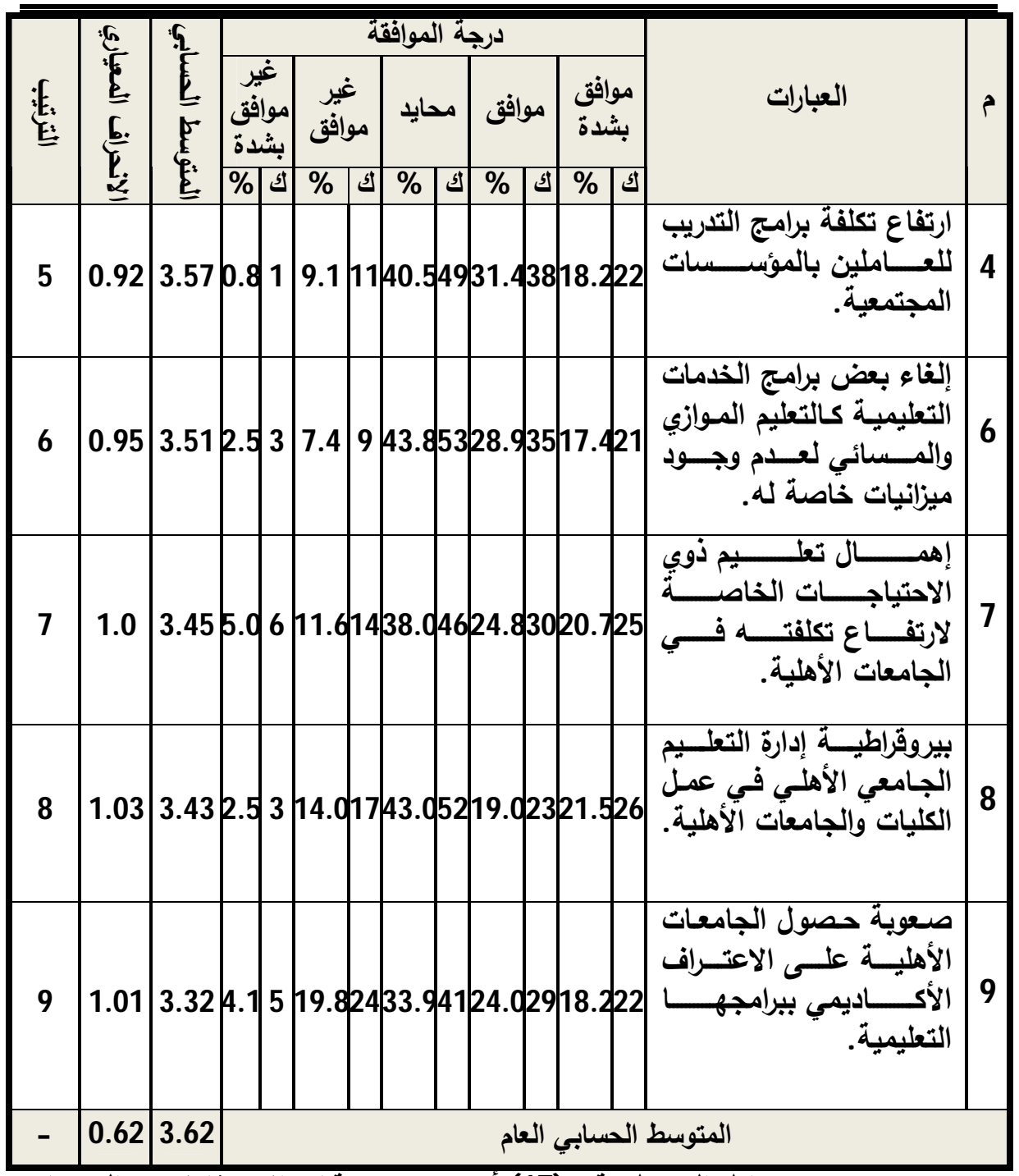

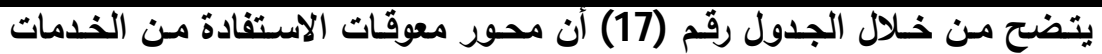

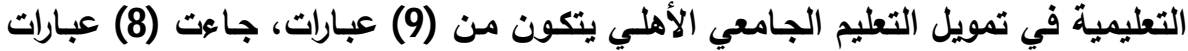

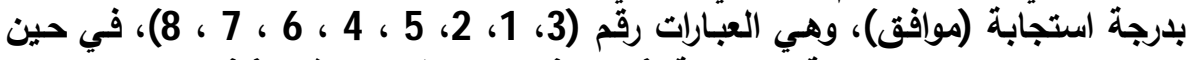

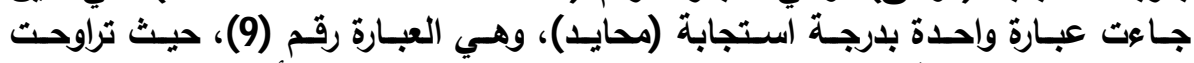

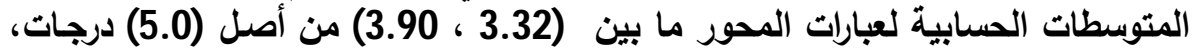

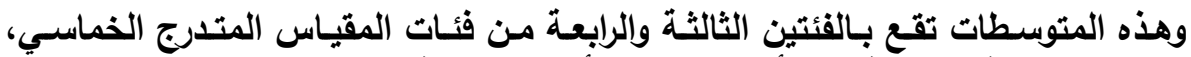

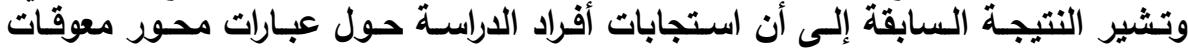

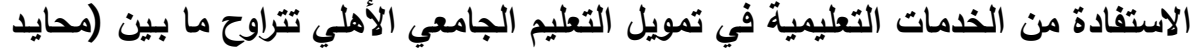

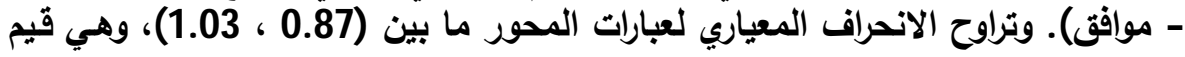


تتمحور حول الواحد الصحيح، وهذا يعكس تجانس استجابات أفراد الدراسة حول عبارات

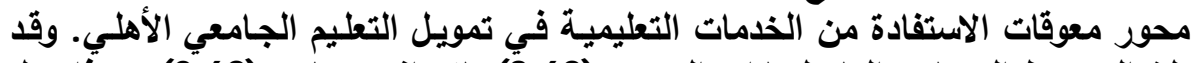

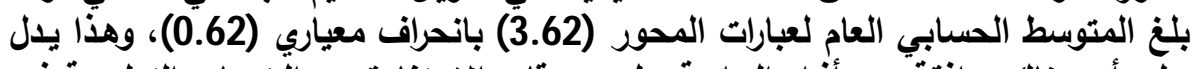

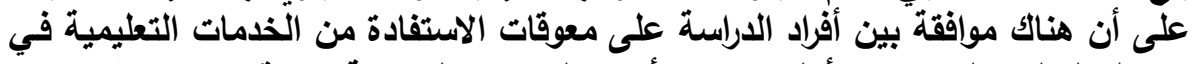

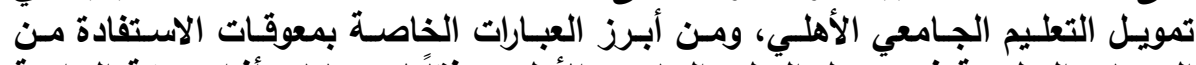

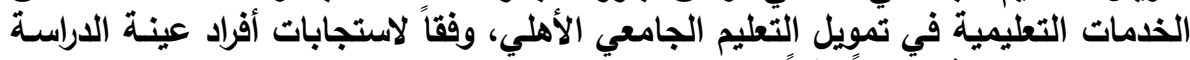

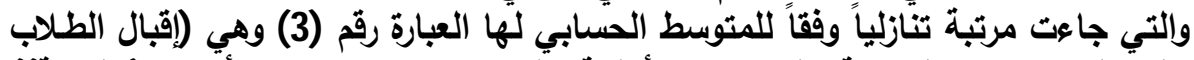

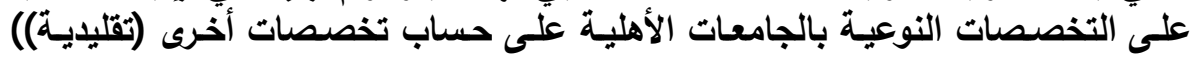

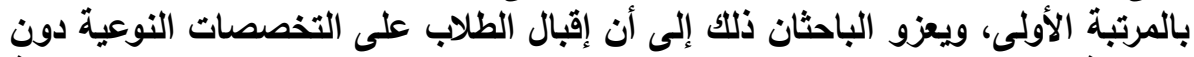

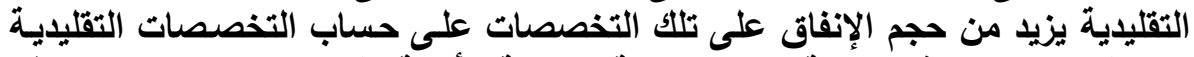

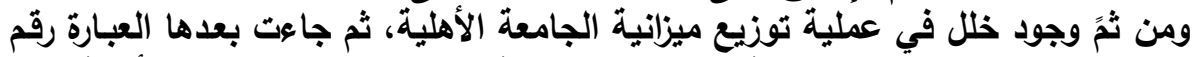

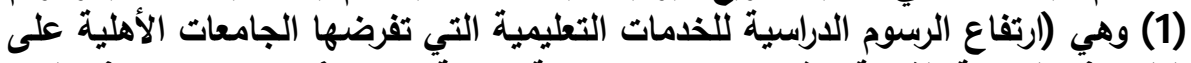

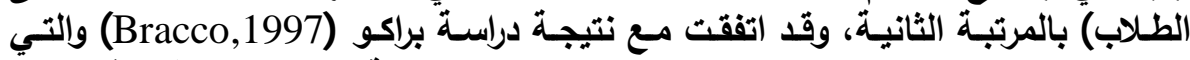

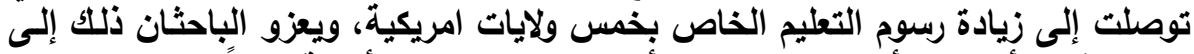

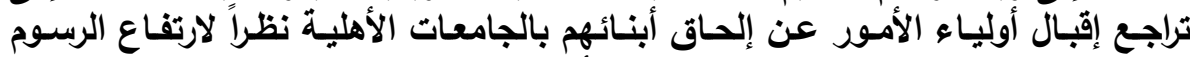

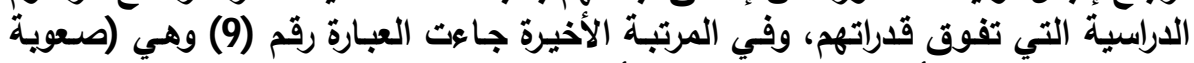

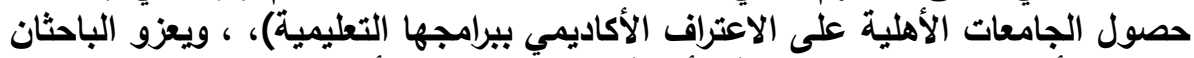

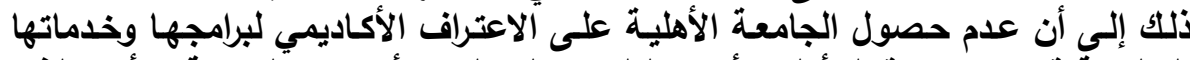

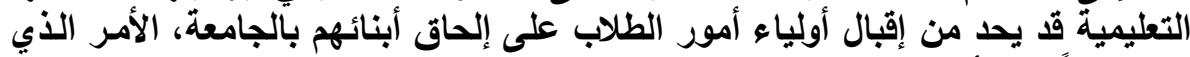
يؤثر سلباً على أعداد الطلاب بها.

2. المعوقات المتعلقة بمساهمة القطاع الخاص في تمويل التعليم الجامعي الأهلي.

جدول رقم (18) التكرارات والنسب المئوية والمتوسطات الحسابية والانحراف المعياري

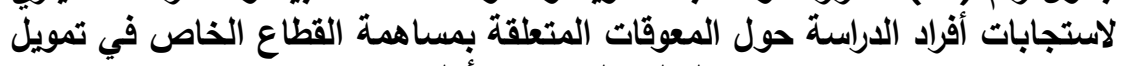
التعليم الجامعي الأهلي

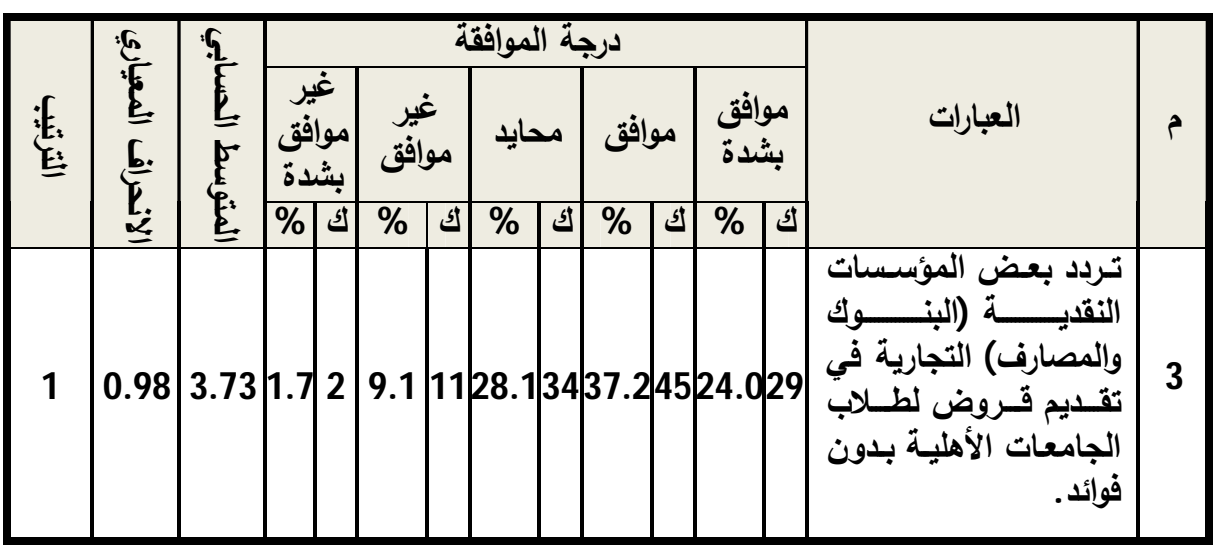

$-402-$ 
مجلة كلية التربية، جامعة الأزهر، العدد: (183، الجزء الثاني) يوليو لسنة 2019م

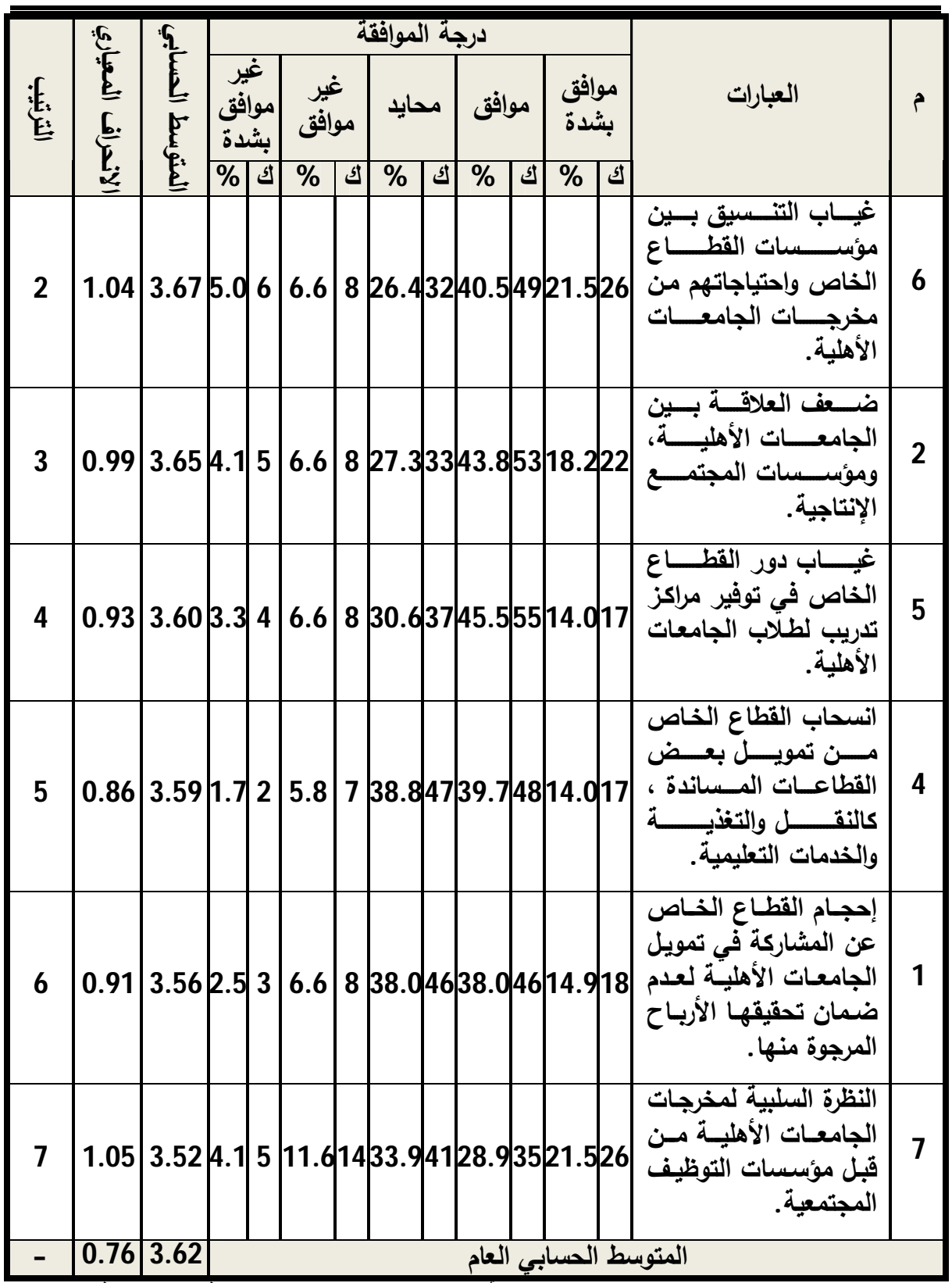

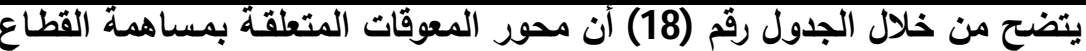

الخاص في تمويل التعليم الجامعي الأهلي يتكون من (7) عبارات، جاءت إنت جميعها بلدرجة

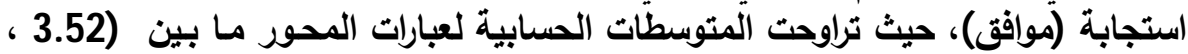

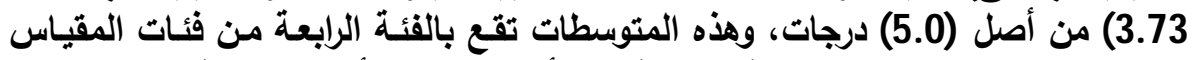

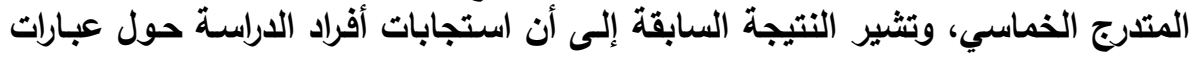


محور المعوقات المتعلقة بمساهمة القطاع الخـاص في تمويل التعليم الجـامعي الأهلـي

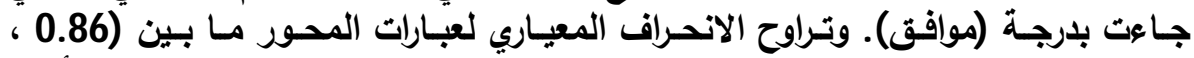

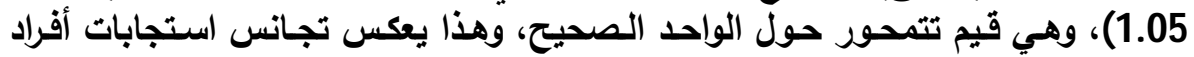

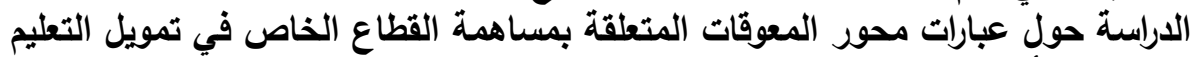

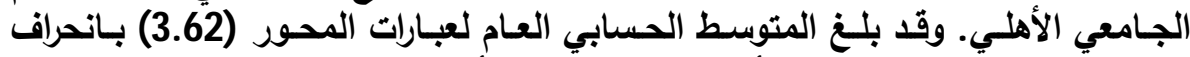

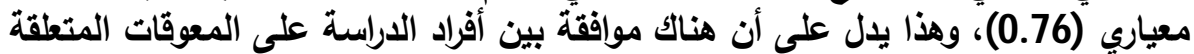

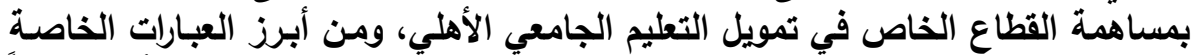

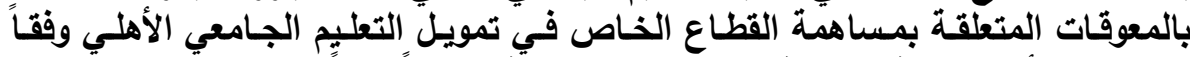

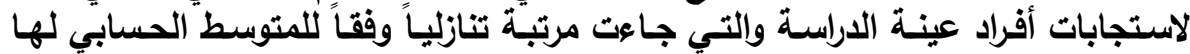

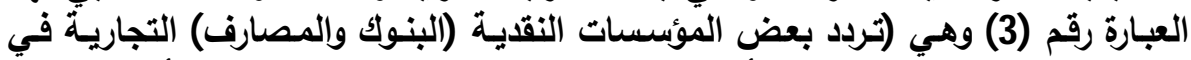

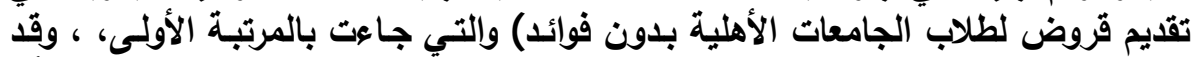

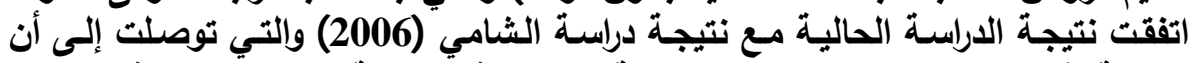

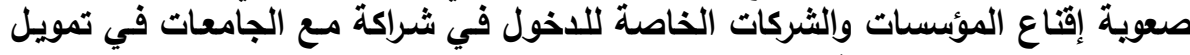

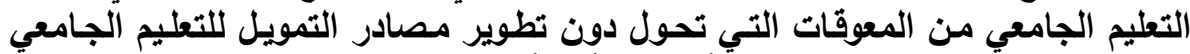

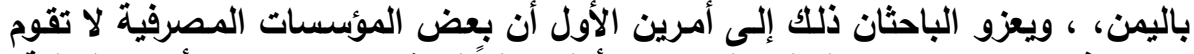

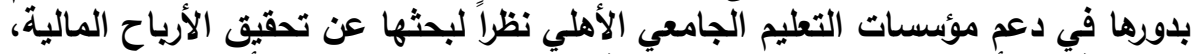

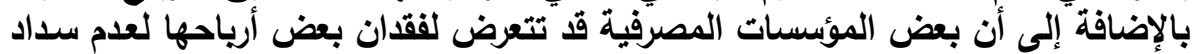

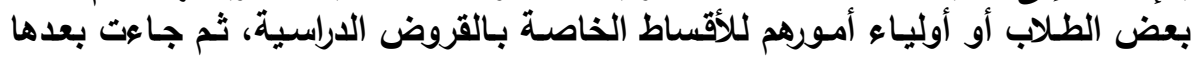

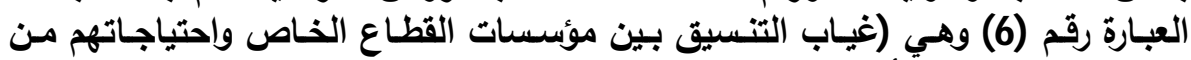

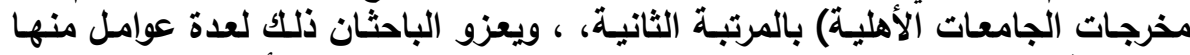

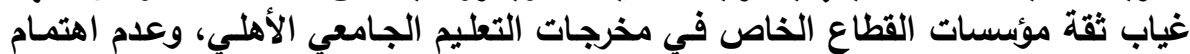

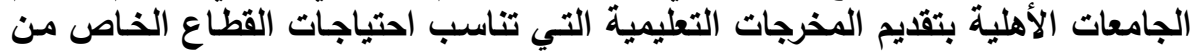

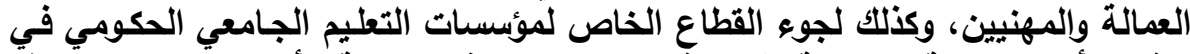

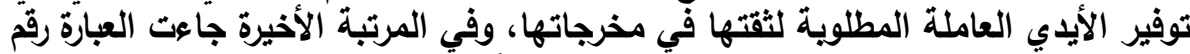

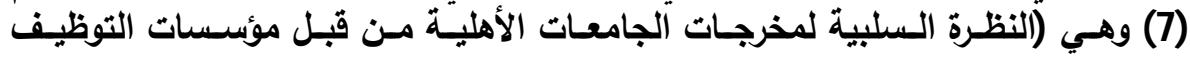

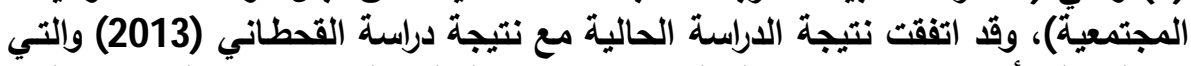

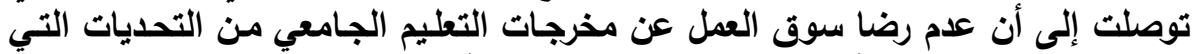

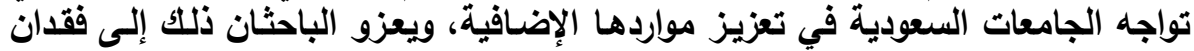

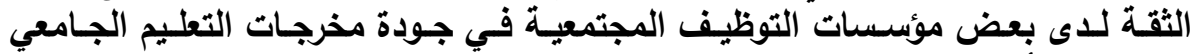

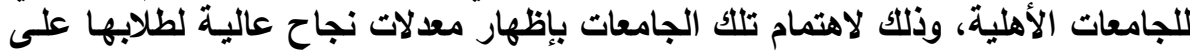


مجلة كلية التربية، جامعة الأزهر ، العدد: (183، الجزء الثاني) يوليو لسنة 2019م

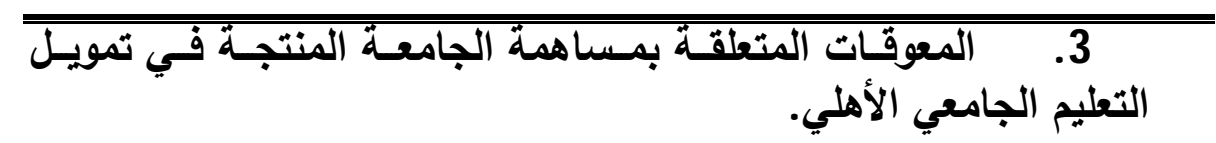

جدول رقم (19) التكرارات والنسب المئوية والمتوسطات الحسابية والانحراف المعياري لاستجابات أفراد الاراسة حول المكرات والسوقات المتعلقة بمساهمة الجامعة المنتجة في تمويل التعليم الجامعي الأهلي

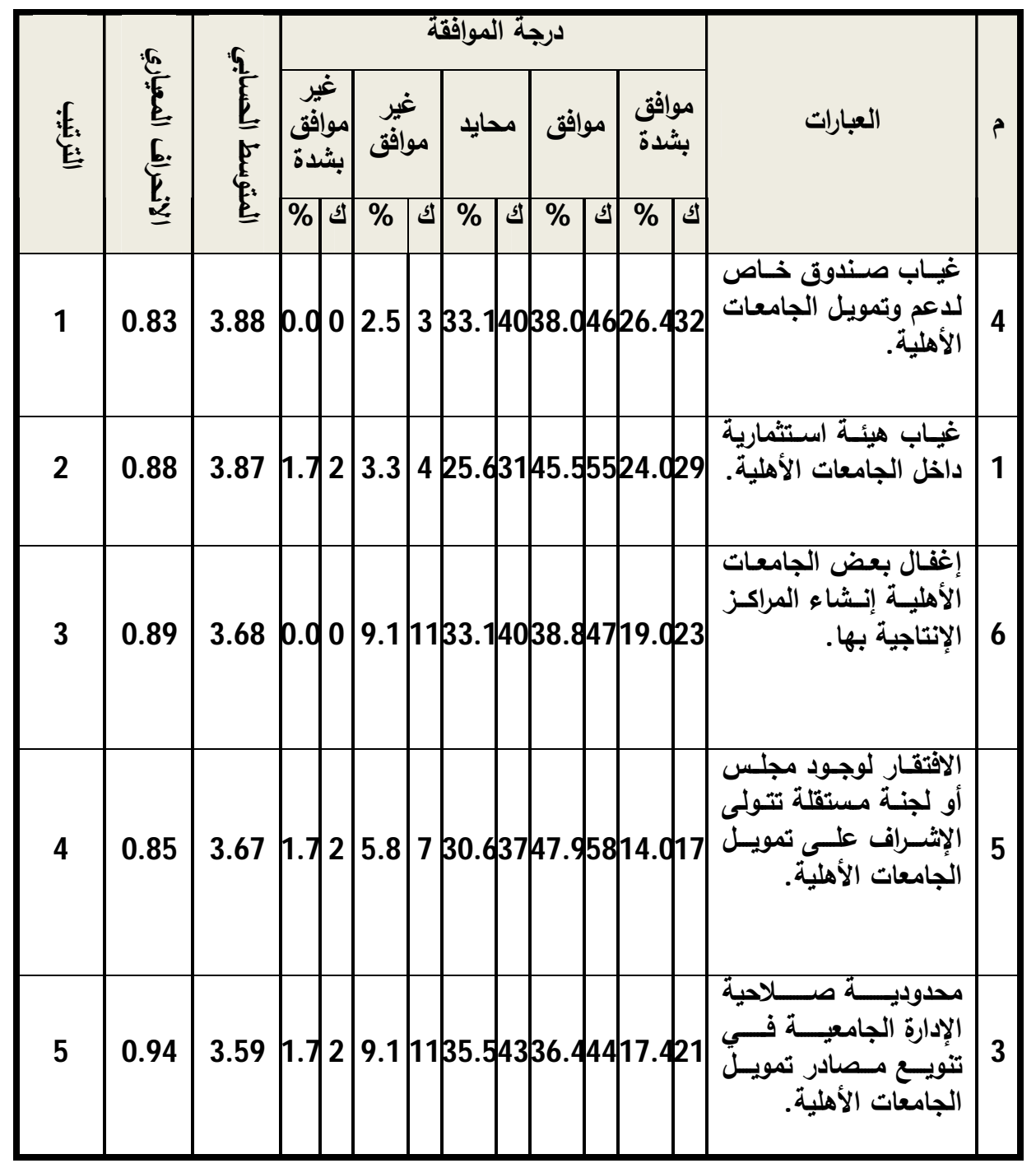




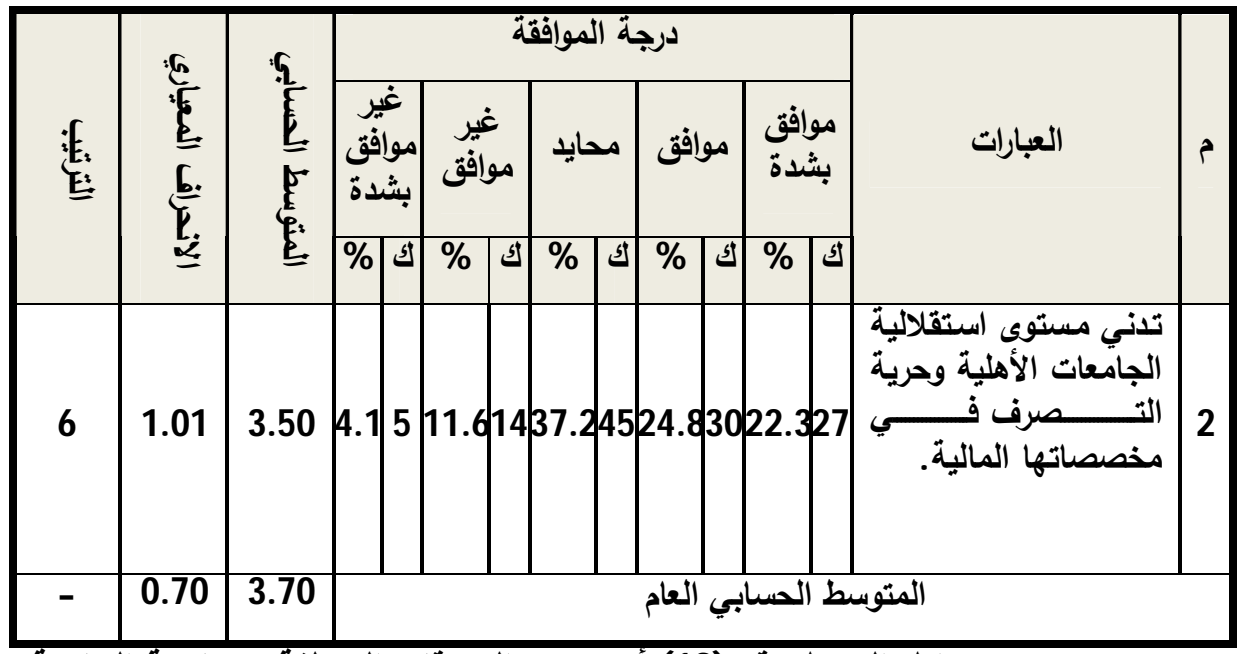

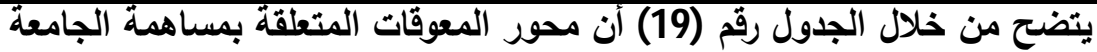

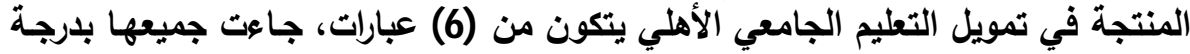

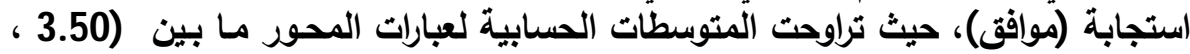

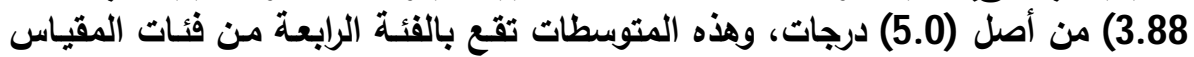

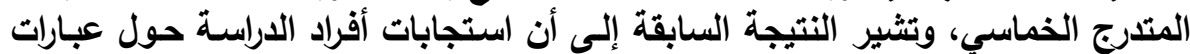

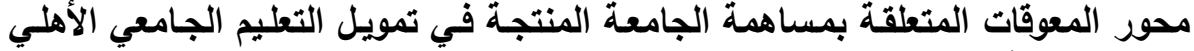

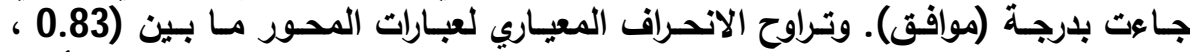

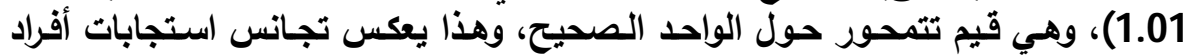

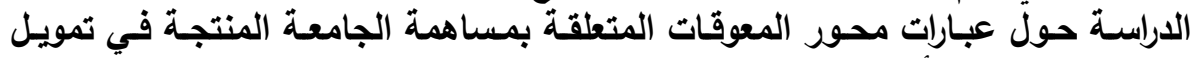

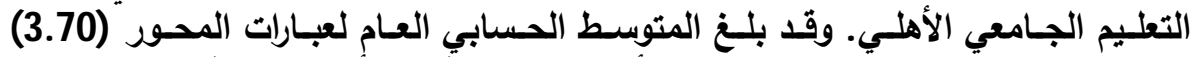

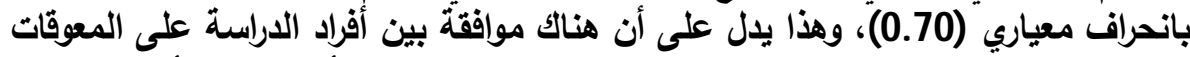

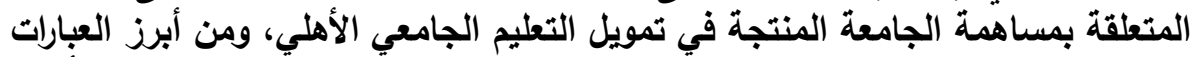

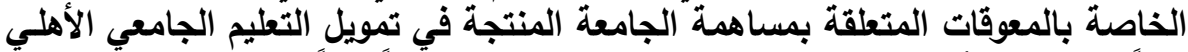

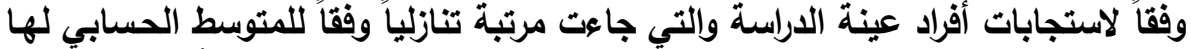

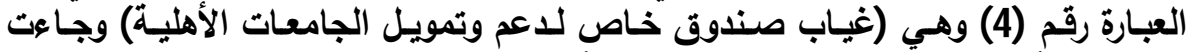

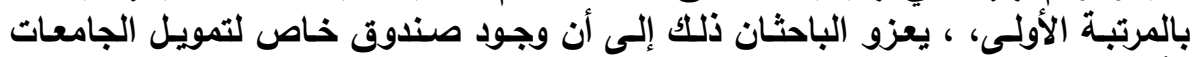

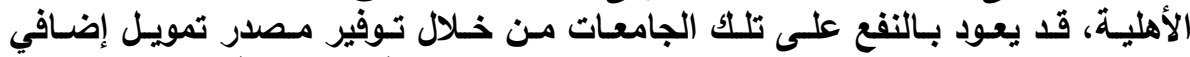

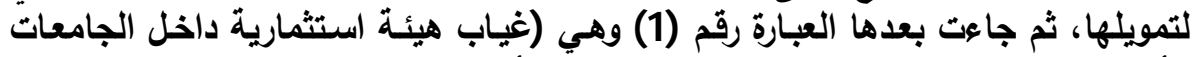

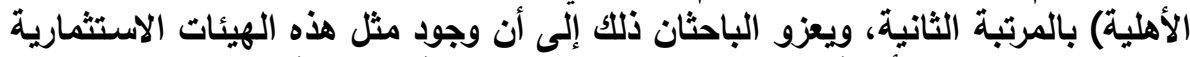

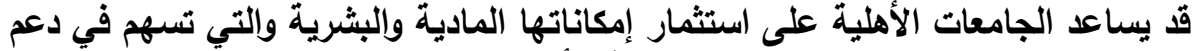

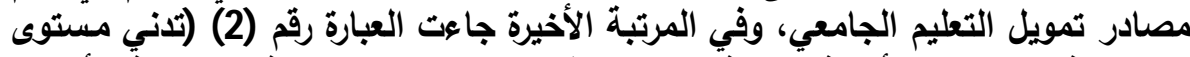

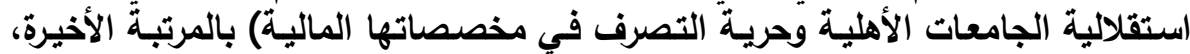

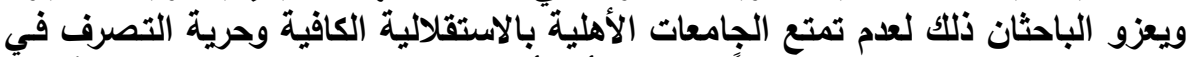

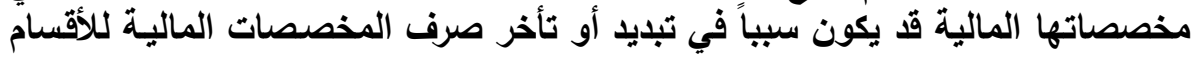


مجلة كلية التربية، جامعة الأزهر ، العدد: (183، الجزء الثاني) يوليو لسنة 2019م

\section{الأكاديمية والإداريةٌ.}

4. المعوقات المتعلقة بمساهمة الوقف والمساعدات الداخلية في تمويل التعليم الجامعي الأهلي.

جدول رقم (20) التكرارات والنسب المئوية والمتوسطات الحسابية والانحراف المعياري لاستجابات أفراد الدراسة حول المعوقات المتعلقة بمساهمة الموات الوقف والمساعدات المات الداخلية

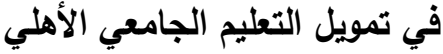

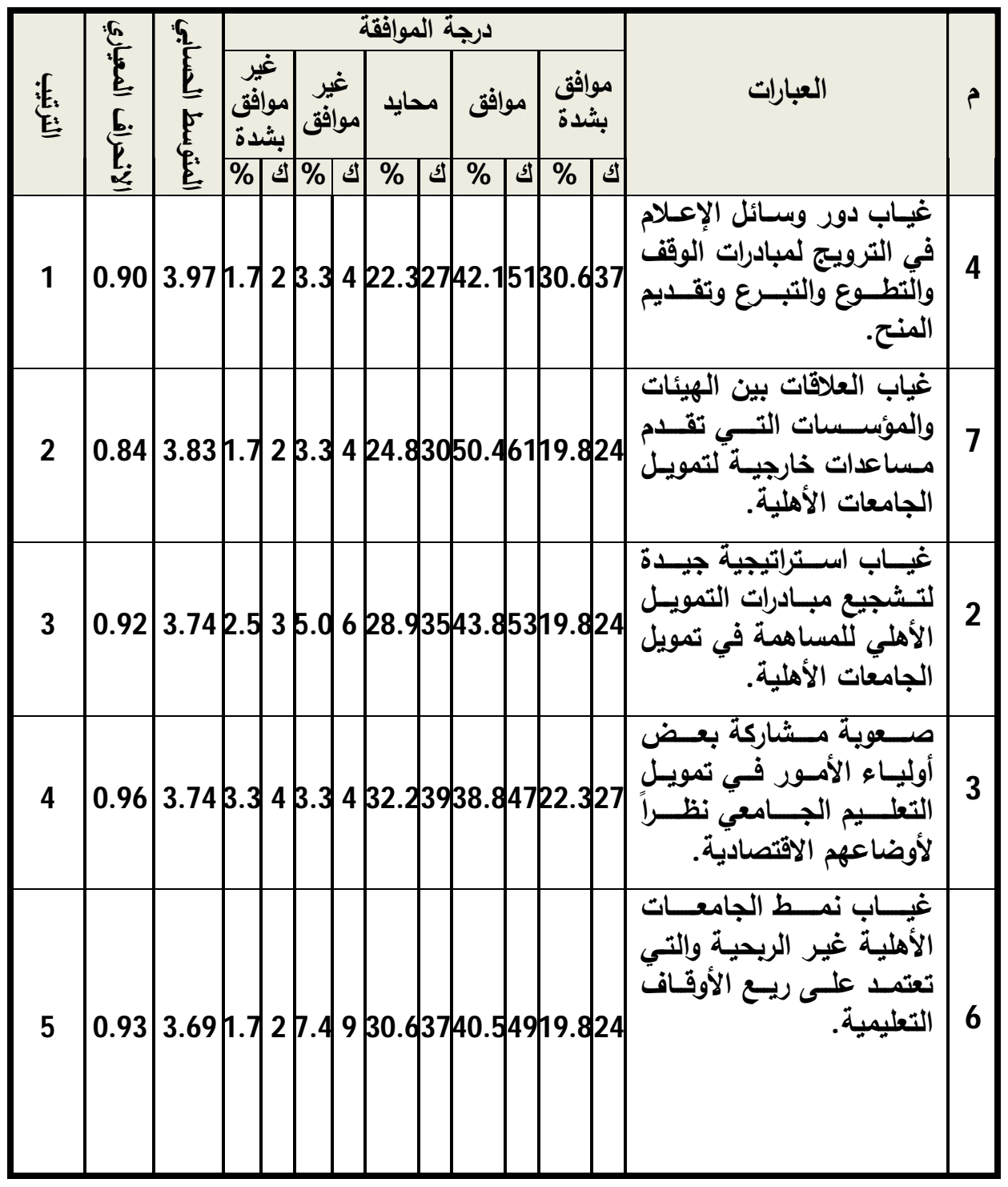


مجلة كلية التربية، جامعة الأزهر ، العدد: (183، الجزء الثاني) يوليو لسنة 2019م

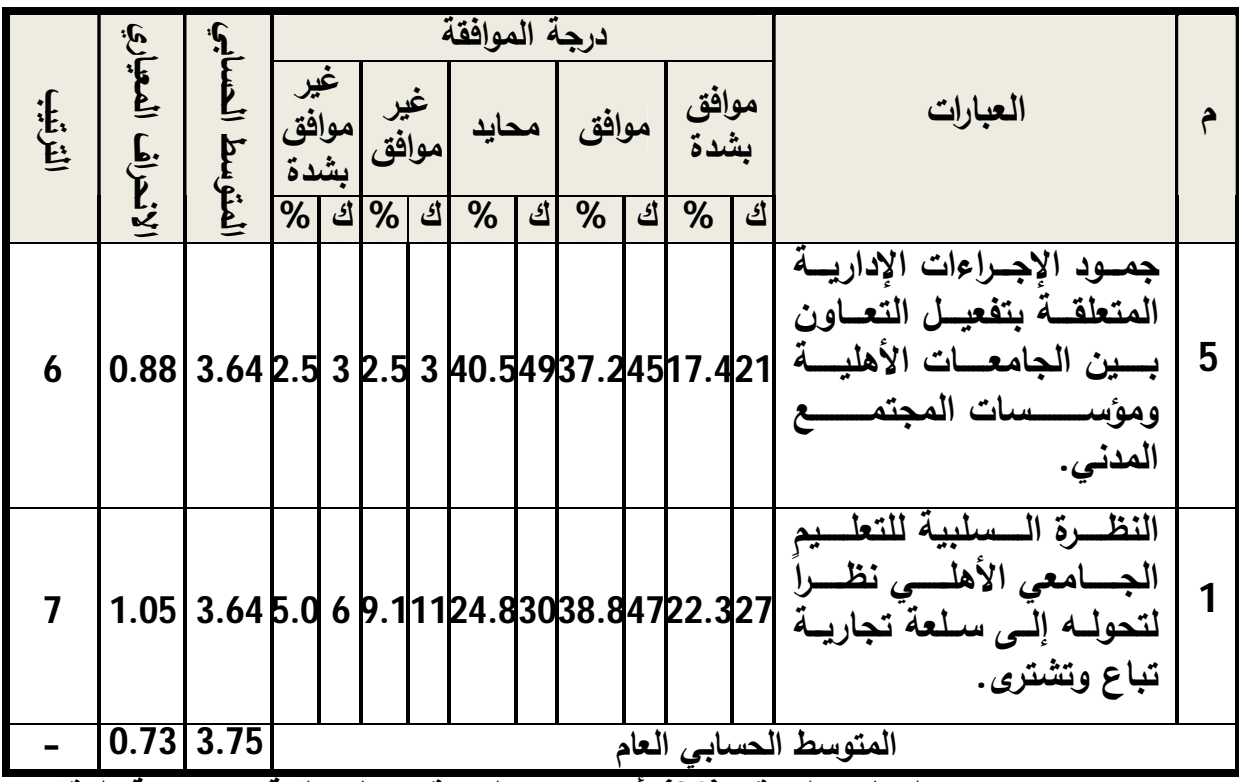

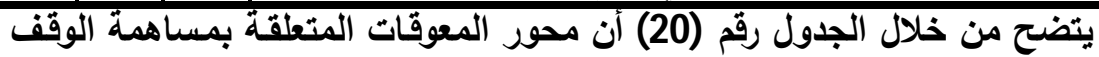

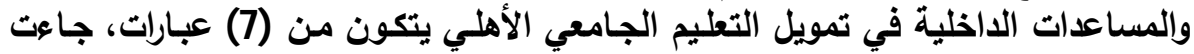

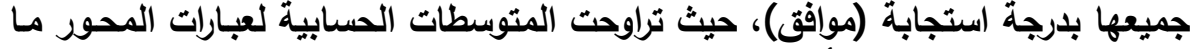

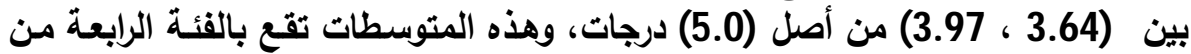

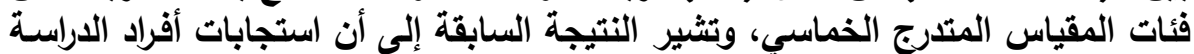

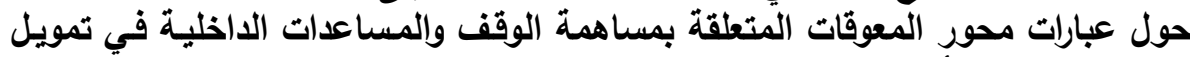

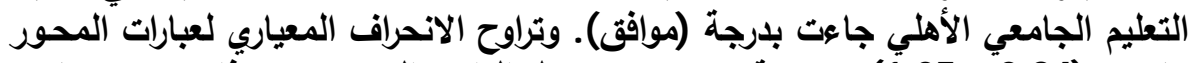

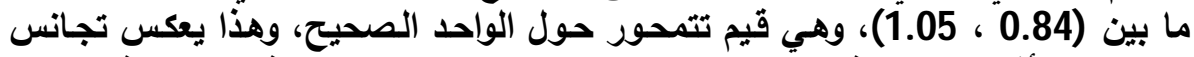

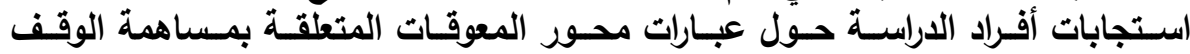

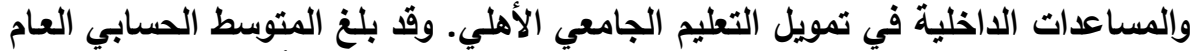

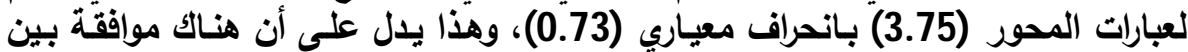

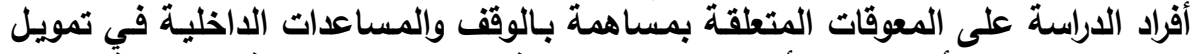

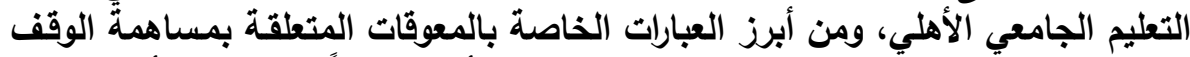

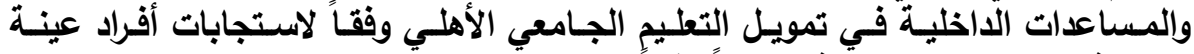

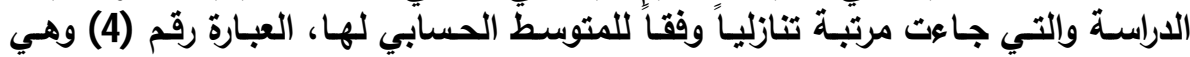

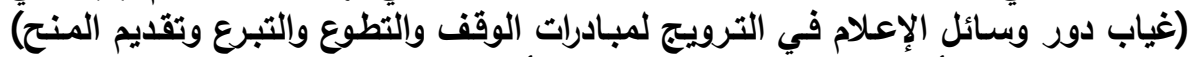

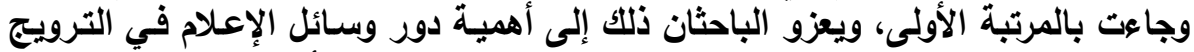

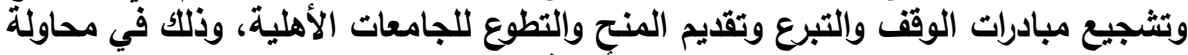

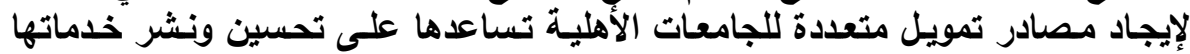

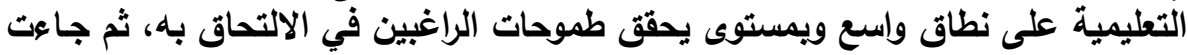

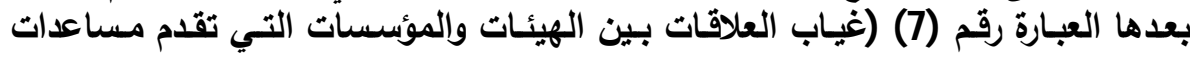


مجلة كلية التربية، جامعة الأزهر، العدد: (183، الجزء الثاني) يوليو لسنة 2019م

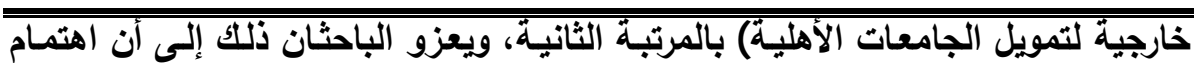

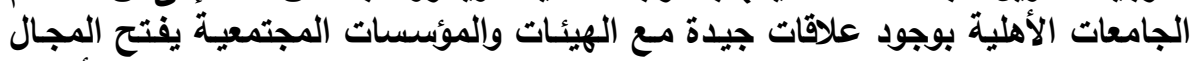

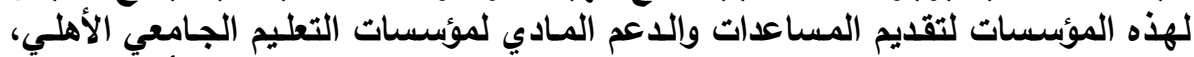

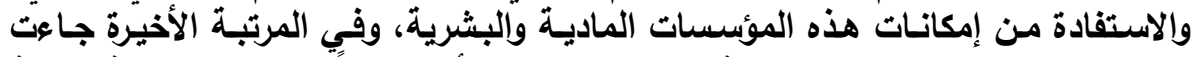

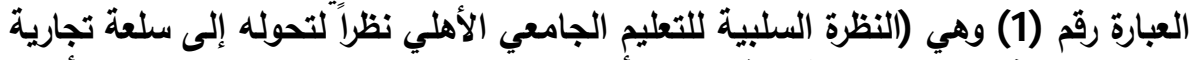

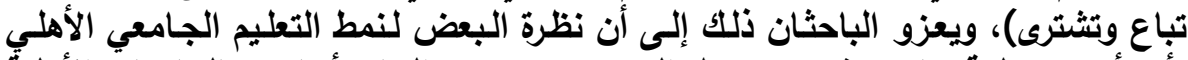

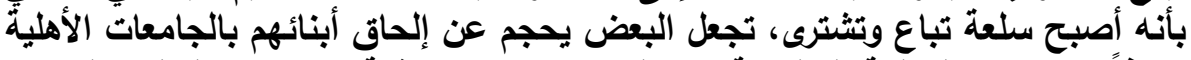

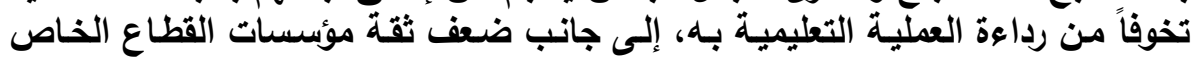
بمخرجاته.

نتائج الدراسة وتوصياتها:

\section{أولاً: نتائج الدراسة: توصلت الدراسة إلى العديد من النتائج، ومنها:}

1 - أن هناك حيادية بين الموافقة والرفض بين أفراد الدراسة حول واقئ واقع تمويل الجامعات

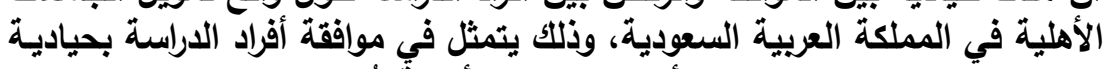

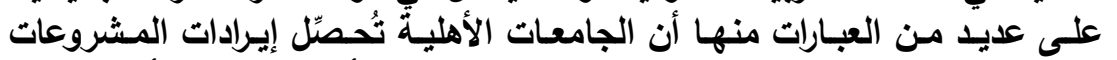

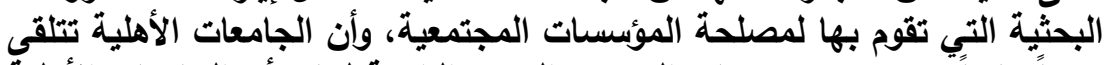

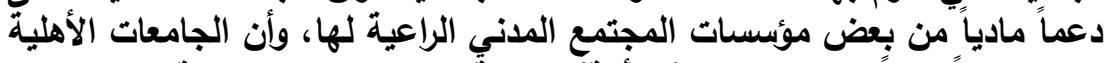

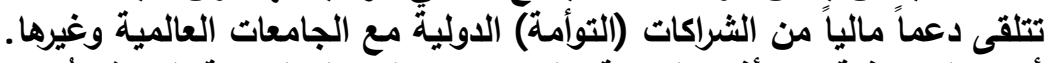

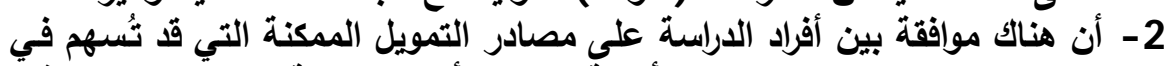

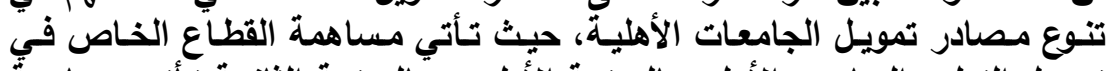

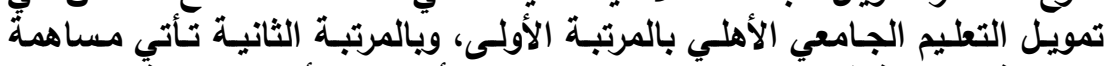

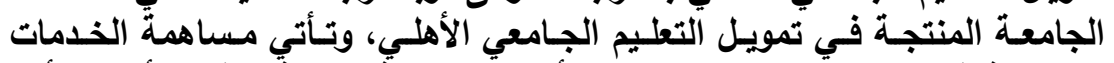

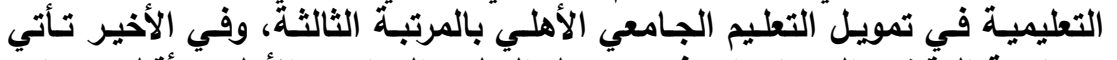

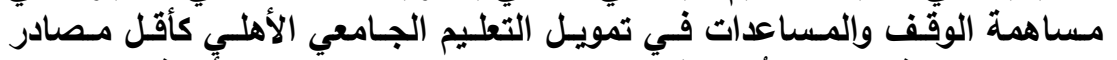

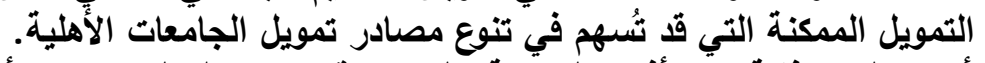

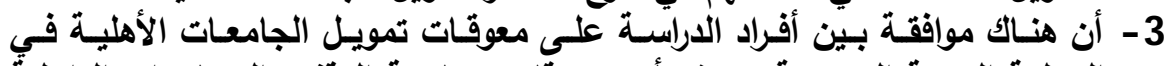

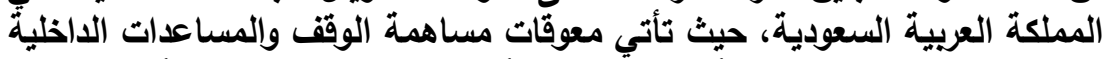

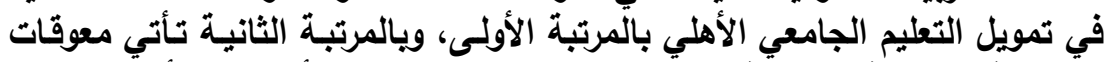

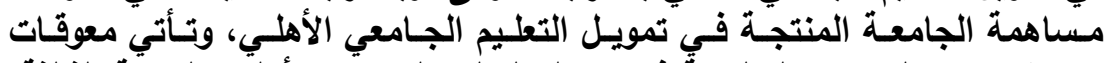

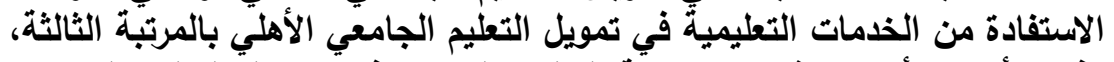

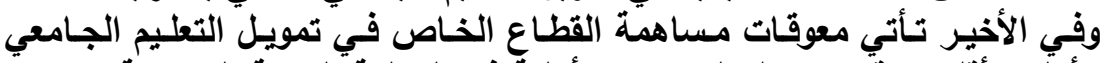

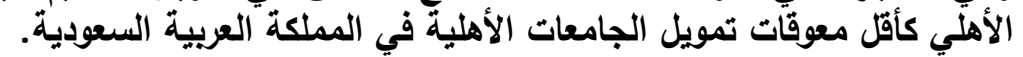




\section{ثانياً: توصيات الاراسة}

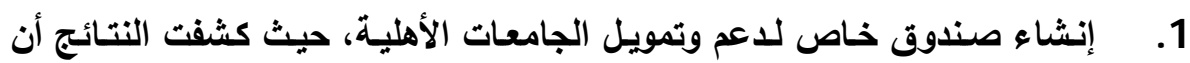

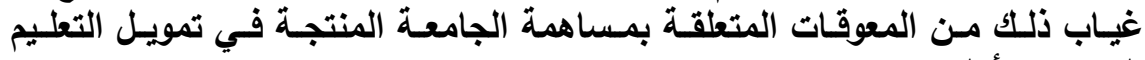

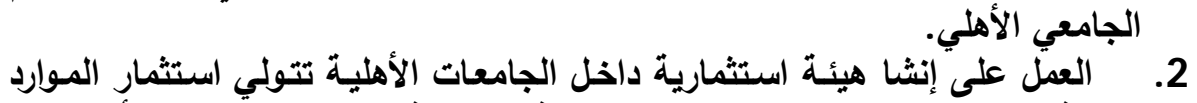

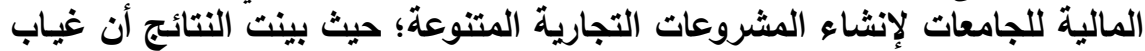

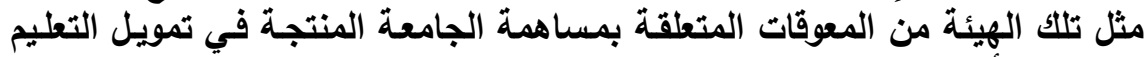

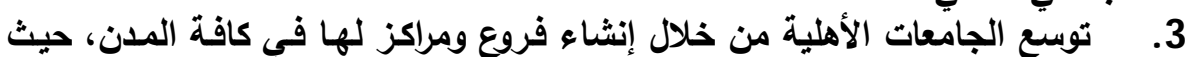

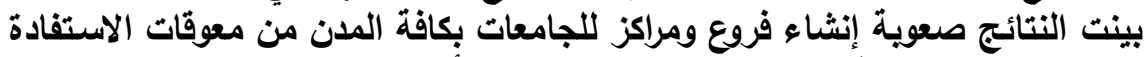

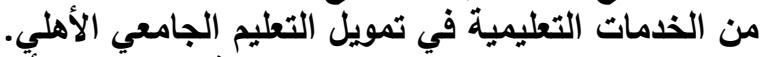

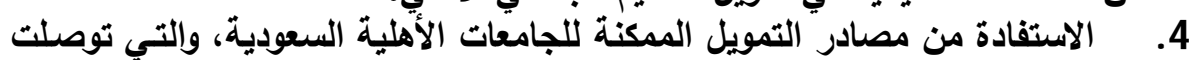

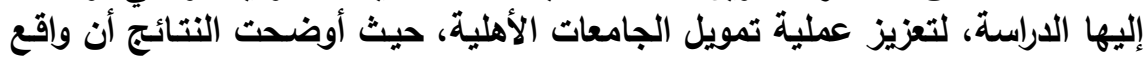

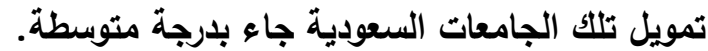

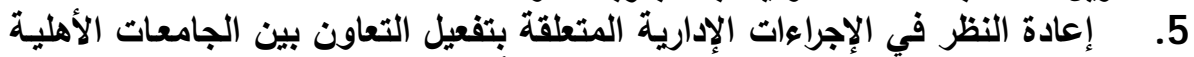

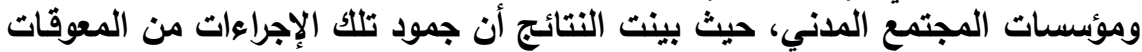
المتعلقة بمساهمة الوقف وإلمساعدات الداخلية في التمويل. 


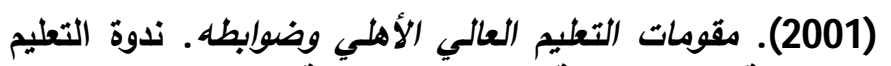

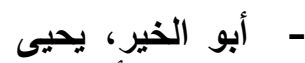

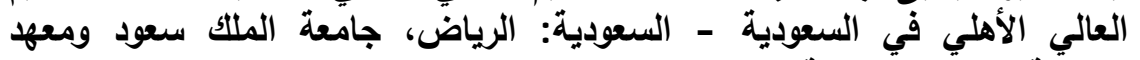
العالمية للحاسب والتقنية، 15 -48.

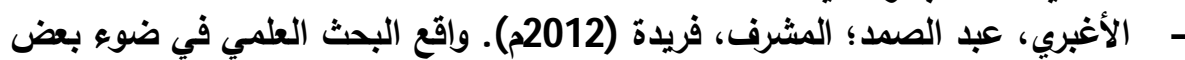

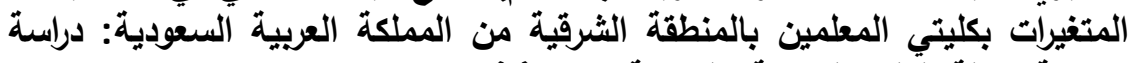

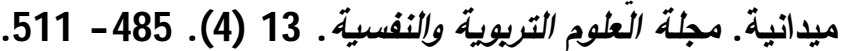

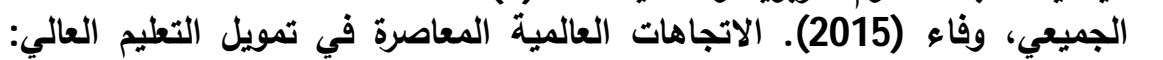

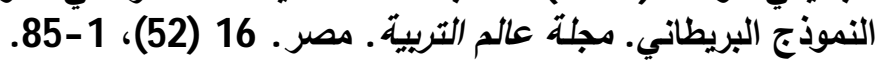

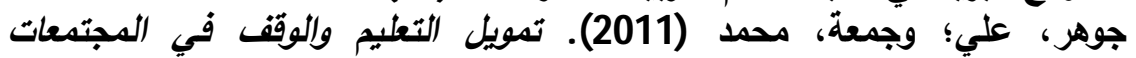
الإسلامية "روئية اقتصادية تريوية"، القاهرة: المكتبة العصرية للنشر والتوزيع.

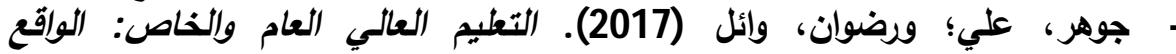
والتحديات ـ ألمنصورة: المكتبة العصرية للنشر والتوزيع.

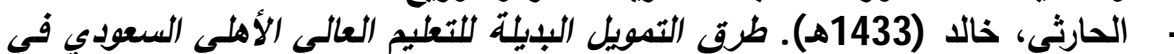

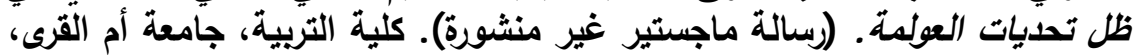

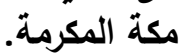

حامد، محمد؛ وزيدان، همام؛ والبحيري، السيد (2008). تمويل التعليم الجامعي واتجاهاته المعاصرة ـ القاهرة: عالم الكتب.

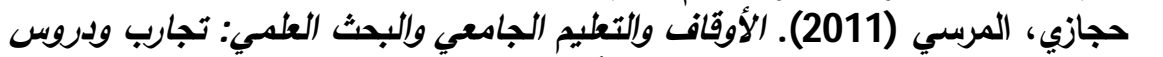

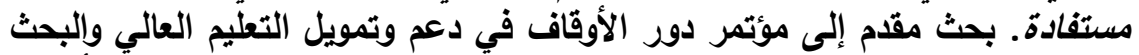

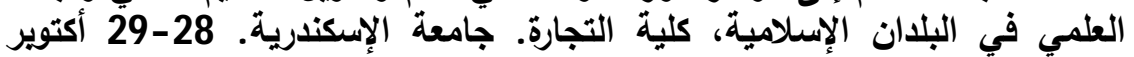

- الحريى، عبدالله (2009) . العوامل والقوى المرتبطة بإنشاء مؤسسات التعليم العالي

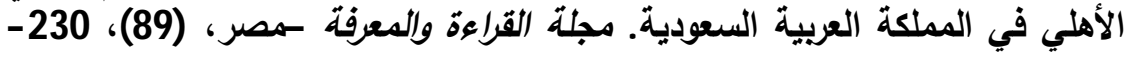

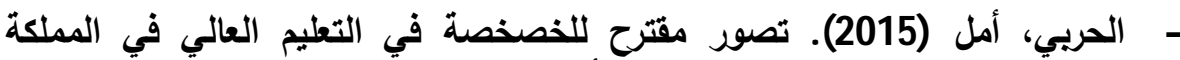

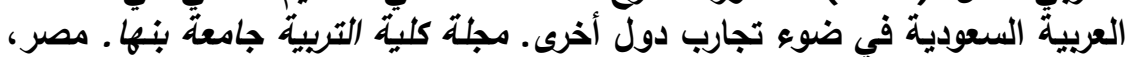

.302- 27 (106)، 205

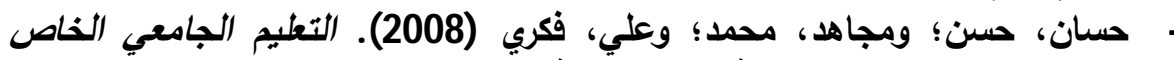

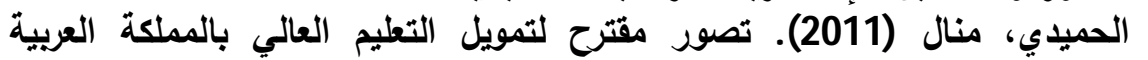

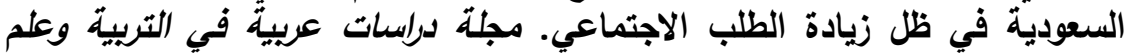

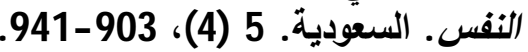

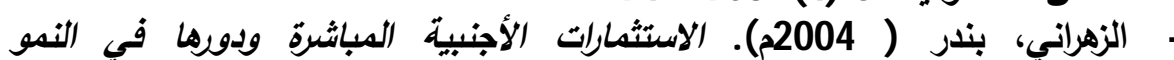

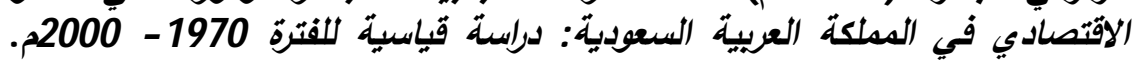

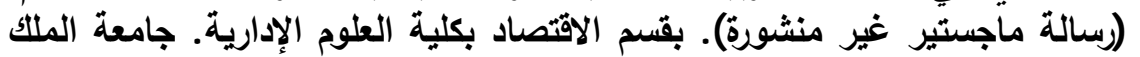

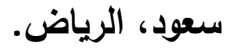


- الفاعوري، رفعت (2004م). تجابب عربية في الخصغصة. القاهرة: منشورات المنظمة العربية للتنمية الإدارية.

- زمان، حسام (2014)، خيارات مقابلة الطلب على التعليم العالي في العارئية المملكة العربية

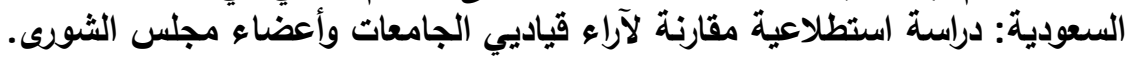

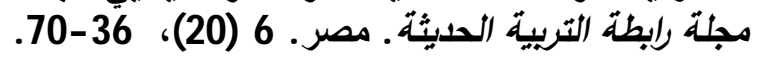

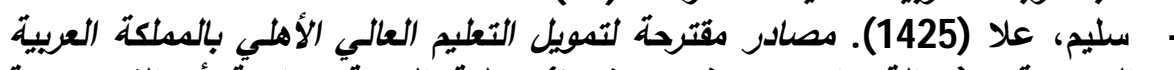

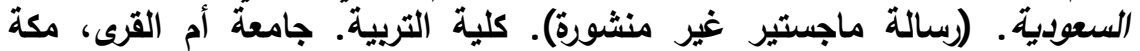

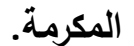

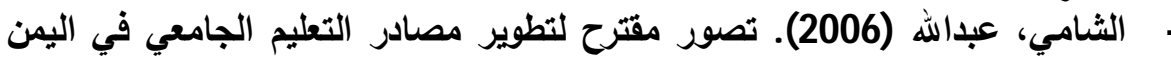

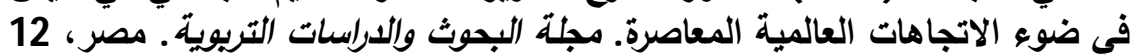

- الثدادي، عبد الله (1427هـ). التعليم الجامعي الأهلي: أهميته ، تخطيطه ، ضوابطه .

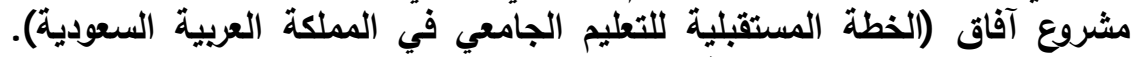

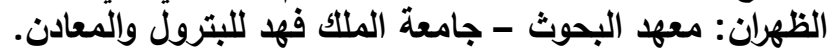

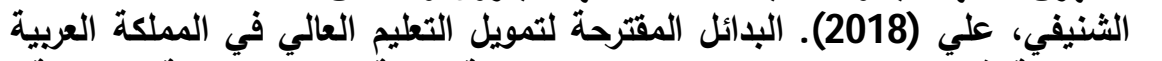

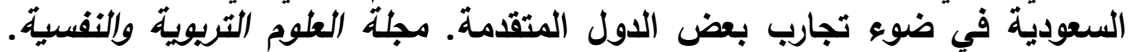
فلسطين، 2 (10)، 70 - 100.

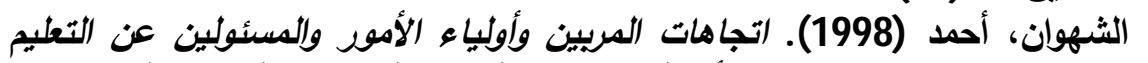

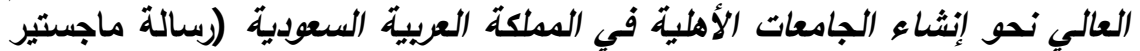
غير منشورة) ، كلية التربية، جامعة الملك سعود التهات السعودية.

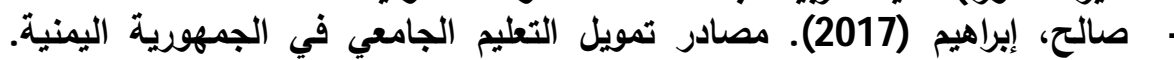
مجلة كلية التتربية في العلوم التريوية ، مصر ، 41 (32017)، 14 -48.

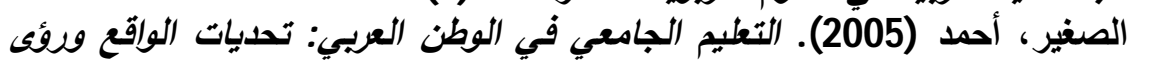

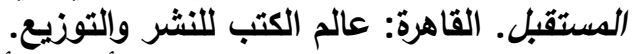

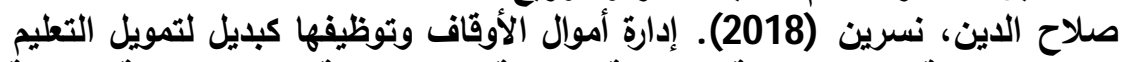

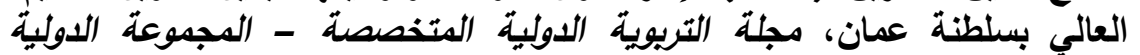

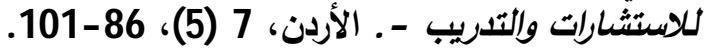

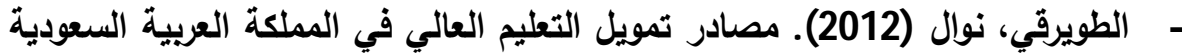

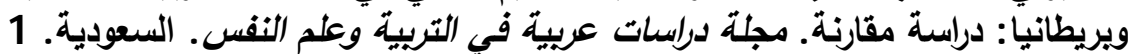
.287- 263 ، 24 (24) عبدالجليل، مصطفى (2013). خيارات تمويل التعليم العالي في السودان. مجلة

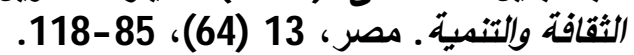
عبدريه، صابر (2013). التمويل (الذاتسي للتعليم الجامعي. القاهرة: مؤسسة طيبة للنشر والتوزيع. فئ. - العتيبي، فهـ (1425هـ). إسهام القطاع الخاص في تمويل التعليم العام بالمملكة

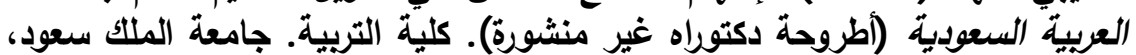

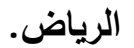


مجلة كلية التربية، جامعة الأزهر، العدد: (183، الجزء الثاني) يوليو لسنة 2019م

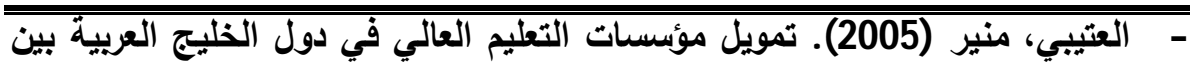

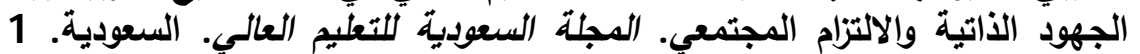

.98- 37 ، (2)

عزوز، رفعت؛ وعامر، طارق (2009). اقتصاديات وتمويل التعليم. القاهرة: مؤسسة

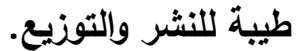

عمارة، هشام (2012). دور المجتمع الأهلي في دعم وتمويل التعليم العالي والبحث

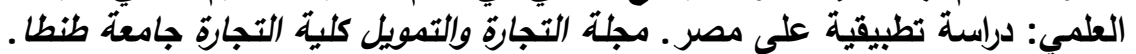
مصر . (2)، 329 -384. 329.

عون، وفاء (2001)، تصور مقترح لنمط تمويل التعليم العالي الأهلي السعودي.

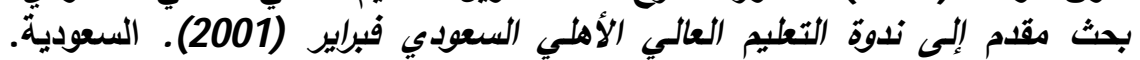

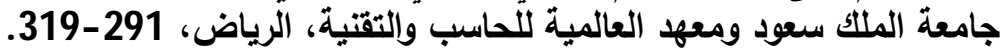

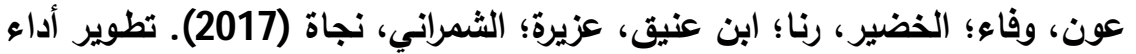

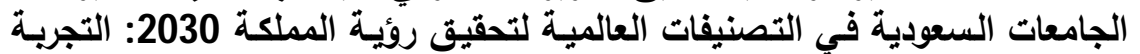

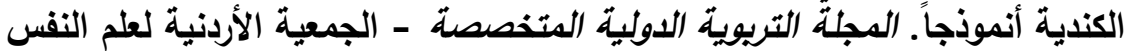

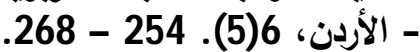

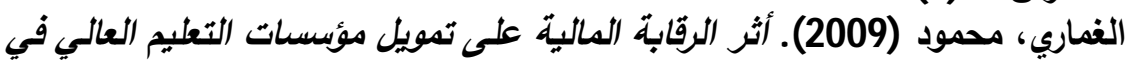

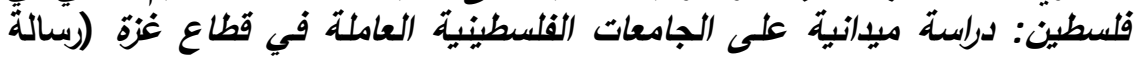

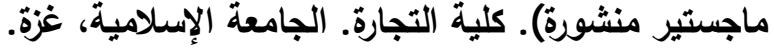

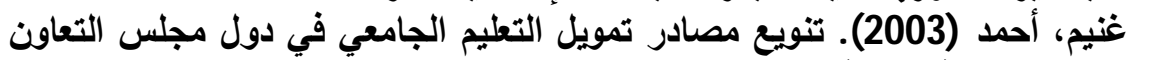

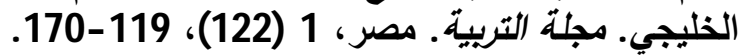
- الفاعوري، رفعت (2004م). تجارب عربية في الخصغصة. القاهرة: منشورات (الفية المنظمة العربية للتنمية الإدارية.

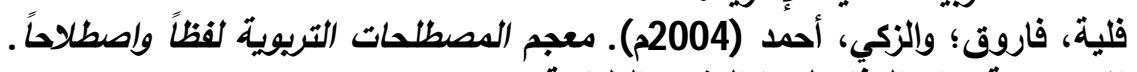

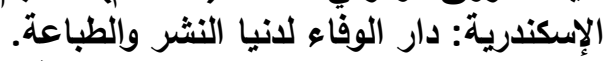

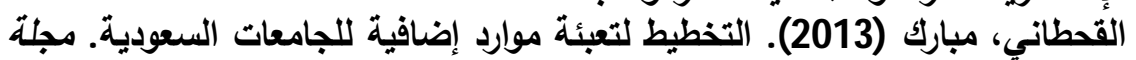

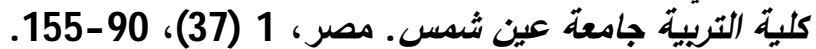

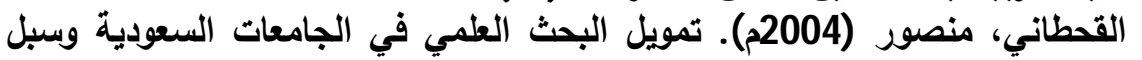

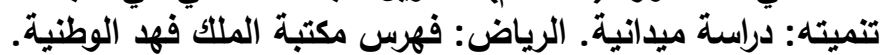

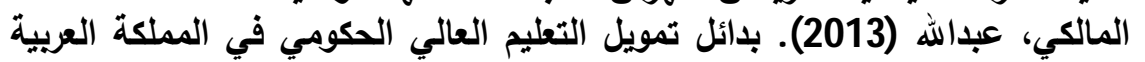

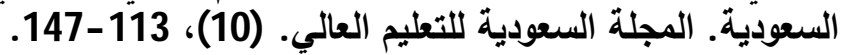
مريزيق، هشام؛ الفقيه، فاطمة (2008). قضايا معاصرة في التعليم الجامعي. عمان: دار الراية للنشر والتوزيع.

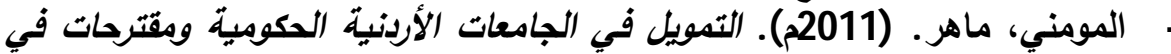

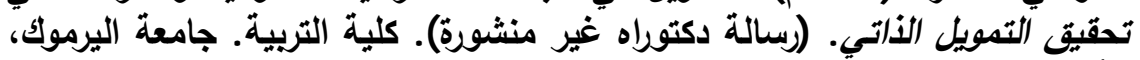

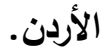




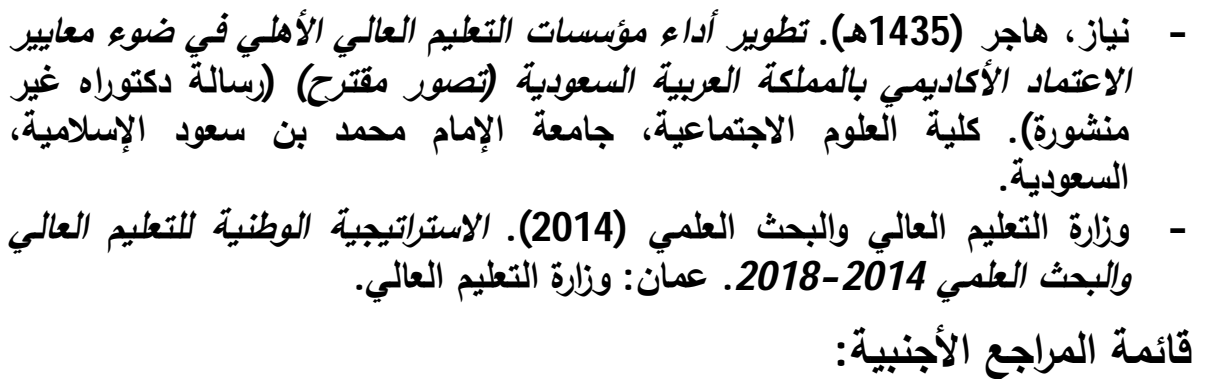

- Council on Higher Education (2018). What is the difference between a public and private higher education provider?. Retrieved at 26/7/2018, from http://www.che.ac.za/content/what-difference-between-publicand-private-higher-education-provider.

- Dominicis, L., Pérez, S. \&Zubieta, A. (2011). European University Funding and Financial Autonomy, JRC Scientific and Technical Reports, 1-30.

- Bracco, kathy (1997). Public and private financing of higher education: shaping public policy for the future. American council on education Oryx press series on higher education, https://www.amazon.com/Public-Private-Financing-HigherEducation/dp/1573561169.

- Harvard University (2015).Financial Report Fiscal Year 2015, 1-50.

- http://www.wg.aegee.org/ewg/higheredu.htm.

- Oxford University Gazette.(2011).University Mission Statement and Strategic Plan, Supplement (2). 4945.

- Sav, T (2013). Four-stage DEA ef Ficiency Evaluations, Financial Reforms Public University Funding International Journal of Economics and Finance, 5 (1), P P 24-36.

- Talk, Chalk (2007). discrimination in education: public versus private universities. Journal of law \& education, 2(36). 
قائمة المواقع الإكترونية:

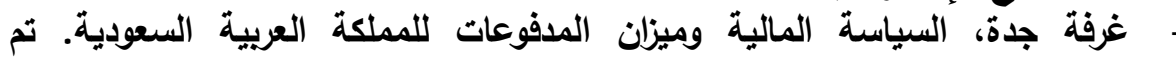

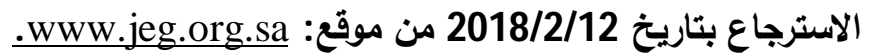

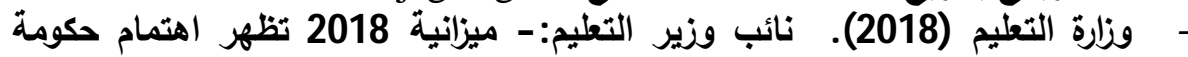

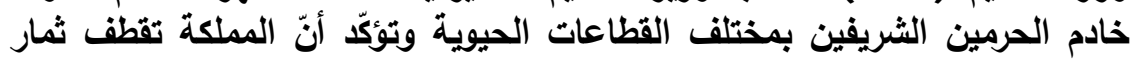

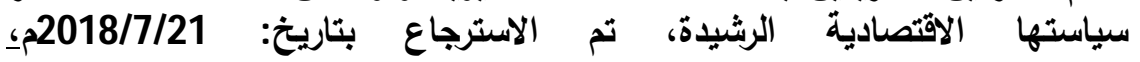
.https://www.moe.gov.sa

وزارة التعليم (2018). الإدارة العامة للتعليم العالبي الأهلي، تم الاسترجاع بتاريخ .https://departments.moe.gov ،2018/12/1 - مزارة التعليم (2018). علاقة الكليات والجامعات الأهلية بوزارة التعليم، تم الاسترجاع

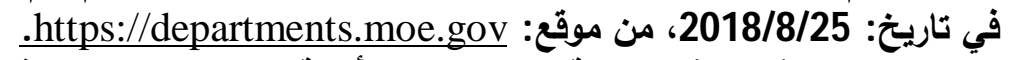

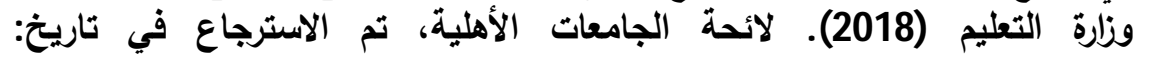

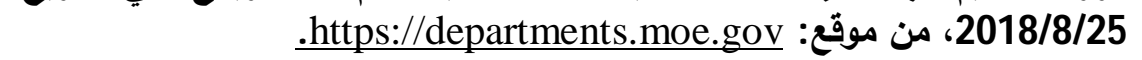
وزارة التعليم (2018). إحصاءات التعليم العالي، تم الاسترجاع بتاريخ: ـ. https://departments.moe.gov.sa ،2018/7/26 